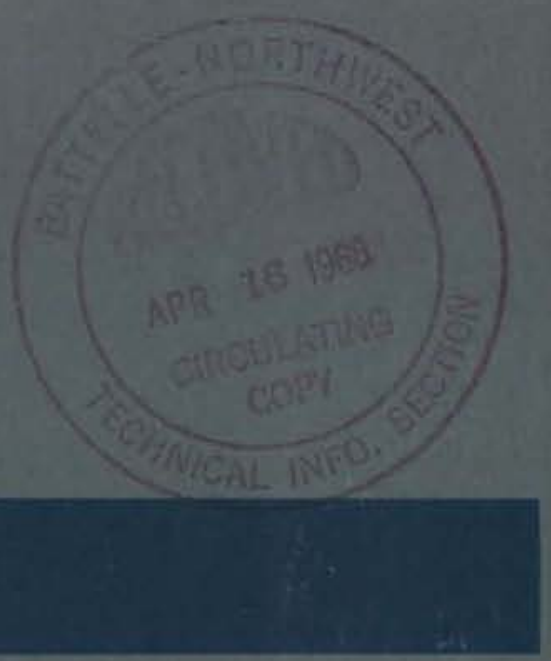

\title{
COMPARISONS OF THE CONTAINMENT BEHAVIOR OF A SIMULANT WITH FISSION PRODUCTS RELEASED FROM IRRADIATED $\mathrm{UO}_{2}$
}

R. K. HILLIARD

L. F. COLEMAN

J. D. MCCORMACK

MARCH, 1968

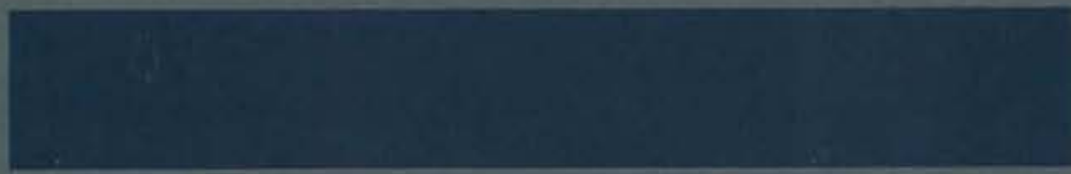

\section{AEC RESEARCH \& DEVELOPMENT REPORT}

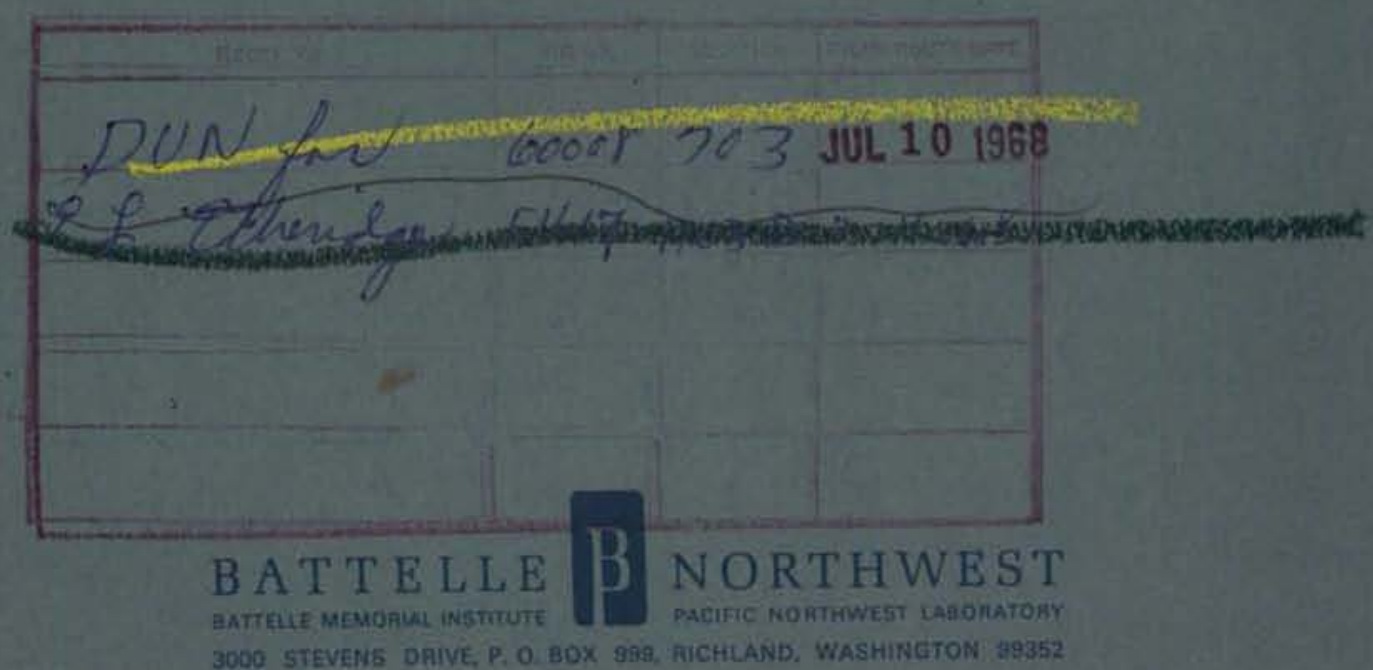




\title{
33679000606998
}

\author{
BNWL - 581 \\ UC-80, Reactor Technology
}

\section{COMPARISONS OF THE CONTAINMENT BEHAVIOR OF \\ A SIMULANT WITH FISSION PRODUCTS \\ RELEASED FROM IRRADIATED $\mathrm{UO}_{2}$}

\section{By}

\author{
R. K. Hilliard \\ L. F. Coleman \\ J. D. McCormack \\ Reactor Engineering Section \\ Engineering Development Department
}

March 1968

FRST UNRESTRICTED

distribution made APR 8168

\author{
PACIFIC NORTHWEST LABORATORY \\ RICHLAND, WASH INGTON
}


BNWL - 581

Printed in the United States of America Available from

Clearinghouse for Federal Scientific and Technical Information National Bureau of Standards, U.S. Department of Commerce Springfield, Virginia 22151

Price: Printed Copy $\$ 3.00 ;$ Microfiche $\$ 0.65$ 


\author{
COMPARISONS OF THE CONTAINMENT BEHAVIOR OF \\ A SIMULANT WITH FISSION PRODUCTS \\ RELEASED FROM IRRADIATED $\mathrm{UO}_{2}$ \\ R. K. Hilliard \\ L. F. Coleman \\ J. D. McCormack
}

ABSTRACT

Experiments were performed in which either simulant aerosols or fission products released from heated trace-irradiated $\mathrm{UO}_{2}$ were released into small vessels containing condensing steamair atmospheres. The behavior of the two different types of aerosol materials was characterized and compared with each other and with transport theory. The conclusion was made that the simulant aerosol developed for the Containment Systems Experiment (CSE) is a fully satisfactory substitute for real fission products in containment transport tests investigating removal by natural processes. 


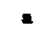




\section{$\underline{\text { TABLE OF } \text { CONTENTS }}$}

LIST OF FIGURES. • • • • • • • • • • • • • V V LIST OF TABLES • • • • • • • • • • • • v viii

I. INTRODUCTION . • • • • • • • • • • • • • • • •

II. SUMMARY AND CONCLUSIONS • • • • • • • • • • • • •

III . THEORETICAL CONSIDERATIONS • • • • • • • • • • • 5

Mathematical Models. . . . . . . . . . 6

Diffusional Models . • • • . • • • . . 6

We11 Mixed Models. • • • • • • • • . • 7

Estimation of Mass Transfer Coefficients. . . . 16

IV. EXPERIMENTAL CONDITIONS • • • • • • • • • • • • • • 21

Experiment Structure • • • • • • • • • • 21

Experimental Equipment. • • • • • • • • • 22

Test Conditions . • . . • • • • • • . 26

Irradiated Source Tests. . • • • • • . 26

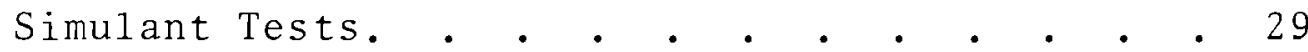

Methods of Sample Analysis . . . . . . . . 30

V. RESULTS AND DISCUSSION $\quad$ •

Source Term • • • • • • • • • • • • • • 31

Irradiated Source Tests. • • • • • • • • 32

Simulant Tests. • • • • • • • • • • • 34

Changes in Gas Phase . . . . . • . • . 37

Maypack Sample Interpretation. • • • • • . 38

Gas Concentration Time Dependence • • • • • 39

Iodine Form in Containment. . . . • . . 40

Mass Transfer Coefficients. • • • • • • . 40

Gas-Liquid Equilibrium . • • • • • • • • 42

Distribution Within Containment. . • . . • . 44

Form in Condensate . • . • • • • • • • . 47

Overall Material Recovery. • • • • • • • • • 49

Miscellaneous Observations • • • • • • • • 50

Effect of Mass Concentration . • . • • • • 50

Effect of Aerosol Complexity . • • • • • • 50 


\section{TABLE OF CONTENTS (contd)}

Effect of $\mathrm{UO}_{2} \mathrm{Cladding}$ Material . . . . . 51

Fresh Versus Aged Paint . . . . . . . 51

Sampling Through Long Lines. . . . . . . 52

Effect of Agitation . . . . . . . . . 52

VI. ACKNOWLEDGEMENTS. • • . • • • • . • • • • . 55

VII. NOMENCLATURE • • • • • • • • • • • • • • • • 56

VIII. REFERENCES. • • • • • • • • • • • • • • • • • 58

APPENDIX A-Tables 1 through 34 . . . . . . . . A-1

APPENDIX B-Figures B.1 through B.52 • • . • . . B-1

DISTRIBUTION . . . . . . . . . . . . Distr-1 


\section{LIST OF FIGURES}

1. Typical Gas Phase Curve from ADF Mode1 14

2. Aerosol Development Facility Layout 23

3. Photograph of SAT Vessel Being Sampled with Maypack Sampler.

4. ADF Maypack (Schematic) 27

5. Maypack Samples Prepared for Gamma Energy Analysis 28

6. Comparison of Elemental Iodine Gas Phase Concentration-Continuous Versus Instaneous Release

7. Effect of Agitation on Elemental Iodine Gas Phase Concentration

B.1. Iodine Gas Phase Concentration, Run SA 21 B.1

B.2. Iodine Gas Phase Concentration, Run SA 23 B.2

B.3. Iodine Gas Phase Concentration, Run IA $26 \quad$ B.3

B.4. Iodine Gas Phase Concentration, Run SA 28 B.4

B.5. Iodine Gas Phase Concentration, Run IA 32 B.5

B.6. Iodine Gas Phase Concentration, Run IA 33 B.6

B.7. Iodine Gas Phase Concentration, Run IA $39 \quad$ B.7

B.8. Iodine Gas Phase Concentration, Run IA 40 B. 8

B.9. Iodine Gas Phase Concentration, Run IB 41 B.9

B.10. Iodine Gas Phase Concentration, Run IB 42 B. 10

B.11. Iodine Gas Phase Concentration, Run SA $43 \quad$ B.11

B.12. Iodine Gas Phase Concentration, Run SA $44 \quad$ B. 12

B.13. Iodine Gas Phase Concentration, Run SB 48 B.13

B.14. Iodine Gas Phase Concentration, Run SB $50 \quad$ B.14

B.15. Iodine Gas Phase Concentration, Run SB 53 B.15

B.16. Iodine Gas Phase Concentration, Run SB $60 \quad$ B.16 


\section{LIST OF FIGURES (contd)}

B.17. Iodine Gas Phase Concentration, Run SB $61 \quad$ B.17

B.18. Iodine Gas Phase Concentration, Run SB 63 B.18

B.19. Iodine Gas Phase Concentration, Run SB 64 B.19

B.20. Iodine Gas Phase Concentration, Run SB $74 \quad$ B.20

B.21. Iodine Gas Phase Concentration, Run SB $78 \quad$ B.21

B.22. Gas Phase Concentrations, Run IA 32 B.22

B.23. Gas Phase Concentrations, Run IA $33 \quad$ B.23

B.24. Gas Phase Concentrations, Run IA $39 \quad$ B.24

B.25. Gas Phase Concentrations, Run IA $40 \quad$ B.25

B.26. Gas Phase Concentrations, Run IB 41 B.26

B.27. Gas Phase Concentrations During the Release Period,

B.28. Gas Phase Concentrations, Run IB 42 B.28

B.29. Gas Phase Concentrations, Simulant Cesium B.29

B.30. Gas Phase Concentrations, Simulant Tellurium B.30

B.31. Gas Phase Concentrations, Simulant Ruthenium B.31

B.32. Gas Phase Concentrations, Simulant Barium B.32

B.33. Gas Phase Concentrations, Simulant Uranium B.33

B.34. Mass Transfer Coefficient Versus Steam Flux,
Total Iodine

B.35. Mass Transfer Coefficient Versus Steam Flux,
Particulate Iodine B.35

B.36. Mass Transfer Coefficient Versus Steam Flux,
Elemental Iodine B.36

B.37. Mass Transfer Coefficient Versus Steam Flux, Cesium B.37 


\section{LIST OF FIGURES (contd)}

B.38. Mass Transfer Coefficient Versus Steam Flux, Tellurium

B.39. Mass Transfer Coefficient Versus Steam Flux, Ruthenium

B.40. Mass Transfer Coefficient Versus Steam Flux, Barium

B.41. Mass Transfer Coefficient Versus Steam Flux, Uranium

B.42. Iodine Distribution Versus Series IA

B.43. Iodine Distribution Versus Series SA

B.44. Iodine Distribution Versus Series IB

B. 43

B.45. Iodine Distribution Versus Series SB

B.46. Cesium Distribution Versus Series IB

B.47. Cesium Distribution Versus Series SB

B.48. Tellurium Distribution Versus Series IA

B. 45

B.49. Tellurium Distribution Versus Series SB

B. 45

B.50. Ruthenium Distribution, Series $S B$

B. 46

B.51. Barium Distribution, Series SB

B. 46

B.52. Uranium Distribution, Series IA 


\section{LIST OF TABLES}

1 Series I Experimental Conditions A.1

2 Series $S$ Experimental Conditions A.2

3 Fission Product Release from Irradiated Specimens A.4

4 Iodine Form as Sampled from Delivery Line A.5

5 Effect of Iodine Mass Loading on Maypack

Distribution

A. 6

6 Iodine Form in Containment Gas Phase After 10 min Containment Time

A. 7

7 Iodine Form in Containment Gas Phase After $5 \mathrm{hr}$ Containment Time

A. 8

8 Effect of Mass Released on Iodine Form A.9

9 Gas Phase Mass Transfer Coefficients--Total Iodine A.10

10 Gas Phase Mass Transfer Coefficients--Particulate Iodine

A. 11

11 Gas Phase Mass Transfer Coefficients--Elemental Iodine

A. 12

12 Gas Phase Mass Transport Coefficients--Cesium A.13

13 Gas Phase Mass Transport Coefficients--Tellurium A.14

14 Gas Phase Mass Transport Coefficients--Ruthenium A.15

15 Mass Transfer Coefficients--Barium A.16

16 Gas Phase Mass Transfer Coefficients--Uranium A.17

17 Summary of Gas Phase Mass Transfer Coefficients A.18

18 Comparison of $\mathrm{K}_{\mathrm{G}}$ for Various Aerosol Components A.19

Gas-Liquid Partition Coefficients for Elemental
Iodine

20 Iodine Distribution in Containment Vessel After $5 \mathrm{Hr}$ A.21 


\section{LIST OF TABLES (contd)}

21 Cesium Distribution in Containment Vessel After $5 \mathrm{Hr}$ A.22

22 Tellurium Distribution in Containment Vessel After $5 \mathrm{Hr}$

23 Ruthenium Distribution in Containment Vessel After $5 \mathrm{Hr}$

24 Barium Distribution in Containment Vessel After $5 \mathrm{Hr}$ A.24

25 Uranium Distribution in Containment Vessel After $5 \mathrm{Hr}$

26 Summary of Distribution After $5 \mathrm{hr}$ Containment Aging A.25

27 Solubility in Steam Condensate After 10 min Containment Time

28 Solubility in Steam Condensate After 5 hr Containment Time

29 Iodine Form in Condensate as Measured by Extraction

30 Overall Material Recovery

31 Effect of Aerosol Complexity on Iodine Containment Behavior

32 Effect of Cladding Type on Iodine Behavior

33 Comparison of Iodine Behavior in Containment Vessels with Fresh Versus Aged Painted Walls 



\section{COMPARISONS OF THE CONTAINMENT BEHAVIOR OF \\ A SIMULANT WITH FISSION PRODUCTS \\ RELEASED FROM IRRADIATED UO 2 \\ R. K. Hilliard \\ L. F. Coleman \\ J. D. McCormack \\ I. INTRODUCTION}

A major objective of the Containment Systems Experiment (CSE) is to demonstrate the transport behavior of fission products during conditions representative of major accidents to water cooled and moderated nuclear reactors. (1) Al1 reactors have some provision for containing fission products that might escape from the primary reactor vessel during an accident, and the CSE structure includes several different types of safeguard features used in large modern power reactors. (1) Tests will be performed in a manner whereby mass transport models derived from theory and small-scale tests can be confirmed in an engineering-scale facility. The proven mathematical models will then provide reliable means for estimating fission product transport under a wide variety of potential accident conditions in a reactor system.

The experimental program ${ }^{(1)}$ calls for repetitive releases of large masses of fission product aerosols: a requirement well met by the use of simulants but impractical if highly irradiated fuels are used. (2) The use of simulants is justified only if the simulants' behavior within the containment environment is identical to, or can be correlated with, that of "real" fission products: that is, fission products released from irradiated power reactor fuel elements. 
The Aerosol Development Facility (ADF) is a small-scale containment laboratory operated in support of the CSE at the Pacific Northwest Laboratory (PNL). One of its functions is to compare the behavior of the CSE fission product aerosol with that of fission products released from overheated $\mathrm{UO}_{2}$. The findings are the substance of this report. A related study is in progress at the Oak Ridge National Laboratory (ORNL) where the containment behavior of the CSE simulant is being compared with the aerosol released from highly irradiated fuels. in the Containment Mockup Facility (CMF) and in the Containment Research Installation (CRI).

This report is one of a series of topical reports on the CSE program. The first ${ }^{(1)}$ was a general description of the experimental program and the planned experimental facility. other reports have dealt with a mathematical model and computer code for pressure and temperature transients in containment systems, (3) and the method of analyzing samples generated in the CSE and ADF for the amounts of each of several fission product radionuclides. (4) 


\section{SUMMARY AND CONCLUSIONS}

Experiments have been performed in a manner whereby a direct comparison could be made between the transport of simulant and reference fission product aerosols in a condensing steam containment atmosphere. The reference fission product aerosol was produced by heating stainless steel clad $\mathrm{UO}_{2}$ irradiated to $1 \times 10^{17} \mathrm{nvt}(\sim 0.35 \mathrm{MWd} / \mathrm{T})$ in oxidizing and reducing atmospheres at various temperatures up to that of molten $\mathrm{UO}_{2}$. The simulant aerosol was produced by volatilizing stable fission product elements or compounds that were radioactively traced for analytical purposes. The aerosol was injected into a containment vessel filled with an equimolar steam and air mixture. Steam condensed at a steady rate by heat transfer through the vessel surfaces and was replaced by a continuous steam addition to maintain isothermal and isobaric containment conditions.

In order to provide a valid basis for comparing the transport of simulant and reference aerosols, a theoretical mode 1 was developed. The model assumes that the bulk gas in containment is well mixed by eddy diffusion and that mass transfer from the gas to the vessel surface is limited by diffusion across a boundary layer. The surface of the vessel is wet by condensing steam. Transport from the gas to the liquid film is limited by the gas phase mass transfer coefficient until equilibrium between gas and liquid is attained. After equilibrium is obtained, transport is limited by the dilution rate of the liquid film by fresh condensate.

The gas phase mass transfer coefficient is a function of the sum of two quantities: the bulk fluid flux to the wall caused by condensation of steam, and diffusion across the boundary layer. In the current tests, the boundary layer was laminar, but in larger vessels it could be turbulent. 
Watson recognized that the diffusive contribution to mass transport was neglected, but he assumed that the bulk flow term greatly predominated so that his simplified model gave satisfactory, though conservatively low, results.

The authors, in cooperation with J. G. Knudsen, " made a mathematical analysis of the transport of fission products in a condensing steam-air mixture. Though adaptable for other systems, the simplified case to fit the ADF tests will be discussed here. The assumptions were:

1) Fission products were instantaneously injected into a steamair atmosphere and were we 11 mixed at all times.

2) All surfaces were wet by steam condensation that formed a continuous film draining to the sump.

3) Fission products were transferred across a gas boundary laye $r$ at the liquid surface by a combination of bulk and diffusive flow.

4) Fission products we re absorbed reversibly by the liquid film, with equilibrium controlled by a suitable gas-liquid partition coefficient.

5) After absorption in the liquid, the fission products reacted irreversibly with the vessel walls with a firstorder rate constant.

6) The concentration in the liquid film was assumed constant throughout, but differed from that in the sump by some proportionality constant. The mode 1 is adaptable to unsteady pressure and steam flux conditions, but the discussion will be limited to the ADF experimental condition of thermal equilibrium with steam-feed to make up for losses by condensation.

* Consultant to PNL. Assistant Dean of Engineering, Oregon State University, Corvaliz, oregon. 
If we concern ourselves only with changes in the gas phase, the material balance for any single species of fission product or simulant is:

$$
\begin{aligned}
& \text { Input }=\text { Output }+ \text { Accumulation } \\
& 0=K_{D} A\left(C_{G}-C_{G}\right)+A N_{B} X_{i}+\frac{\mathrm{dC}_{G}}{d t},
\end{aligned}
$$

where $K_{D}=$ mass transfer coefficient for diffusion through boundary 1 aye $\mathrm{r}, \mathrm{cm} / \mathrm{sec}$

$$
\begin{aligned}
A= & \text { vessel surface area, } \mathrm{cm}^{2} \\
C_{G}= & \text { gas phase concentration, mole } / \mathrm{cm}^{3} \\
C_{G}^{\prime}= & \text { gas phase concentration in equilibrium with } \\
& 1 \text { iquid, mole } / \mathrm{cm}^{3} \\
N_{B}= & \text { flux of bulk gas to walls, mole } \mathrm{sec}^{-1} \mathrm{~cm}^{-2} \\
X_{i}= & \text { mole fraction of species "i" in gas, } \\
& \text { mole i/mole total } \\
V= & \text { vessel volume, } \mathrm{cm}^{3} \\
t= & \text { time, sec }
\end{aligned}
$$

The first term on the right side is the rate of transfer from the gas to the liquid by diffusion across the concentration gradient. The second term is the transfer contributed by bulk gas flux to condensing surfaces. The third term is the difference between input and output. Since instantaneous release was assumed, the left term is zero at $t>0$.

The mole fraction, $X_{i}$, can be expressed as

$$
x_{i}=\frac{{ }_{G}{ }^{R T}}{P} \text {, }
$$

where $R$ = universal gas constant

$\mathrm{T}=$ absolute temperature in bulk gas

$\mathrm{P}=$ total pressure 
Note that $P$ is total pressure in the vessel, not just saturated steam pressure. The bulk flow term then becomes:

$$
\mathrm{AN}_{\mathrm{B}} \mathrm{X}_{\mathrm{i}}=\mathrm{AN}_{\mathrm{B}} \frac{\mathrm{C}_{\mathrm{G}} \mathrm{RT}}{\mathrm{P}}
$$

and Equation (4) can be rewritten

$$
0=K D_{A}\left(C_{G}-C_{G}^{-}\right)+\left(\frac{N_{B}{ }^{R T}}{P}\right) A C_{G}+V_{d t}{ }_{d C} .
$$

Now, the equilibrium back pressure, $C_{G}$, is a function of the liquid surface concentration. The relationship is conveniently put in the form of a dimensionless gas-liquid partition coefficient, $\mathrm{H}$

$$
\mathrm{C}_{\mathrm{G}}=\mathrm{HC}_{\mathrm{L}}
$$

At short containment times, $C_{L}$ is very small and $C_{G}>C_{G}^{-}$. For this condition, Equation (7) becomes

$$
0 \approx K_{D} A_{G}+\left(\frac{N_{B} R T}{P}\right) A C_{G}+V_{\frac{d C}{G}}
$$

Rearranging,

$$
\frac{\mathrm{dC}_{G}}{\mathrm{dt}}=-\left(\mathrm{K}_{\mathrm{D}}+\frac{\mathrm{N}_{\mathrm{B}}{ }^{\mathrm{RT}}}{\mathrm{P}}\right) \frac{\mathrm{A}}{\bar{V}} \mathrm{C}_{G} .
$$

A new transfer coefficient is now defined in Equation (11):

$$
K_{G}=K_{D}+\frac{N_{B} R T}{P}
$$


where $\mathrm{K}_{\mathrm{G}}=$ overall gas phase mass transfer coefficient in $\mathrm{cm} / \mathrm{sec}$. Substituting in Equation (10) gives

$$
\frac{d C_{G}}{d t}=-K_{G} \frac{A}{\bar{V}} \quad C_{G} \cdot
$$

Separation of variables and integration gives, with the initial condition that $\mathrm{C}_{\mathrm{G}}=\mathrm{C}_{\mathrm{O}}$ at time zero:

$$
\frac{\mathrm{C}_{G}}{\mathrm{C}_{\mathrm{O}}}=\exp \quad\left(-\mathrm{K}_{\mathrm{G}} \frac{\mathrm{A}}{\mathrm{V}} \mathrm{t}\right)
$$

Equation (13) applies only as long as the bulk gas concentration, $\mathrm{C}_{\mathrm{G}}$, greatly exceeds the equilibrium concentration, $\mathrm{C}_{\mathrm{G}}^{-}$. At equilibrium, $C_{G}=C_{G}^{-}$and the diffusive term in Equation (7) goes to zero. Furthermore, though the bulk flow mechanism continues to operate, $\mathrm{C}_{\mathrm{G}}$ is forbidden to decrease lower than the equilibrium concentration because of reversibility. Therefore, the gas concentration decreases at a rate fixed by the dilution of the liquid film by fresh condensing steam.

Turning our attention to the liquid phase, we find the material balance is

$$
\begin{aligned}
& \text { Input = Output }+ \text { Accumulation } \\
& { }_{K_{G}} A^{A}\left({ }_{G}-C_{G}^{-}\right)=B_{L} S+R_{L} A_{L}+L \frac{d_{L}}{d t},
\end{aligned}
$$

where

$$
\begin{aligned}
C_{L}= & 1 \text { iquid film concentration, mole } / \mathrm{cm}^{3} \\
S^{3}= & \text { steam condensation rate, } \mathrm{cm}^{3} \text { liquid/sec } \\
R_{L}= & 1 \text { iquid-solid reaction rate constant, cm/sec } \\
B^{\prime}= & C_{L}^{-} / C_{L}=\text { factor relating film and sump } \\
& \text { concentration } \\
C_{L}= & 1 \text { iquid concentration in vesse } 1 \mathrm{sump}, \mathrm{mole} / \mathrm{cm}^{3} \\
L^{\prime}= & \text { volume of liquid film holdup, } \mathrm{cm}^{3}
\end{aligned}
$$


The left term is the input to the liquid phase by transfer from the gas. The first term on the right is removal from the film by flow to a sump. The second term on the right is transferred to solid surfaces by irreversible reaction with the walls. The last term is the difference between input and output. At equilibrium,

$$
\mathrm{C}_{\mathrm{G}}^{\prime}=\mathrm{HC}_{\mathrm{L}_{\mathrm{eq}}} \text {, }
$$

and

$$
v_{\frac{d C}{d t}}^{-}=B S C_{L_{e q}}+R_{L} A C_{L_{e q}}+L \frac{d C_{L_{e q}}}{d t},
$$

$V H \frac{\mathrm{dC}_{L_{e q}}}{d t}=C_{L_{e q}}\left(B S+R_{L} A\right)+L \frac{d_{L_{e q}}}{d t}$,

$$
\frac{d C_{L}}{d t}=\left(\frac{B S+R_{L} A}{V H-L}\right) C_{L_{e q}} .
$$

Integrating and using the initial condition that

$$
\begin{aligned}
& \text { at } t=0, C_{L_{e q}}=\frac{\left(C_{G}\right)_{0}}{H}, \\
& \frac{H}{\left(C_{G}\right)_{0}} C_{L_{e q}}=\exp \left[\frac{B S+R_{L}^{A}}{V H-\frac{L}{L}}\right] t .
\end{aligned}
$$

Substitution of Equation (15) gives, for equilibrium,

$$
\frac{C_{G}}{\left(C_{G}\right)_{0}}=\exp \left[-\left(\frac{B S+R_{L}^{A}}{L-V H}\right) t\right] .
$$


For systems with small gas-liquid partition coefficients (e.g., $\mathrm{I}_{2}$, HI, particles) and where $\mathrm{R}_{\mathrm{L}}$ is low, Equation (20) simplifies to

$$
\frac{{ }^{C_{G}^{\prime}}}{\left(C_{G}^{\prime}\right)_{O}}=\exp -\frac{B S}{L} t \text {, }
$$

which states that at equilibrium, the transfer from gas to liquid is controlled by the dilution rate of the liquid film by fresh condensate: the ratio BS/L. The assumption that concentration within the liquid film is uniform may be a poor one at high transfer rates, and liquid diffusion should be considered.

However, on the basis of the described model, a computer program was written that gives the roots of the equations and tabulated values of $\mathrm{C}_{\mathrm{G}} / \mathrm{C}_{\mathrm{O}}$ versus time. Expressions for time dependence of concentration in the 1iquid film and material transferred to solid surfaces were also obtained. Briefly, they predict an initial rapid buildup in liquid concentration followed by a slow decline asymptotically approaching zero. The total mass holdup by both liquid film and solid surfaces rises at a rapid initial, nearly linear rate, reaches a maximum, then decreases with time to an asymptotic value that is the total mass reacted with solid surfaces.

Figure 1 shows a typical gas phase curve from this program obtained by selecting various combinations of model input parameters to obtain the best fit to the experimental results for elemental iodine in ADF Run 63. Without elaborating on experimental results at this point, we should discuss several 


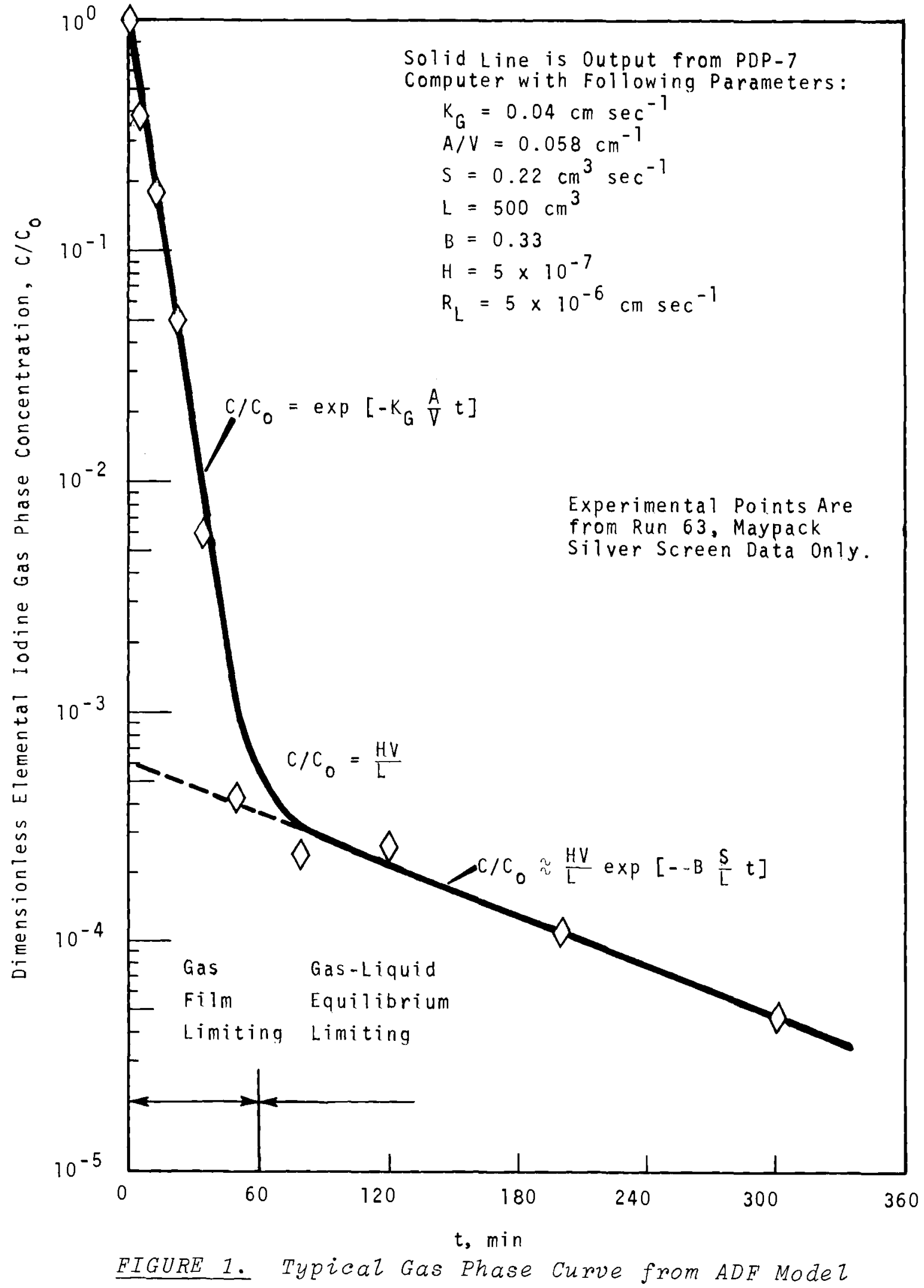


important features of the figure. First, the curve of concentration versus time has two segments. At early times the slope is approximately equal to $-K_{G} A / V$, agreeing with Equation (13). For a given vessel geometry (A/V), the transport depends only on the value of the gas phase mass transfer coefficient, $\mathrm{K}_{\mathrm{G}}$. All other variables are unimportant except as they affect the mass transfer coefficient.

The first segment of the curve holds until gas-liquid equilibrium is approached. A second exponential segment is seen as predicted by Equation (20) and approximated by Equation (21). Extrapolation of the equilibrium curve gives an intercept at time zero of $\mathrm{HV} / \mathrm{L}$. At zero condensation rate (i.e., $S=0$ ), the equilibrium curve would be constant at $\mathrm{C} / \mathrm{C}_{\mathrm{O}}=\mathrm{HV} / \mathrm{L}$.

Morrison et al. $(11,12)$ derived transport models for both dry and wet systems. Their wet model (COVEDEP) is very similar to the ADF model discussed above. They included terms for source input and for leakage and engineered safeguards (filters and sprays) removal and combined several forms of iodine in the same equations. For the ADF test conditions, where these three terms were zero, their model reduces essentially to the authors' and yields results similar to Figure 1.

British workers $(13,14)$ have released iodine and particles into large air-filled containment vessels and correlated their results by use of an empirical "deposition velocity":

$$
v_{D}=\frac{N_{i} M}{C_{i}} \text {, }
$$

where $v_{D}=$ deposition velocity constant, $\mathrm{cm} / \mathrm{sec}$

$\mathrm{M}=$ molecular weight of transported material, $\mathrm{g} / \mathrm{mole}$

$C_{i}=$ gas concentration near surface, $\mathrm{g} / \mathrm{cm}^{3}$ 
The value of $\mathrm{K}_{\mathrm{G}}$ can now be calculated by knowledge of the terms in Equation (11). $\mathrm{N}_{B}, \mathrm{~T}$, and $\mathrm{P}$ are experimental measurements. $R$ is the universal gas constant. Values for $K_{D}$ can be predicted by use of the Colburn equation for heat and mass transfer analogy. (7) Sherwood and Pigford (Reference 7, p. 61) show the Colburn equation as:

$$
j_{D}=\frac{K_{D} P_{B M}}{U_{a v}{ }^{P}}(S c)^{2 / 3},
$$

where $j_{D}=$ dimensionless Colburn factor

$$
\begin{aligned}
\mathrm{P}_{\mathrm{BM}}= & \text { log mean of pressure of inert gas at phase } \\
& \text { boundary and in bulk of fluid, atm } \\
\mathrm{U}_{\mathrm{av}}= & \text { gas velocity in bulk fluid, } \mathrm{cm} / \mathrm{sec} \\
\mathrm{P}= & \text { total pressure, atm } \\
\mathrm{SC}= & \text { Schmidt number }=\mu / \rho \mathrm{D} \\
\mu \quad= & \text { fluid film viscosity, } \mathrm{g} / \mathrm{sec} \mathrm{cm} \\
\rho \quad= & \text { fluid film density, } \mathrm{g} / \mathrm{cm}^{3} \\
\mathrm{D}= & \text { diffusion coefficient, } \mathrm{cm}^{2} / \mathrm{sec}
\end{aligned}
$$

For conditions of interest in containment studies, $\mathrm{P}_{B M}$ is essentially equal to $P$. The Schmidt number can be calculated with good accuracy for gaseous materials. For aerosols, the diffusion coefficient can be estimated by use of the Einstein particle diffusion equation. (16) For transfer to flat plates, which is approximated in containment vessels, the bulk gas velocity, $U_{a v}$, is the maximum velocity near the walls, as pointed out by Watson. (10) Perry (8) gives two expressions for the Colburn $j_{D}$ factor: one for the laminar boundary layer region and another for the turbulent region. For the laminar region,

$$
j_{D}=0.664 \operatorname{Re}_{x}^{-0.5} \text {, }
$$

where $\operatorname{Re}_{x}$ is the length Reynolds number,

$$
\operatorname{Re}_{\mathrm{X}}=\frac{\ell \mathrm{U} \rho}{\mu} \text {, }
$$

where $\ell=1$ ength, $\mathrm{cm}$. 
For the turbulent region, which might exist in larger vesse1s,

$$
j_{D}=0.036 \operatorname{Re}_{x}^{-0.2}
$$

Some insight can be gained as to which equation applies for a particular system by assuming that transition from laminar to turbulent regions occurs at $\operatorname{Re}_{x} \approx 10^{5}$ as suggested by Bird et al. (5). For the ADF test conditions, the 1 aminar region probably prevailed throughout the vessel.

From the foregoing, it is seen that for any given containment vesse 1 and containment atmosphere specified, al1 factors required to calculate $\mathrm{K}_{\mathrm{D}}$ are known except the bulk gas velocity. Unfortunately, attempts to measure the gas velocity in the ADF were unsuccessful because velocities were generally below the sensitivity limit ( $30 \mathrm{ft} / \mathrm{min}$ ) of the heated thermopile anemometers used. To fit the experimental results, velocities in the range of 0.1 to $10 \mathrm{ft} / \mathrm{min}$ would have to be used in the Colburn equation.

Because of the absence of direct gas velocity measurements, the assumption was made that the velocity was proportional to the makeup steam feed rate, so that

$$
K_{D}=k(S / A)^{0.5} \text {. }
$$

The proportionality constant, $k$, was determined by empirical fit of the average experimental values at low steam feed rates. A second assumption was made that some of the steam feed condensed near the inlet wall nozzle before mixing with the fission products, and the term $N_{B} R T / P$ was adjusted accordingly. After insertion of the appropriate ADF test condition values, Equation (11) becomes

$$
K_{G}=400 \frac{S}{A}+6.0\left(\frac{S}{A}\right)^{0.5}
$$


Equation (33) is used in later sections as a basis for discussion of the ADF test results. It applies only to the ADF test conditions of temperature, pressure, and geometry. The validity of this equation and the more general expression of Equation (II) should be checked in experiments where gas velocity profiles can be measured. 


\section{EXPERIMENTAL CONDITIONS}

The ADF is located in the same building with CSE and is operated by the CSE staff. Much of the aerosol generation and injection equipment is the same as used in the large-scale CSE tests. One of the purposes of the ADF was to provide comparative experiments for confirming the adequacy of simulant aerosols. (17) Results of ADF experiments are especially pertinent to those expected in the CSE because of the similarity of aerosol generation. Over fifty tests have been performed, seven of which were with trace-irradiated $\mathrm{UO}_{2}$ sources. Not all of the remainder $c$ an be used in comparing results because some were made for other purposes, and conditions varied significantly from those used in the irradiated source tests. However, about 20 experiments with simulants permit a reliable comparison to be made.

\section{EXPERIMENT STRUCTURE}

The use of simulants for transport experiments is justified technically if either:

1) the physical and chemical properties of real and simulant materials are identical or if the effects of differences can be correlated; or

2) environmental conditions are transport rate controlling to the extent that differences in material properties do not affect transport significantly.

Information on material characteristics, both for simulants and "real" fission products, is being gathered at PNL and at ORNL. Since our knowledge of the physical and chemical characteristics of fission products apt to be released into containment vessels was incomplete, we chose the second approach for the present study. Tests were made using aerosols of fission products released from heated irradiated $\mathrm{UO}_{2}$ (Series I). A second series (Series S) 
used simulant aerosols. Environmental conditions within the experimental containment vessel were kept as constant as possible in both series so that any differences in transport observed would be attributable to differences in aerosol properties. This objective was only partially successful in that it was found that only slight differences in environmental conditions (notably steam condensation rate) caused significant differences in transport rate. Therefore, Series I tests should not be compared directly with series $S$, but allowance must be made for variations in individual test conditions. This is possible by using the mathematical models developed in the previous section.

Steady-state atmospheric conditions were selected for all the tests reported here. This was done so that important transport measurements could be made accurately and reproduced from test to test. Model confirmation was also easily accomplished.

In order to provide more than one environmental condition for comparison, two test subseries were conducted: Subseries A with high heat transfer through the containment walls and consequent large steam condensation flux and convection currents, and Subseries $B$ with relatively low heat transfer, steam flux, and convection.

\section{EXPERIMENTAL EQUIPMENT}

A sketch of the major experimental equipment is shown in Figure 2. Materials volatilized by inductive or resistance heating at the aerosol generation station were injected into either of two containment vessels. The PAT vessel (painted aerosol tank) was $1.54 \mathrm{~m}^{3}$ contained volume, $8.0 \mathrm{~m}^{2}$ internal surface area, carbon steel painted with Phenoline 300 ,* a

* Carboline Co., St. Louis, Missouri 


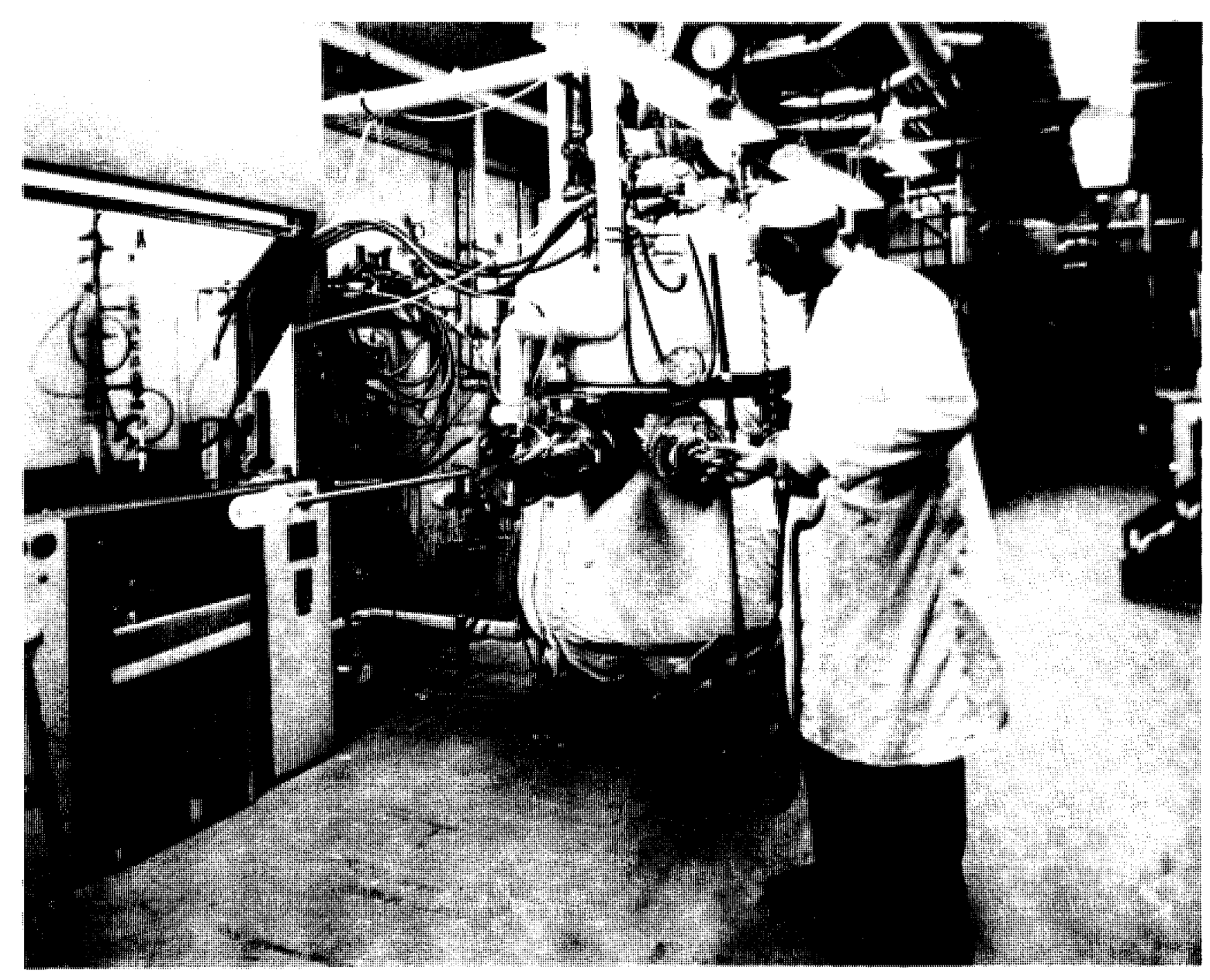


bagged separately. Lastly, the granular charcoal was poured into an 8 oz plastic jar with screw lid and shaken before analysis. Thus, each Maypack sample yielded four subsamples for analysis. Supplementary samples were taken occasionally of individual silver screens, nose cone decontaminating agents, and backup traps. Figure 4 is a schematic drawing of the Maypack. Figure 5 shows the packaged samples ready for gamma analysis.

The steam condensate was drawn periodically from the vessel sump directly into $500 \mathrm{ml}$ polyethylene bottles. The sump was drawn dry at each sampling. Condensate samples were filtered, and the filters washed with $100 \mathrm{ml}$ of distilled water. The filtrate and the filter were analyzed separately.

After injection was completed, the generation apparatus and aerosol delivery 1 ine to the vessel were decontaminated, and the reagent solutions were analyzed.

\section{TEST CONDITIONS}

Irradiated Source Tests

The conditions used for the seven tests with irradiated sources are listed in Table 1 (all tables are given in Appendix A). The sources were sintered natural $\mathrm{UO}_{2}$ peliets, $95.5 \%$ theoretical density, clad in 304L SS, measuring 0.500 in. $\mathrm{OD}$ by $3 \mathrm{in}$. long. The weight of the $\mathrm{UO}_{2}$ was $68.2 \mathrm{~g}$; the weight of stainless steel was $24.5 \mathrm{~g}$. They were irradiated to about $1 \times 10^{17} \mathrm{nvt}(0.35 \mathrm{MWd} / \mathrm{T})$ and allowed to cool from 3 to 5 weeks before using. In each test one of the sources was heated to destruction in a different manner, as listed in Table 1 . Temperatures were either the melting point of $\mathrm{UO}_{2}$ or slightly above the clad melting temperature. Time at temperature was either 6 or $60 \mathrm{~min}$. Heatup time from clad melting to $\mathrm{UO}_{2}$ melting was on the order of seconds. Cooldown was rapid because of the cooling jacket on the quartz furnace; the temperature dropped 


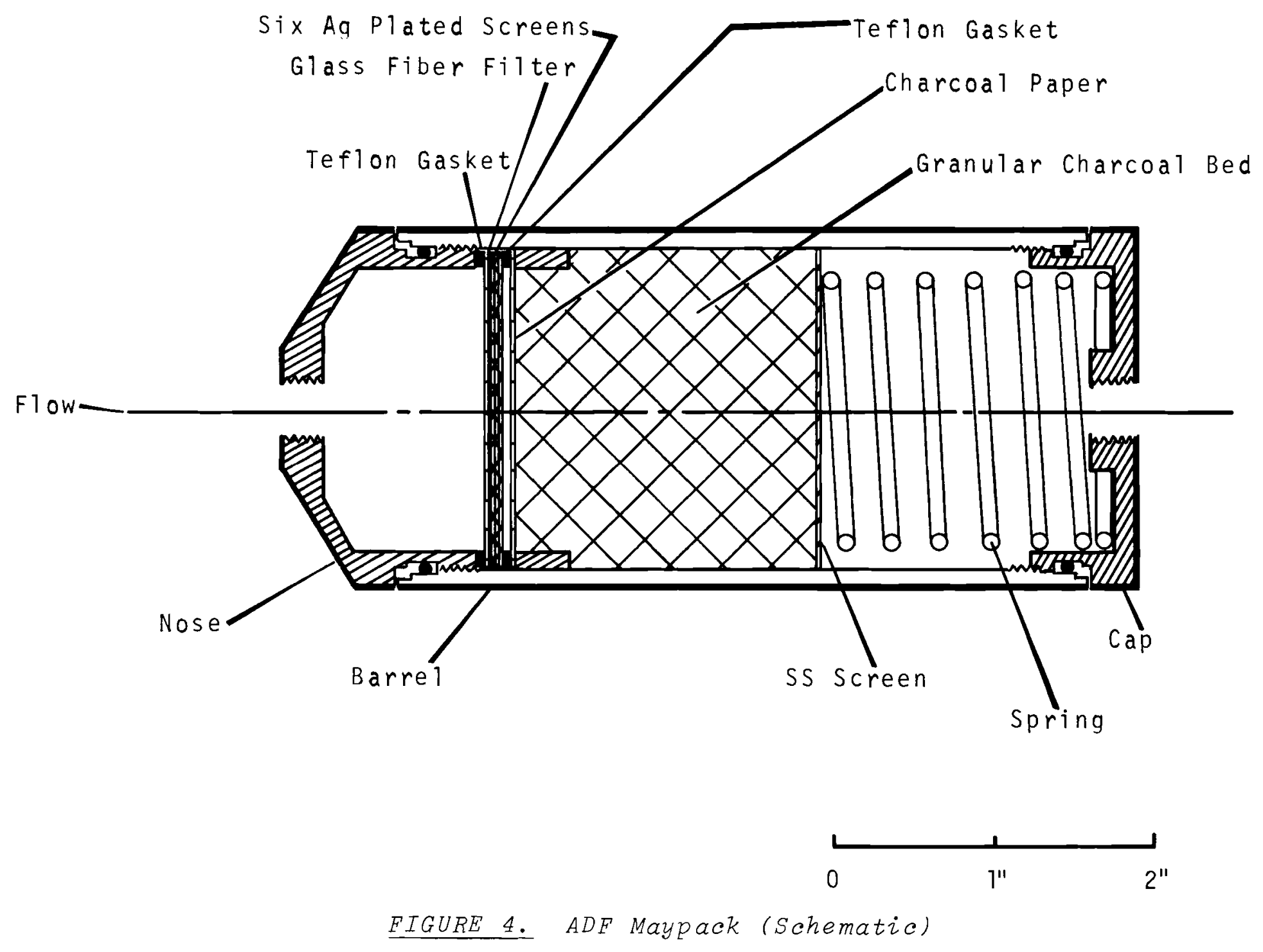




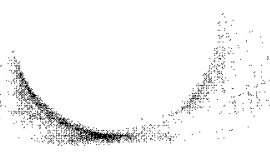

A

B
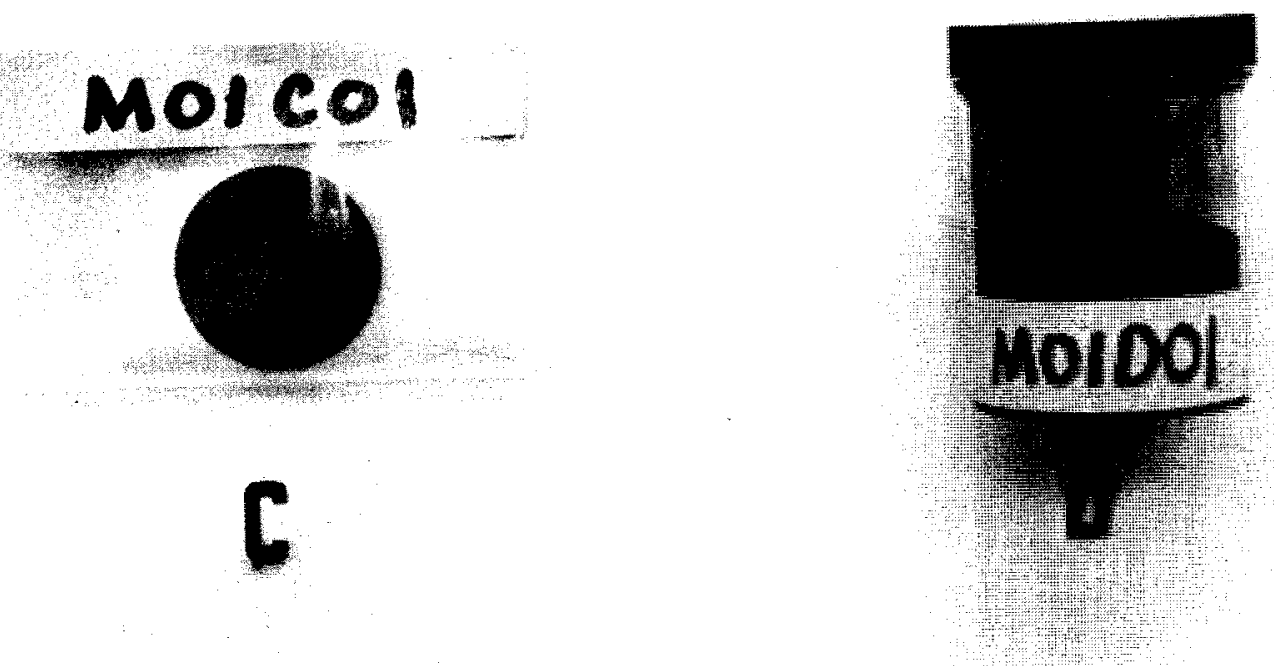

Neg $45959-16$

FIGURE 5. Maypack Samples Prepared for Gamma Energy Analysis 
to less than $1000{ }^{\circ} \mathrm{C}$ in $1.5 \mathrm{~min}$. The furnace sweep gas was changed from test to test from oxidizing (air or steam-air mixtures) to reducing (pure steam or steam-hydrogen mixture). The sweep gas flow rate was constant at 28 liters (STP) per min. At the end of the heating period the furnace power was shut off, flow through the furnace continued for several minutes, then the valve on the containment vessel was closed. Gas samples were taken from the delivery line near the tank inlet during all injections. "Containment time" is defined as the time after aerosol injection started.

The containment conditions within each test series were almost the same. Prior to release, the vessel was heated to temperature with steam (the vessel had no auxiliary heaters) and permitted to reach thermal equilibrium as shown by constant temperature, pressure, and condensation rate. Steam feed was continued after injection to maintain thermal equilibrium. Usually after about one hour containment time, the steam feed rate required adjustment in order to keep isothermal conditions, and the condensation rate changed accordingly.

The two rates are listed in Table 1. A slight vacuum was maintained in the vessel to prevent loss of aerosol by leakage.

The PAT tank was used in all the irradiated source runs, and no mechanical agitation was used. The paint in the PAT had been exposed to $46 \mathrm{hr}$ of steaming at 80 to $100{ }^{\circ} \mathrm{C}$ prior to the first irradiated source test and had accumulated $300 \mathrm{hr}$ of steam exposure at the end of the seventh test. Some blistering of the paint was noted at that time.

$\underline{\text { Simulant Tests }}$

The simulant test conditions are listed in Table 2. Conditions varied more than in the irradiated source tests, chiefly because test objectives other than simulant verification were being pursued. Both the PAT and the SAT vessels 
Figure 6 illustrates the great difference in gas phase concentration within containment for the two cases. In Run SB 63 the release was essentially instantaneous, while in Run $S B 74$ the release rate was constant for $1 \mathrm{hr}$. Containment conditions were nearly identical, implying that the removal rate constants $\left(K_{G} \frac{A}{V}\right)$ were the same. That this was so is shown by the fact that the concentration half lives were the same after release was terminated. For the sake of comparison, the mass released in Run 74 has been normalized to that in Run 63. After 1 hr, the concentration was 200 times greater for the continuous release case than when the same mass was injected instantaneously. After release was terminated in Run 74 , the behavior was very similar to the early portion of Run 63 .

This discussion is intended to alert the reader to expected differences in containment behavior if the release term differs. It should be pointed out that although the case of a constant release rate was demonstrated, similar effects would result with nonconstant (but continuous) release rates.

\section{Irradiated Source Tests}

Table 3 lists the percentage of fission products released and the estimated mass injected to containment for the irradiated source tests. The mass released varied from a few hundredths micrograms to a few micrograms of each fission product type. About $80 \%$ of the iodine was released in 6 min, $99 \%$ in $1 \mathrm{hr}$ when the $\mathrm{UO}_{2}$ was melted. Only $75 \%$ was released in $1 \mathrm{hr}$ when the temperature was held to slightly above the stainless steel clad melting point. In the latter test (Run 40), the iodine gas phase concentration was held at higher values by this continued, but unknown, release rate. Furnace atmosphere, oxidizing or reducing, did not affect the iodine release fraction. 
33

BNWL - 581

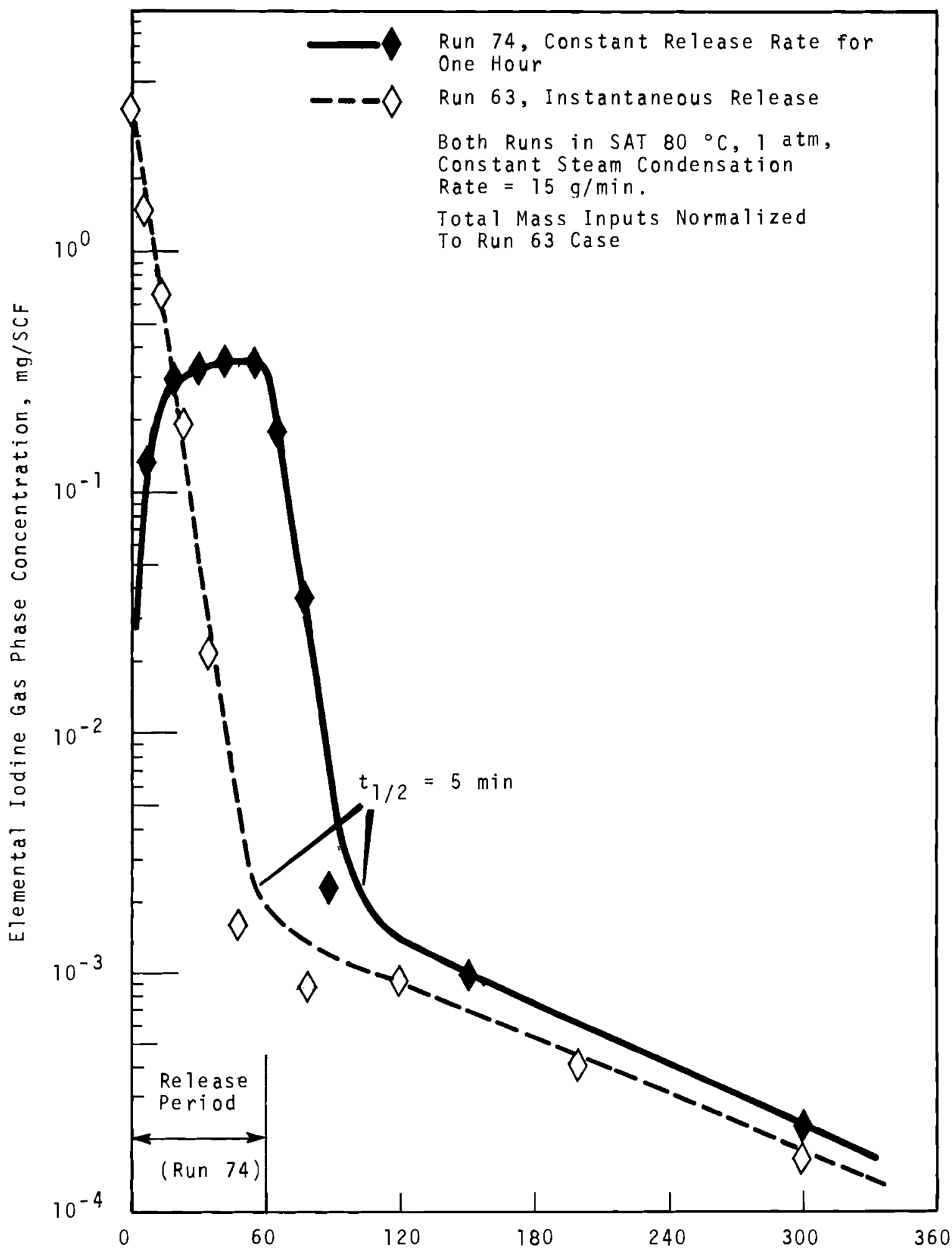

Time after Injection Started, min

FIGURE 6. Comparison of Elemental Iodine Gas Phase Concentration--Continuous Versus Instantaneous Re lease 
About $65 \%$ of the cesium was released in $6 \mathrm{~min}, 95 \%$ in $1 \mathrm{hr}$ when the $\mathrm{UO}_{2}$ was melted. At clad melting temperature, on $1 \mathrm{y} 30 \%$ was released in $1 \mathrm{hr}$. No dependence on furnace atmosphere was noted.

Tellurium was also quite volatile in all runs. About $50 \%$ was released in $6 \mathrm{~min}, 95 \%$ in $1 \mathrm{hr}$ at $\mathrm{UO}_{2}$ melting temperatures. No analysis was made for the run at clad melting temperature. Release was independent of furnace atmosphere.

Ruthenium and barium release was too low for analysis in the 6-min heating tests. Later tests used higher irradiation levels and 1 hr heating periods, and enough of these materials was released to permit complete analyses. Ruthenium release averaged $25 \%$ and barium $0.13 \%$, with no apparent dependence on temperature or furnace atmosphere.

The deposition of each fission product in the 18-ft long, 0.93 in. ID stainless steel delivery line connecting the furnace to the containment vessel is listed in Table 3. Losses, calculated as percent of material entering the line, averaged about $17 \%$, with ruthenium being the highest and iodine the lowest. The 1 ine was heated to approximately $140^{\circ} \mathrm{C}$. Later tests with simulants showed that fractional losses decreased with larger mass concentrations. (See Table 2.) Flow through this line was laminar at a Reynolds number of about 1200. Residence time in the tube was about 5 sec.

Simulant Tests

The details of simulant generation will not be discussed at length here. A separate report on this topic is being prepared. A brief description follows. The simulant sources were generated by volatilization of stable elements or compounds which had been traced with suitable radioisotopes for analytical purposes. Equilibration of stable and radiochemical nuclides was assured before release. 
Iodine (equilibrated with ${ }^{131}$ I) was prepared before the test by fusing the desired mass of $\mathrm{KI}$ with $\mathrm{K}_{2} \mathrm{Cr}_{2}{ }^{0} 7$ in a low flow rate helium sweep stream. Iodine released from the fusion tube was passed through a $\mathrm{Mg}\left(\mathrm{ClO}_{4}\right)_{2}$ drying tube into clean Pyrex U-tubes held at dry ice temperature. A charcoal backup trap caught the penetrating forms. The drying tube and backup trap were analyzed and discarded. When release was required, the U-tube was warmed and an air carrier gas flow was passed through the tube.

Cesium was released by decomposing $\mathrm{Cs}_{2} \mathrm{CO}_{3}$ (traced with ${ }^{137} \mathrm{Cs}$ ) in a nickel boat at approximately $1000^{\circ} \mathrm{C}$ in the presence of air. The mixture of cesium oxides and cesium metal was undoubtedly converted to cesium hydroxide particles immediately after entering the steam atmosphere either in the $\mathrm{UO}_{2}$ melting furnace, delivery line or containment vessel.

Tellurium oxide (traced with either ${ }^{132} \mathrm{Te}$ or ${ }^{127} \mathrm{Te}$ ) was prepared by the method of Stinchcombe. (18) The oxide was heated in a nickel boat at approximately $1000^{\circ} \mathrm{C}$ in air when needed. Tellurium hydroxide probably was formed when the oxide encountered a steam atmosphere.

Ruthenium oxide (traced with either ${ }^{103} \mathrm{Ru}$ or ${ }^{106} \mathrm{Ru}$ ) was volatilized by heating the metal in air at approximately $1200{ }^{\circ} \mathrm{C}$. Higher oxides were probably released but converted to the dioxide in the steam atmosphere.

Barium (traced with ${ }^{140} \mathrm{Ba}-\mathrm{La}$ ) was released by decomposing $\mathrm{BaCO}_{3}$ in helium on a tantalum filament at greater than $2000{ }^{\circ} \mathrm{C}$. Tantalum at these conditions will reduce barium salts to barium metal, which is volatile at that temperature. Insignificant releases were obtained in the oxide form without reduction. Barium vapors oxidize rapidy in air and would form the hydroxide in steam. 
In many of the tests, as shown in Table 2, the volatilized materials were passed through the $\mathrm{UO}_{2}$ melting furnace and thus were re-exposed to high temperature (estimated at $1000{ }^{\circ} \mathrm{C}$ bulk gas temperature) and the presence of other vapor and particulate materials. Residence time in the hot zone of the furnace was about $0.5 \mathrm{sec}$. In some tests, as shown in $\mathrm{Table} 2$, the $\mathrm{UO}_{2}$ furnace was omitted. Stainless steel cladding was used for the majority of tests, but zircaloy-2 was used in later runs.

The form of the iodine injected into containment was measured by sampling from the delivery line near the vessel inlet. A short $1 / 8$ in. 304 SS tube leading to a Maypack sampled from the delivery tube centerline at isokinetic velocity. Table 4 gives the percent retained on each Maypack component. The irradiated test values are averaged as a group; the same was done for the simulant tests. Considerable differences between tests were noted, with no correlation with aerosol source or furnace atmosphere.

Two factors that affect the ratio of particulate-associated and elemental iodine are known. One is the rate of heating or release of simulant iodine, with more elemental form at high release rates. The other is the total mass released, with again more in the elemental form with higher release masses. The fraction penetrating the first three components and retained on the charcoal bed also depended on the total mass. Table 5 shows these relationships. The irradiated sources, with very low iodine mass, averaged $0.58 \%$ on the charcoal bed. This is believed to be chiefly methyl iodide. A simulant run (Run 28) with about the same iodine mass gave about the same percent on the charcoal. At higher iodine mass releases, (e.g., Run 63) the organic dropped to $0.01 \%$. The intention in the simulant tests was not to introduce precise amounts of each form, but to determine what happened to each form after release. 
Greater than $99 \%$ of the noniodine materials was always retained on the Maypack filter. The most trustworthy analytical results gave greater than $99.9 \%$ on the filter. Exceptions were noted, of course, when the filter was broken or when steam was permitted to condense on the filter. When the latter happened in a few cases, the soluble particles (Cs and $\mathrm{Rb}$ ) were partially leached deeper into the Maypack.

\section{CHANGES IN GAS PHASE}

Of paramount importance in containment studies is the leakage rate of fission prcduct radioactivity to the surrounding environment. This is the source term for meteorological calculations; it is the end term for containment studies. It is the product of three variables:

$$
W_{i}=L_{g} C_{g_{i}} f_{p},
$$

where $w_{i}=$ efflux of species $i$, curies/sec

$\mathrm{L}_{\mathrm{g}}=$ gas leakage rate, $\mathrm{cm}^{3} / \mathrm{sec}$

$\mathrm{C}_{\mathrm{g}_{\mathrm{i}}}=$ concentration of $\mathrm{i}$ in gas, curies $/ \mathrm{cm}^{3}$

$f_{p}=$ penetration fraction, ratio activity leaving leak path to activity entering leak path.

Not much is currently known about the decontamination factor, $f_{p}$. Until proven otherwise, it must be assumed unity. Both $\mathrm{L}_{\mathrm{g}}$ and $\mathrm{C}_{g_{i}}$ are time dependent under most assumed accident conditions, and determining this dependence is a prime objective of containment studies. Leakage rate technology was discussed in considerable detail by Maccary et al. (19) Results of air leakage tests in the CSE are in preparation. Generally the leakage rate is amenable to analysis by straight-forward engineering methods. The gas phase concentration of individual fission products is less so. Many graphs and tables of gas concentration time dependence in the ADF vessels are included in the Appendices and discussed in following sections of this report. 
diminished very slowly for the duration of the test. Methyl iodide concentration remained constant with time, within experimental accuracy limits.

Iodine Form in Containment

Figures B.1 through B.21 show the gas phase iodine concentration as a function of containment time. From these, the fraction existing in each iodine form was calculated at two times (early and late) and reported in Tables 6 and 7 . The percent on each Maypack component 10 min after injection is 1 isted in Table 6. The mean of all irradiated tests and the standard deviation are shown. The same is done for the simulant tests. The reader should recall that the fraction of each iodine form depends on the total mass released. Also, it will be shown in a later section that the removal rate depends on the steam condensation rate, which varied between tests. Therefore, only the trend should be considered. Table 7 gives similar data taken after $5 \mathrm{hr}$ in containment. Table 81 ists the averages in a manner convenient for showing the trend. Clearly, the particulate and elemental forms which predominated at $10 \mathrm{~min}$ had been removed to a large extent after $5 \mathrm{hr}$, leaving methyl iodide as the dominant form.

Mass Transfer Coefficients

Figures B.1 through B.33 were used as a basis for determining the values of the gas phase mass transfer coefficients. As discussed in the Section III, Theoretical Considerations, the slope of the curve at early time depends only on the mass transfer coefficient as 1 ong as the gas concentration remains much larger than the surface equilibrium concentration. Expressed mathematically, this is,

$$
\frac{d\left(1 n C_{G}\right)}{d t}=-K_{G} \frac{A}{V} ; C_{G}>C_{G}^{\prime} \text {. }
$$


The vessel surface area to volume ratio, A/V, was known. The surface roughness was ignored, since it should not be important where gas phase resistance is controlling. The slopes were measured directly from Figures B.1 through B.33 and 1isted in Tables 9 through 16 as concentration half lives. Accuracy was $\pm 15 \%$. Mass transfer coefficients then were easily calculated by Equation (37).

$$
K_{G}=\frac{0.693}{t_{1 / 2} A / V}
$$

Tables 9 through 16 report measured values of $K_{G}$ for total iodine, particulate iodine, elemental iodine, cesium, tellurium, ruthenium, barium, and uranium, respectively, for each run where the material of interest was included in the aerosol. Organic iodides were not included because of their high equilibrium back pressure. The data are grouped according to aerosol source type ( $\mathrm{UO}_{2}$ or simulant) and by Subseries $A$ and $B$, representing high and low steam condensation rates, respectively. The means and standard deviations are listed for each group.

The steam flux is listed for each run. Where it changed during the measurement period, two values are listed. The theoretical values of $K_{G}$ as calculated by Equation (33) are also shown. Finally, the ratios of the observed to calculated values are 1 isted.

The dependence of $K_{G}$ on the steam flux is shown more clearly in Figures B.34 through B.41, where $K_{G}$ is plotted as a function of S/A on linear paper. For comparative purposes, Equations (3) and (33) are plotted as continuous lines.

The mass transfer coefficients are summarized in Table 17. The averages of each test series and aerosol source type are listed. This table shows that the measured values of $K_{G}$ were 
iodine per liter were measured in the condensate in the present work, where the condensate was removed periodically. It should be noted that in tests where the condensate is allowed to accumulate within the vessel, the liquid concentrations would be higher, with possibly higher values of $\mathrm{H}$ and attendant gas phase iodine concentration. However, in a loss-of-coolant accident to a water-cooled reactor, there will probably be sufficient water present to remove elemental iodine to below the concentration of organic forms.

DISTRIBUTION WITHIN CONTAINMENT

By mass balance on the entire containment vessel (for a given FP species) assuming instantaneous release,

$$
\frac{d m_{t}}{d t}=-B^{-} C_{L},
$$

where $m_{t}=$ total moles of FP species within vesse1. The right term is simply the mass leaving the vessel in the condensate, which was periodically withdrawn from the sump in the experiments. The assumption is made that material in the sump condensate was not involved in further transport processes.

A mass balance within the vessel gives

$$
\text { BSC }_{L}+\frac{d m_{g}}{d t}+\frac{d m_{\ell}}{d t}+\frac{d m_{S}}{d t}=0,
$$

where $\mathrm{m}_{\mathrm{g}}=$ moles in gas phase

$$
\begin{aligned}
& m_{l}=\text { moles in liquid film } \\
& m_{s}=\text { moles reacted with solid surfaces }
\end{aligned}
$$

Equation (40) simply states that the fission product must be distributed between four locations: the condensate in the sump, the gas phase, the liquid film, or reacted with solid surfaces. 
The time dependence of the first and second terms in Equation (40) was measured experimentally. Typical results are shown in Figures B.42 through B.52, where the first two terms of the equation are shown as curves labeled "in condensate sump" and "in gas phase," respectively. The third and fourth terms were not measured but were lumped and estimated together by using Equation (40). The combined term is plotted as a broken line labeled "on surfaces" in the figures and represents both the material in the liquid film adhering to the vessel surfaces and the amount reacted with the solid surfaces. It should be noted that the total fission product or simulant mass is represented. For example, total iodine is shown, not elemental or particulate only. The material balance was closed at the termination of the test by decontamination of the surfaces. What was not recovered was considered to have reacted with the paint or stainless steel.

The six aerosol materials used in the ADF tests (I, Cs, Te, $\mathrm{Ru}, \mathrm{Ba}, \mathrm{U})$ can be divided into two groups according to the manner in which they were distributed within containment with time. All were injected into the gas phase, and all showed an initial rapid transfer from the gas to the liquid film covering the vessel surfaces. Differences in water solubility caused a division in the ensuing transport. Iodine and cesium, highly soluble in the condensate film, were transported by the flowing liquid film to the sump and were withdrawn from the vessel. The other materials ( $\mathrm{Te}, \mathrm{Ru}, \mathrm{Ba}, \mathrm{U}$ ) accompanied the liquid film flow to only a slight extent. Filtering the sump effluent showed these latter materials to be largely filterable. It is unlikely that these particulate materials reacted with the solid surfaces of the vessel interior, but rather were held by physical forces. The liquid film, averaging on $1 \mathrm{y} \sim 0.01 \mathrm{~cm}(100 \mu)$ thick, flowed at an average velocity of $0.5 \mathrm{~cm} / \mathrm{sec}$ for the Series $A$ runs and 
$0.07 \mathrm{~cm} / \mathrm{sec}$ for series B runs. This is in the laminar region, and viscous drag on particles attached to the wall would be sma11. Chapman (23) discussed flowing films in uniform steam condensing systems on the basis of mass and momentum transfer and showed that the average film thickness was proportional to the vertical height to the one-fourth power. The average film velocity is proportional to the one-half power of the height.

This suggests that liquid film characteristics are not strongly affected by vertical wall height. For example, at the same uniform condensing steam flux, the average film thickness in a large power reactor containment vessel would be only about twice that in the ADF vessels and film velocity about four times that in the ADF vessels.

Figures B.42 through B.52 show that there were no significant differences between simulant and real fission product behavior in the manner in which they were transported by liquid film flow. Steam flux did affect the relative positions of the curves, as predicted by the ADF model and as shown by differences between Series $A$ and $B$ tests.

Tables 20 through 25 list the percentage distribution between gas phase, condensate sump, and vessel surfaces (1iquid film plus solid surfaces) at the end of the $5 \mathrm{hr}$ containment period. Corrections were made to account for the amount sampled. The reader should recall that at $5 \mathrm{hr}$ the gas-borne iodine was largely organic forms (see Table 8), while the 1 ast two columns in Table 20 are largely nonorganic forms. Also, the distribution depends on the condensation rate, with more retained on the ves sel walls at low steam fluxes.

In obtaining data such as 1 isted in Tables 20 through 25 , sample analytical accuracy is very important. Higher confidence is placed on the analyses of simulant samples both because of the simpler gamma energy spectra and because the initial aerosol activity was sufficiently high to permit accurate analyses at long containment times. 
Tables 20 and 21 show that Run IA 40 gave anomalous results for iodine and cesium. These two materials were held up on the vessel surfaces to a much greater extent in this run than in any other. It is possible that condensate sample analyses were in error for this test, which would give the reported high value on the vessel surfaces. The aerosol source for this test was irradiated $\mathrm{UO}_{2}$ heated to 1500 to $1700{ }^{\circ} \mathrm{C}$ for $1 \mathrm{hr}$, and it is conceivable that the normally soluble iodine and cesium were occluded within insoluble $\mathrm{UO}_{2}$-stainless oxide particles during the slow, low-temperature release. This point should be studied by further tests. It should be noted, however, that the removal rate from the gas phase was not anomalous.

Table 26 lists the average percent distribution and standard deviation between tests for each isotope. Comparison of irradiated source tests with simulant tests shows the two agree within one standard deviation for the percent in the sump and on the surfaces. Differences in the gas phase are to be expected for iodine because of the different fractions of organic iodine released, as shown in Table 8 . Differences between irradiated and simulant noniodine fission products in the gas phase may not be as great as indicated in Table 26 because the analytical error in the irradiated source samples was large for the very low concentrations measured after $5 \mathrm{hr}$ containment time. Analyses of simulant test samples were more accurate because sufficient activity was used to allow accurate measurements after five orders of magnitude decrease in gas concentration. FORM IN CONDENSATE

Samples of the condensate withdrawn from the vessels at various times were filtered and the filter and filtrate were analyzed separately. The filters were washed with $100 \mathrm{ml}$ of demineralized water. Tables 27 and 28 ist the percentage removed by filtering, which is an indication of the materials' 
water solubility. Several factors preclude high confidence in these analyses. First, the material in the sump may be more soluble than that remaining on the vessel walls. That is, the sump contains material already washed off the walls, suggesting that remaining materials may be less soluble. Second, some materials were present in very low amounts and presence of other gamma emitters lowered analytical accuracy. Third, a change in procedure resulted in the irradiated source samples being filtered through cellulose acetate membranes (Gelman GM-4, $0.8 \mu$ pore size) while fibrous filters (Gelman Type A) were used for simulants. The membrane filters are more efficient for filtering liquids with small particles. In spite of these experimental problems, the trend is clear: iodine and cesium were very soluble, barium and tellurium slightly soluble, and ruthenium and uranium very insoluble.

One test (IA 40) gave results indicating that iodine and cesium were fairly insoluble for that run. This was the test where irradiated $\mathrm{UO}_{2}$ was held at SS-clad melting temperature for $1 \mathrm{hr}$. It is conceivable that iodine and cesium were occluded within insoluble $\mathrm{Fe}-\mathrm{Ni}-\mathrm{Cr}-\mathrm{U}$ particles and only slowly leached out. The clad-UO 2 fume should have been rich in stainless steel oxides at that temperature, compared with all other tests at the $\mathrm{UO}_{2}$ melting point where $\mathrm{UO}_{2}$ is more volatile.

In a few tests, the condensate was heated to boiling and sparged with air to determine whether the iodine could be released. In no case was there a detectable loss of iodine. Samples left open to the atmosphere for several days also did not lose detectable amounts of iodine.

The filtered condensate was extracted with benzene, then the benzene fraction was back-extracted with caustic solution. Table 29 shows a result for two times: an early sample and a later one. Extraction was performed 13 min after the sample 
was taken. It appears that iodine in the early condensate was greater than $99 \%$ ionic, $0.02 \%$ organic, and approximately $0.2 \%$ elemental, with later samples having somewhat higher fractions of organic and elemental. Second extractions made on aliquots that were allowed to stand 2 to $3 \mathrm{hr}$ showed no changes. This showed that, once in the condensate, no change of forms occurred.

OVERALL MATERIAL RECOVERY

Obtaining good material balances in containment experiments is difficult because the material is spread over large areas, some of which are impossible to decontaminate without destroying the surface. The painted aerosol tank, for example, had $8 \mathrm{~m}^{2}$ of phenolic paint on its interior. The method used to decontaminate the paint was long-term steaming that, since the surfaces were all condensing, gave a washing action. Chemical reagents were not used in order not to change the surface characteristics from test to test.

Table 30 gives the material recovery, expressed as percent of material injected to the containment vessel that was accounted for by analysis. Good recovery of the soluble materials iodine and cesium was obtained. The insoluble materials tellurium, ruthenium, and barium gave poor recovery, since they were left, to a large extent, on the vessel surfaces. It should be noted that percent accounted for would be higher if the calculation had been based on the amount heated rather than that injected.

Table 30 shows that, in general, better material balances were obtained with the simulant materials than with the irradiated. This is partly due to more accurate analyses and partly because some of the simulant tests were conducted in the stainless steel vessels, which was more easily decontaminated. In the authors' opinion, the inability to close the material balance at $100 \%$ does not affect the conclusions made in this report. 
MISCELLANEOUS OBSERVATIONS

Effect of Mass Concentration

The mass of iodine injected into containment was varied from one microgram (Run SA 28) to $10^{5}$ microgram (Run SB 63). No effect on transport behavior was discernible for any given iodine form. However, the fraction of each iodine form injected did depend on total mass. This is shown in Table 8 . Low mass injections gave high organic iodine fractions. The irradiated $\mathrm{UO}_{2}$ source tests, which were low mass releases, fit the trend very well.

Noniodine aerosol mass injections were not varied appreciably in these tests, except that the simulants were about $10^{3}$ higher than the irradiated source materials. No mass effect was observed.

The ratio of $\mathrm{UO}_{2}$ to fission product or simulant material heated was varied over a large range. The trace-irradiated sources contained about $1.5 \times 10^{8} \mathrm{~g} \mathrm{UO}_{2}$ per gram of iodine. In Run SA 28 the ratio was $7 \times 10^{7}$, in most of the runs it was approximately $7 \times 10^{4}$, and in Run SB 63 it was $7 \times 10^{2}$. The ratio for $10^{4} \mathrm{MWd} / \mathrm{T}$ irradiated fuel is $1.5 \times 10^{4}$. No effect on transport behavior was noted.

Effect of Aerosol Complexity

The aerosol released from heated irradiated $\mathrm{UO}_{2}$ contained the full fission product spectrum. Most of the simulant tests used only one or two components. Table 31 compares the transport behavior of iodine in a simple aerosol consisting of iodine plus SS-UO $\mathrm{U}_{2}$ fume with the average of the irradiated tests and Run SB 53, which had five simulated components plus SS-UO ${ }_{2}$. The agreement is excellent, indicating that a complex aerosol is not required for experiments on iodine transport in containment systems with conditions similar to those used in the ADF tests. 
Effect of $\mathrm{UO}_{2}$ Cladding Material

The cladding used in all the irradiated $\mathrm{UO}_{2}$ tests was 304 SS. Likewise, all but one simulant test used stainless steel cladding. In Run SB 64, Zircaloy-2 cladding was used. Table 32 compares the transport behavior of iodine in this single test with the average of three comparable simulant tests that used stainless steel cladding. The agreement is good, with no result for the ircaloy test being outside the range of the stainless steel tests.

Fresh Versus Aged Paint

The carbon steel PAT vessel was coated with Phenoline* 300 orange primer and two Phenoline 300 gray cover coats about three months prior to its first use in a steam atmosphere. Table 33 compares the significant measurements for the first test with two later tests. All conditions were nearly identical except paint age.

The only significant difference seen is that more iodine stayed on the vessel walls during the first test $(27 \%$ versus $7 \%$ ). This is substantiated by the lower material recovery ( $50 \%$ versus $100 \%$ and $94 \%$ ) and suggests that the reaction rate of iodine in the condensate film with the fresh paint was higher than with paint previously exposed to steam and low concentrations of iodine. This is in agreement with the work of Genco et al., (24) who postulate a second-order irreversible reaction of iodine on reactive sites in the paint. After the first test there was no further significant change. This is reason$a b l e$ if only the surface of the paint reacts. Diffusion of iodine to the interior of the paint would be very low in the ADF tests where the concentration of iodine in the steam condensate film decreased very rapidly.

* Modified phenolic coating, Carboline company, St. Louis, Missouri. 
It is important to note that no effect can be seen on organic iodine behavior. Methyl iodide was neither formed nor destroyed, within the detection limits of these experiments. Sampling Through Long Lines

A11 gas samples reported were taken by Maypacks inserted directly into the containment atmosphere. The steam, air, and aerosol mixture passed directly into the Maypack without traversing an inlet tube or check valve. A few samples were taken through a $20-\mathrm{ft}$ long tube to determine the error introduced by the inlet line. The tube was 0.43 in. ID $304 \mathrm{SS}$ with three $90^{\circ}$ bends of 3 in. radius. The line contained one $1 / 2$ in. bal1 valve. It was electrically heated to slightly above containment atmosphere temperature, as was the Maypack on the downstream end. The flow rate was $0.5 \mathrm{scfm}$ of air, the same as used in the normal sampling procedure. The Reynold's number through the tube was 1600 , indicating streamline flow but near the turbulent region.

Table 34 tabulates some typical results along with the normal sample taken concurrently. The agreement is surprisingly good, suggesting that long sampling lines can give usable results if condensation is prevented and the flow is kept in the high streamline region.

Effect of Agitation

As the tests progressed it became apparent that agitating the atmosphere inside the containment vessel had a significant effect on transport from the gas phase to the surfaces. This should not have been surprising in view of the discussion on diffusional transport in Section III. When the agitator was run, the gas velocity past the vessel surfaces was increased, thus increasing the diffusional mass transfer coefficient, $K_{D}$ (Equation 11). In Subseries A tests (high steam condensation 


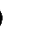


rates) the effect of agitation would be less noticeable because the bulk fluid flux term, $N_{B} R T / P$, was much greater than $K_{D}$. This can be seen by comparing tests SA 21 and SA 23 . Both tests were conducted under essentially duplicate conditions except the agitator was run in SA 21 for the first 43 min; it was not run in SA 23. Table 9 shows that the ratio of measured overall mass transfer coefficient, $K_{G}$, to that predicted by the ADF mode 1 [Equation (36)] was only $12 \%$ higher for the case where the agitator was run.

In Subseries B tests, where the steam condensation rate was low, the effect of agitation was more apparent. In most cases where the agitator was run, $\mathrm{K}_{\mathrm{G}}$ was higher than the $\mathrm{ADF}$ model predicted.

One test was made where the agitator was run for $27 \mathrm{~min}$, then stopped, then run for the next $153 \mathrm{~min}$, then stopped. Although this test (SO 66) was conducted in an ambient air atmosphere, the rate of decrease of gas phase concentration due to transport to the dry vessel surfaces should reflect the differences in gas velocity caused by agitation. Figure 7 shows the results. Transfer rate out of the gas phase was definitely higher during the times that the agitator was running. Inertial effects prevented sharp time changes in gas velocity, but the effect is clearly displayed.

Tables 1 and 2 show which tests used the agitator. None of the irradiated source tests (Series I) used the agitator. In about half of the simulant tests, the agitator was run, usually only during the sampling period.

The net effect of the inconsistancy of agitator usage on comparing irradiated with simulant aerosol behavior in this report is that even closer agreement would have been obtained had the agitator usage been consistant. 


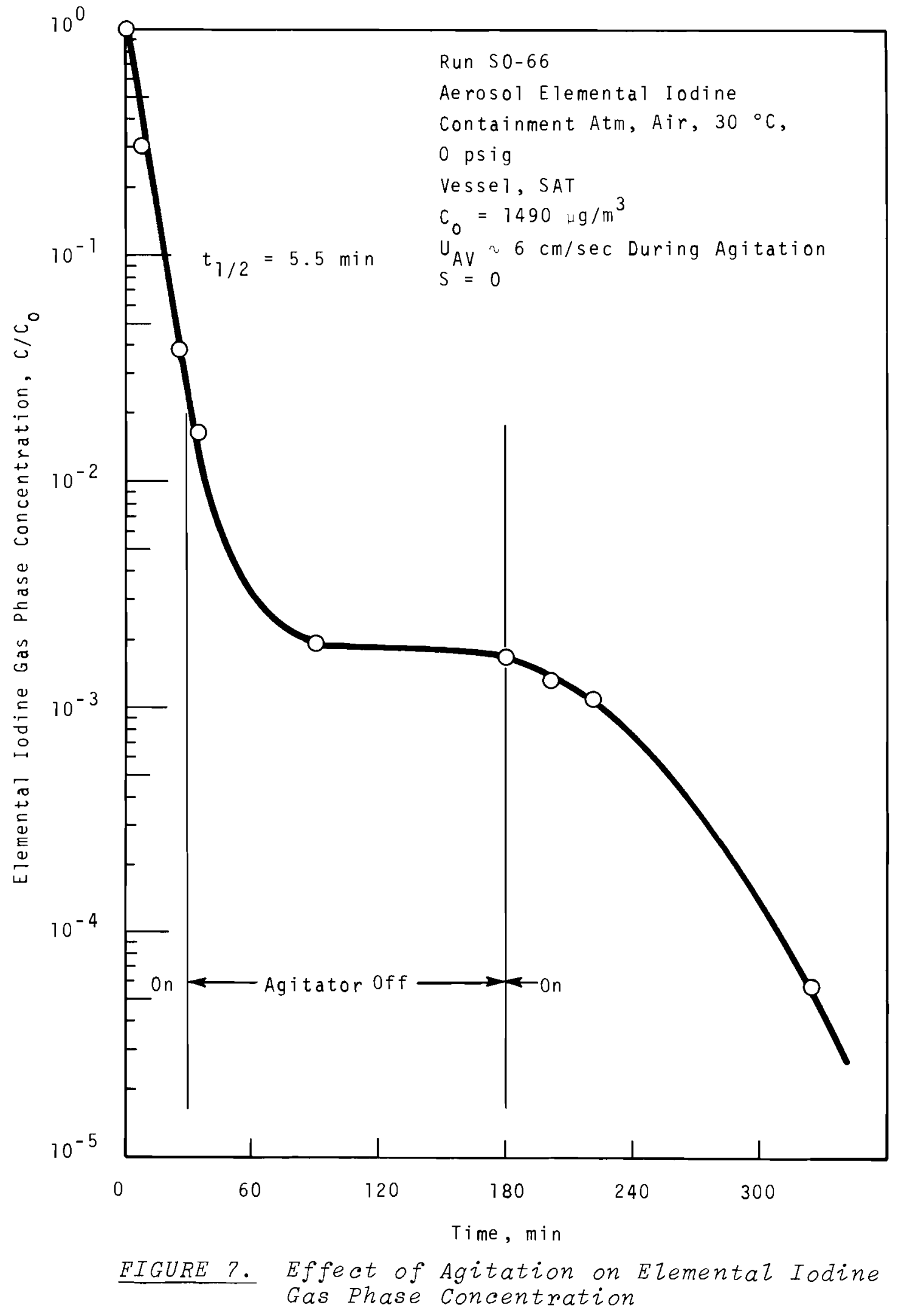




\section{ACKNOWLEDGEMENTS}

Many members of the staff of the Reactor Safeguards Experiments Unit Staff contributed to the success of this investigation by obtaining and installing the equipment, performing the tests, analyzing the samples, and correlating the results. The authors especially wish to recognize M. F. Dreher, J. L. Manuel, D. A. Nelson and R. M. Tanner, Jr. for their enthusiasm and consistant attention to experimental details. Professor J. G. Knudsen of Oregon State University provided valuable assistance in the development of the theoretical model. 
VII. NOMENCLATURE

$\bar{C}=\quad C / C_{0}$, dimensionless gas phase concentration

C, concentration, mole $/ \mathrm{cm}^{3}$

$C_{0}$, concentration at $t=0, \mathrm{~mole} / \mathrm{cm}^{3}$

$\overline{\mathrm{T}}^{\mathrm{O}}=\mathrm{Dt} / \mathrm{a}^{2}$, dimensionless time

D, diffusion coefficient, $\mathrm{cm}^{2} / \mathrm{sec}$

a, vessel characteristic dimension, $\mathrm{cm}$

$t$, time after release, sec

$\mathrm{N}_{i}$, fission product flux toward surface, mole $\mathrm{sec}^{-1} \mathrm{~cm}^{-2}$

$\mathrm{N}_{S}$, steam flux toward surface, mole $\mathrm{sec}^{-1} \mathrm{~cm}^{-2}$

$X_{i}$, mole fraction of fission product in bulk gas phase

$K_{D}$, mass transfer coefficient for diffusion through gas boundary layer $\mathrm{cm} / \mathrm{sec}$

A, vessel surface area, $\mathrm{cm}^{2}$

$\mathrm{C}_{\mathrm{G}}$, gas phase concentration, mole $/ \mathrm{cm}^{3}$

$C_{G}$, gas phase concentration in equilibrium with liquid, mole $/ \mathrm{cm}^{-3}$

$\mathrm{V}$, vesse1 volume, $\mathrm{cm}^{3}$

$\mathrm{R}, \quad$ gas constant, $\mathrm{cm}^{3} \mathrm{~atm} / \mathrm{mol}{ }^{\circ} \mathrm{K}$

$\mathrm{T}$, temperature, absolute, ${ }^{\circ} \mathrm{K}$

$\mathrm{P}, \quad$ total pressure, absolute, atm

$H=C_{G} / C_{L}$, dimensionless gas-1iquid partition coefficient

$C_{L}$, concentration in liquid film, mole/ $/ \mathrm{cm}^{-3}$

$K_{G}$, overall gas phase mass transfer coefficient, $\mathrm{cm} \mathrm{sec}^{-1}$

$\mathrm{S}$, steam condensation rate, $\mathrm{cm}^{3}$ (1iquid) $\mathrm{sec}^{-1}$

$\mathrm{R}_{\mathrm{L}}$, liquid-solid reaction rate constant, $\mathrm{cm} \mathrm{sec}-1$

$B=C_{\dot{L}} / C_{L}$, dimensionless ratio of liquid film to sump concentration

$\mathrm{C}_{\hat{\mathrm{L}}}$, sump concentration, mole $\mathrm{cm}^{-3}$

$\mathrm{L}$, volume of liquid film on surfaces, $\mathrm{cm}^{3}$

$v_{D}$, deposition velocity, $\mathrm{cm} / \mathrm{sec}$

$\mathrm{M}$, molecular weight, $\mathrm{g}$ mole $\mathrm{e}^{-1}$ 


\section{NOMENCLATURE (contd)}

$\nabla C_{i}$, gas phase concentration gradient across boundary layer, mole $\mathrm{cm}^{-3} \mathrm{~cm}^{-1}$

$j_{D}$, dimensionless Colburn factor

$\mathrm{P}_{\mathrm{BM}}$, log mean pressure of inert gas at phase boundary and in bulk fluid, atm

$\mathrm{U}_{\mathrm{av}}$, gas velocity in bulk fluid, $\mathrm{cm} \mathrm{sec}^{-1}$

$S_{C}$, Schmidt number, $\mu / \rho D$

$\mu$, fluid film viscosity, $\mathrm{g} \mathrm{sec}^{-1} \mathrm{~cm}^{-1}$

$\rho$ fluid film density, $\mathrm{g} \mathrm{cm}^{-3}$

$\operatorname{Re}=\ell U_{\mathrm{av}} \rho / \mu$, dimensionless Reynold's number

$\ell$, characteristic length, $\mathrm{cm}$

$\mathrm{k}_{r}$, aerosol release rate, $\mathrm{g}$ mole $\mathrm{sec}^{-1}$

$\mathrm{m}_{t}$, total mass of FP species, mole

$\mathrm{m}_{\mathrm{g}}$, mass of FP species in gas phase, mole

$\mathrm{m}_{\ell} \quad$ mass of FP species in liquid film, mole

$\mathrm{m}_{\mathrm{s}}$, mass of FP species reacted with surfaces, mole

$\mathrm{N}_{\mathrm{B}}$, flux of bulk gas to walls, mole $\mathrm{sec}^{-1} \mathrm{~cm}^{-2}$ 


\section{REFERENCES}

1. G. J. Rogers. Program for Containment Systems Experiment, HW-83607, September 1964 .

2. R. K. HizZiard and J. D. McCormack. "Fission Product Simuzation in the Containment Systems Experiment, "paper 27, International Symposium on Fission Product Release and Transport, Oak Ridge, April 5-7, 1965, CONF-650407, pp. 588602 .

3. B. M. Johnson. Containment Systems Experiment, Part III, Mathematical Models of Pressure-Temperature Transients, BNWL-233, Pacific Northwest Laboratory, Richland, Washington. May 1966 .

4. N. P. Wilburn and L. D. Coffin. The Combination of on-Line Analysis with Colzection of Murticomponent Spectra in $A$ $\overline{P D} \overline{P-7}, B N W L-C C-700$, Pacific Northwest Laboratory, Richland, Washington. July 1966.

5. R. B. Bird, W. E. Stewart, and E. N. Lightfoot. Transport Phenomena, John Wiley and Sons, Inc., New York. 1960. 1st Edition.

6. R. E. Treybal. Mass Transfer Operations, McGraw-Hizl Book Company, Ine., New York. 1955. 1st Edition.

7. T. K. Sherwood and R. L. Pigford. Absorption and Extraction, McGraw-Hizl Book Company, Inc., New York. 1952. 2nd Edition.

8. J. H. Perry. Chemical Engineer's Handbook, McGraw-Hizl Book Company, Inc., New York, 1950, pp.540-547. 3rd Edition.

9. W. B. Cottrel2. Nuclear Safety Program Semiannual Progress Report for Period Ending June 30, 1965, ORNL-3843, oak Ridge National Laboratory, pp. 117-123. September 1965.

10. G. M. Watson, et al. Effects of Containment Size on Fission Product Behavior, ORNL-4033, Oak Ridge National Laboratory. January 1967. 


\section{REFERENCES (contd)}

11. D. L. Morrison et al. An Evaluation of the Applicability of Existing Data to the Analytical Description of $A$ Nuclear-Reactor Accident, BMI-1779, pp. 155-196. August 1966 .

12. D. I. Morrison et al. An Evaluation of the Applicability of Existing Data to the Analytical Description of $A$ Nuclear-Reactor Accident, Quarterly Progress Report for october through December, 1966, BMI-1790. January 1, $\overline{1} 967$.

13. W. I. Megaw and F. G. May. The Behavior of Iodine Released in Reactor Containers, AERE-R3781. July 1961.

14. J. F. Croft and R. S. Iles. Experimental Release of Radioiodine in the Zenith Reactor Containment, AEEW-R-172. September 1962 .

15. P. Goldsmith et al. The Role of Diffusiophoresis in the scavenging of Radioactive Particles from the Atmosphere, $A E R E-R-4097$. June 1962 .

16. A. Einstein. Ann. Physik, vol. 17, p. 549. 1905.

17. J. D. McCormack and R. K. Hizliard. "Natural Removal of Fission Products Released from UO 2 Fuel in Condensing Steam Environments," paper 8, International Symposium on Fission Product Re lease and Transport, Oak Ridge, April 57, 1965. CONF-650407.

18. R. A. Stinchecombe. Generation of Telzurium Aerosols and Preliminary Filtration Experiments, AERE-M-1130. January 1963.

19. R. R. Maccary et al. Leakage Characteristics of Steel Containment Vessels and the Analysis of Leakage Rate Determinations, TID-20583. May 1964 .

20. V. Griffiths. The Removal of Iodine from the Atmosphere by Sprays," AHSB (S) R 45. January 1963.

21. I. C. Watson et al. Iodine Containment by Dousing in NPD-II, CRCE-979. october 1960.

22. A. E. J. Eggleton. A Theoretical Examination of IodineWater Partition Coefficients, AERE-R-4887. February 1967 . 


\section{REFERENCES (contd)}

23. A. J. Chapman. Heat Transfer, The MacMizzan Co., New York, p. 285. 1960 .

24. J. M. Genco et al. Fission Product Deposition and its Enhancement Under Reactor Accident Conditions, $B M I-X-$ 10202 . JuZy 1967 . 
APPENDIX A

TABLES 1 THROUGH 34 

TABLE 1. Series I Experimental Conditions (a) (Irradiated vo Sources)

\begin{tabular}{|c|c|c|c|c|c|c|c|c|c|c|c|c|c|}
\hline \multirow[b]{3}{*}{$\begin{array}{l}\text { Run } \\
\text { No. }\end{array}$} & \multirow{3}{*}{\multicolumn{2}{|c|}{$\begin{array}{r}n v t, \\
\mathrm{n} / \mathrm{cm}^{2} \\
\end{array}$}} & \multicolumn{6}{|c|}{ Furnace Conditions } & \multicolumn{5}{|c|}{ Containment Conditions } \\
\hline & & & \multirow[b]{2}{*}{$\underline{{ }^{\circ} \mathrm{C}},{ }^{\mathrm{Temp}},(\mathrm{b})$} & \multirow[b]{2}{*}{$\begin{array}{c}\text { Time at } \\
\text { Temp, } \\
\text { min } \\
\end{array}$} & \multicolumn{4}{|c|}{ Atmosphere, $\%$} & \multirow{2}{*}{\multicolumn{2}{|c|}{$\begin{array}{c}\text { Temp, } \\
{ }^{\circ} \mathrm{C}\end{array}$}} & \multirow[b]{2}{*}{$\begin{array}{l}\text { Gage } \\
\text { Pressure, } \\
\text { in. Hg } \\
\end{array}$} & \multicolumn{2}{|c|}{ Steam Fiux } \\
\hline & & & & & $\stackrel{-1}{<}$ & 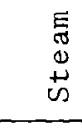 & $I^{N}$ & $\dot{z}$ & & & & $\frac{t<1 \mathrm{hr}}{\mathrm{g} / \mathrm{sec} / \mathrm{m}^{2}}$ & $\frac{t>1 \mathrm{hr}}{\mathrm{g} / \mathrm{sec} / \mathrm{m}^{2}}$ \\
\hline IA 26 & & $\times 10^{16}$ & $\mathrm{~m} \cdot \mathrm{p}$ & 6 & 100 & 0 & 0 & 0 & $70 \pm$ & $\pm 15^{(c)}$ & 0 to -3 & 0.18 & 0.12 \\
\hline IA 32 & 1 & $\times 10^{17}$ & $m \cdot p$ & 6 & 0 & 100 & 0 & 0 & $82 \pm$ & \pm 4 & -1 to -4 & 0.45 & 0.32 \\
\hline IA 33 & 1 & $\times 10^{17}$ & $\mathrm{~m} \cdot \mathrm{p}$ & 16 & 20 & 80 & 0 & 0 & $82 \pm$ & \pm 4 & 0 to -2 & 0.40 & 0.29 \\
\hline IA 39 & 2 & $\times 10^{17}$ & $\mathrm{~m} \cdot \mathrm{p}$. & 60 & 20 & 80 & 0 & 0 & $82 \pm$ & \pm 4 & -1 to -3 & 0.52 & 0.29 \\
\hline IA 40 & 2 & $\times 10^{17}$ & $\begin{array}{l}1300- \\
1800\end{array}$ & 60 & 20 & 80 & 0 & 0 & $84 \pm$ & \pm 4 & -1 to -3 & 0.42 & 0.28 \\
\hline I B 41 & 2 & $\times 10^{17}$ & $\mathrm{~m} \cdot \mathrm{p}$ & 60 & 20 & 80 & 0 & 0 & $84 \pm$ & \pm 8 & 0 to -2 & 0.035 & 0.035 \\
\hline IB 42 & 2 & $\times 10^{17}$ & $\mathrm{~m} \cdot \mathrm{p}$ & 60 & 0 & 90 & 1 & 9 & $84 \pm$ & \pm 8 & 0 to -3 & 0.058 & 0.058 \\
\hline
\end{tabular}

(a) All series I tests made in Painted Aerosol Tank (PAT) with equimolar steam-air atmosphere. No mechanical agitation.

(b) m.p. means UO 2 was melted.

(c) Trouble with inzeaking air. 
TABLE 2. Series S Experimental Conditions ${ }^{(\alpha)}$ (Simulant Sources)

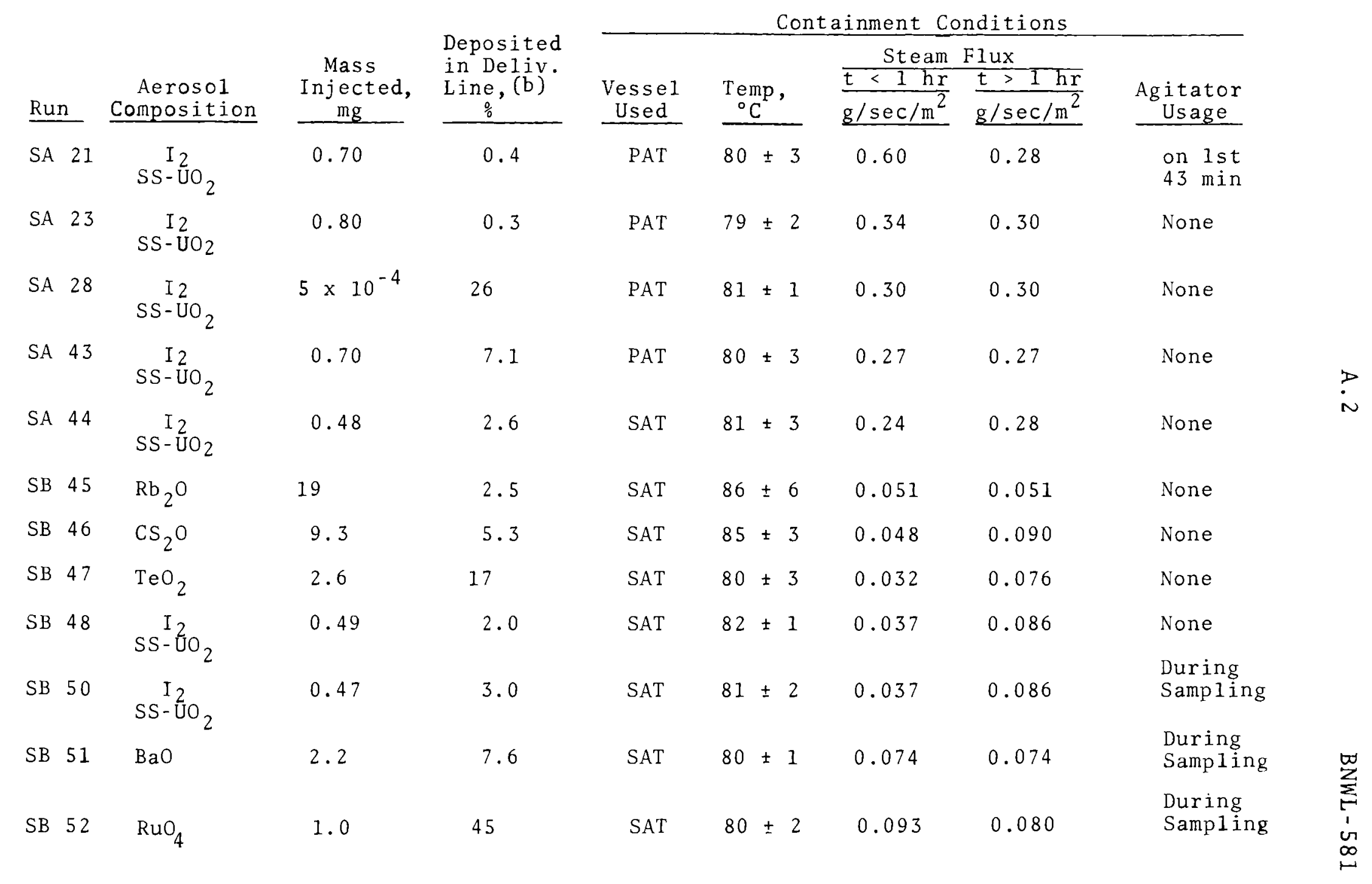


TABLE 2. (Contd)

\begin{tabular}{|c|c|c|c|c|c|c|c|c|c|}
\hline \multirow{2}{*}{\multicolumn{2}{|c|}{ Run }} & \multirow[b]{2}{*}{$\begin{array}{c}\text { Aerosol } \\
\text { Composition } \\
\end{array}$} & \multirow[b]{2}{*}{$\begin{array}{c}\text { Mass } \\
\text { Injected, } \\
\mathrm{mg}\end{array}$} & \multirow[b]{2}{*}{$\begin{array}{l}\text { Deposited } \\
\text { in Deliv. } \\
\text { Line, (b) } \\
\frac{o}{0} \\
\end{array}$} & \multicolumn{4}{|c|}{ Containment Conditions } & \multirow[b]{2}{*}{$\begin{array}{c}\text { Agitator } \\
\text { Usage } \\
\end{array}$} \\
\hline & & & & & $\begin{array}{l}\text { Vesse1 } \\
\text { Used } \\
\end{array}$ & $\begin{array}{l}\text { Temp } \\
{ }^{\circ} \mathrm{C}\end{array}$ & $\frac{\text { Steam }}{\mathrm{t}<\mathrm{g} / \mathrm{hr}}$ & $\begin{array}{l}\text { F1ux } \\
\frac{\mathrm{t}>1 \mathrm{hr}}{\mathrm{g} / \mathrm{sec} / \mathrm{m}^{2}}\end{array}$ & \\
\hline SB & 53 & $\mathrm{I}_{2}$ & 0.91 & 3.3 & SAT & $80 \pm 2$ & 0.067 & 0.090 & During \\
\hline & & $\mathrm{CS}_{2} \mathrm{O}$ & 0.53 & 11 & & & & & Sampling \\
\hline & & $\mathrm{RuO}_{4}$ & 1.2 & 15 & & & & & \\
\hline & & $\mathrm{TeO}_{2}$ & 0.73 & 3.0 & & & & & \\
\hline & & $\begin{array}{l}\mathrm{BaO} \\
\mathrm{SS}-\mathrm{UO}_{2}\end{array}$ & 0.70 & 5.0 & & & & & \\
\hline SB & 60 & $\begin{array}{c}\mathrm{I}_{2} \\
\mathrm{SS}-\mathrm{UO}_{2}\end{array}$ & 0.70 & 12 & SAT & $80 \pm 1$ & 0.031 & 0.067 & $\begin{array}{l}\text { Steam Jet } \\
\text { Injector }\end{array}$ \\
\hline SB & 61 & $\begin{array}{c}\mathrm{I}_{2} \\
\mathrm{SS}-\mathrm{UO}_{2}\end{array}$ & 1.35 & 21 & SAT & $82 \pm 2$ & 0.042 & 0.055 & Intermittent \\
\hline SB & 63 & $\begin{array}{c}\mathrm{I}_{2} \\
\mathrm{SS}-\mathrm{UO}_{2}\end{array}$ & 95 & 0.1 & SAT & $81 \pm 2$ & 0.042 & 0.042 & on entire run \\
\hline SB & 64 & $\begin{array}{c}\mathrm{I}_{2} \\
\mathrm{Zr}-\mathrm{UO}_{2}\end{array}$ & 0.97 & 1.3 & SAT & $82 \pm 2$ & 0.053 & 0.053 & on entire run \\
\hline SB & 74 & $\mathrm{I}_{2}$ & 46.8 & 0.9 & SAT & $81 \pm 2$ & 0.045 & 0.045 & $\begin{array}{l}\text { During } \\
\text { Sampling }\end{array}$ \\
\hline SB & 78 & $\mathrm{Cs}_{2} \mathrm{I}_{2} \mathrm{O}$ & $\begin{array}{l}0.87 \\
2.4\end{array}$ & 12.3 & SAT & $80 \pm 3$ & 0.045 & 0.065 & $\begin{array}{l}\text { During } \\
\text { Sampling }\end{array}$ \\
\hline
\end{tabular}

(a) AIZ Series $S$ Tests were with equimolar steam-air containment atmosphere at -1 in. Hg gage pressure.

(b) Percent of mass entering the delivery zine. 
TABLE 1. Series I Experimental Conditions (a) (Irradiated vo Sources)

\begin{tabular}{|c|c|c|c|c|c|c|c|c|c|c|c|c|c|}
\hline \multirow[b]{3}{*}{$\begin{array}{l}\text { Run } \\
\text { No. }\end{array}$} & \multirow{3}{*}{\multicolumn{2}{|c|}{$\begin{array}{r}n v t, \\
\mathrm{n} / \mathrm{cm}^{2} \\
\end{array}$}} & \multicolumn{6}{|c|}{ Furnace Conditions } & \multicolumn{5}{|c|}{ Containment Conditions } \\
\hline & & & \multirow[b]{2}{*}{$\underline{{ }^{\circ} \mathrm{C}},{ }^{\mathrm{Temp}},(\mathrm{b})$} & \multirow[b]{2}{*}{$\begin{array}{c}\text { Time at } \\
\text { Temp, } \\
\text { min } \\
\end{array}$} & \multicolumn{4}{|c|}{ Atmosphere, $\%$} & \multirow{2}{*}{\multicolumn{2}{|c|}{$\begin{array}{c}\text { Temp, } \\
{ }^{\circ} \mathrm{C}\end{array}$}} & \multirow[b]{2}{*}{$\begin{array}{l}\text { Gage } \\
\text { Pressure, } \\
\text { in. Hg } \\
\end{array}$} & \multicolumn{2}{|c|}{ Steam Fiux } \\
\hline & & & & & $\stackrel{-1}{<}$ & 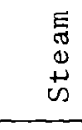 & $I^{N}$ & $\dot{z}$ & & & & $\frac{t<1 \mathrm{hr}}{\mathrm{g} / \mathrm{sec} / \mathrm{m}^{2}}$ & $\frac{t>1 \mathrm{hr}}{\mathrm{g} / \mathrm{sec} / \mathrm{m}^{2}}$ \\
\hline IA 26 & & $\times 10^{16}$ & $\mathrm{~m} \cdot \mathrm{p}$ & 6 & 100 & 0 & 0 & 0 & $70 \pm$ & $\pm 15^{(c)}$ & 0 to -3 & 0.18 & 0.12 \\
\hline IA 32 & 1 & $\times 10^{17}$ & $m \cdot p$ & 6 & 0 & 100 & 0 & 0 & $82 \pm$ & \pm 4 & -1 to -4 & 0.45 & 0.32 \\
\hline IA 33 & 1 & $\times 10^{17}$ & $\mathrm{~m} \cdot \mathrm{p}$ & 16 & 20 & 80 & 0 & 0 & $82 \pm$ & \pm 4 & 0 to -2 & 0.40 & 0.29 \\
\hline IA 39 & 2 & $\times 10^{17}$ & $\mathrm{~m} \cdot \mathrm{p}$. & 60 & 20 & 80 & 0 & 0 & $82 \pm$ & \pm 4 & -1 to -3 & 0.52 & 0.29 \\
\hline IA 40 & 2 & $\times 10^{17}$ & $\begin{array}{l}1300- \\
1800\end{array}$ & 60 & 20 & 80 & 0 & 0 & $84 \pm$ & \pm 4 & -1 to -3 & 0.42 & 0.28 \\
\hline I B 41 & 2 & $\times 10^{17}$ & $\mathrm{~m} \cdot \mathrm{p}$ & 60 & 20 & 80 & 0 & 0 & $84 \pm$ & \pm 8 & 0 to -2 & 0.035 & 0.035 \\
\hline IB 42 & 2 & $\times 10^{17}$ & $\mathrm{~m} \cdot \mathrm{p}$ & 60 & 0 & 90 & 1 & 9 & $84 \pm$ & \pm 8 & 0 to -3 & 0.058 & 0.058 \\
\hline
\end{tabular}

(a) All series I tests made in Painted Aerosol Tank (PAT) with equimolar steam-air atmosphere. No mechanical agitation.

(b) m.p. means UO 2 was melted.

(c) Trouble with inzeaking air. 
TABLE 2. Series S Experimental Conditions ${ }^{(\alpha)}$ (Simulant Sources)

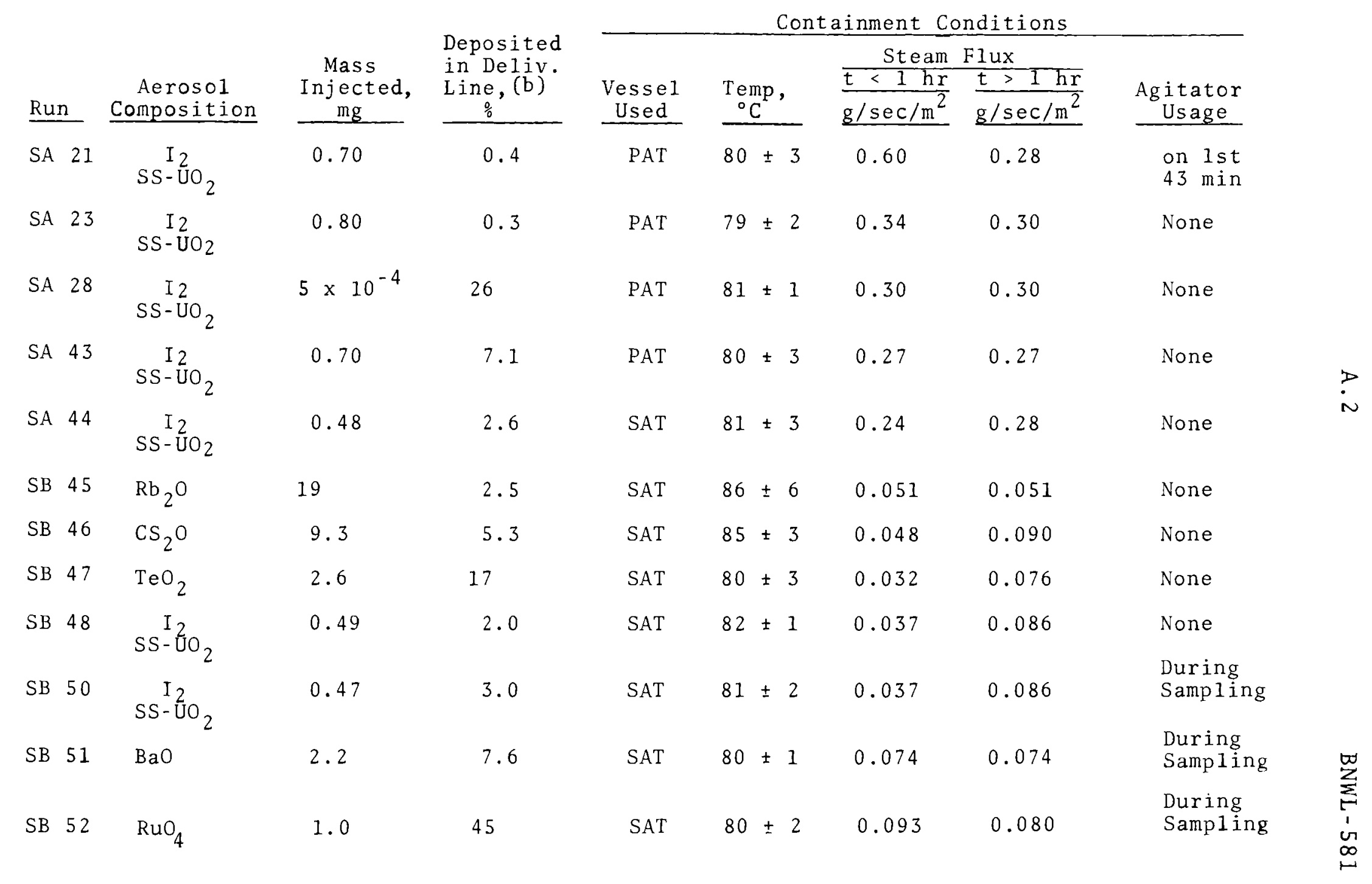


TABLE 2. (Contd)

\begin{tabular}{|c|c|c|c|c|c|c|c|c|c|}
\hline \multirow{2}{*}{\multicolumn{2}{|c|}{ Run }} & \multirow[b]{2}{*}{$\begin{array}{c}\text { Aerosol } \\
\text { Composition } \\
\end{array}$} & \multirow[b]{2}{*}{$\begin{array}{c}\text { Mass } \\
\text { Injected, } \\
\mathrm{mg}\end{array}$} & \multirow[b]{2}{*}{$\begin{array}{l}\text { Deposited } \\
\text { in Deliv. } \\
\text { Line, (b) } \\
\frac{o}{0} \\
\end{array}$} & \multicolumn{4}{|c|}{ Containment Conditions } & \multirow[b]{2}{*}{$\begin{array}{c}\text { Agitator } \\
\text { Usage } \\
\end{array}$} \\
\hline & & & & & $\begin{array}{l}\text { Vesse1 } \\
\text { Used } \\
\end{array}$ & $\begin{array}{l}\text { Temp } \\
{ }^{\circ} \mathrm{C}\end{array}$ & $\frac{\text { Steam }}{\mathrm{t}<\mathrm{g} / \mathrm{hr}}$ & $\begin{array}{l}\text { F1ux } \\
\frac{\mathrm{t}>1 \mathrm{hr}}{\mathrm{g} / \mathrm{sec} / \mathrm{m}^{2}}\end{array}$ & \\
\hline SB & 53 & $\mathrm{I}_{2}$ & 0.91 & 3.3 & SAT & $80 \pm 2$ & 0.067 & 0.090 & During \\
\hline & & $\mathrm{CS}_{2} \mathrm{O}$ & 0.53 & 11 & & & & & Sampling \\
\hline & & $\mathrm{RuO}_{4}$ & 1.2 & 15 & & & & & \\
\hline & & $\mathrm{TeO}_{2}$ & 0.73 & 3.0 & & & & & \\
\hline & & $\begin{array}{l}\mathrm{BaO} \\
\mathrm{SS}-\mathrm{UO}_{2}\end{array}$ & 0.70 & 5.0 & & & & & \\
\hline SB & 60 & $\begin{array}{c}\mathrm{I}_{2} \\
\mathrm{SS}-\mathrm{UO}_{2}\end{array}$ & 0.70 & 12 & SAT & $80 \pm 1$ & 0.031 & 0.067 & $\begin{array}{l}\text { Steam Jet } \\
\text { Injector }\end{array}$ \\
\hline SB & 61 & $\begin{array}{c}\mathrm{I}_{2} \\
\mathrm{SS}-\mathrm{UO}_{2}\end{array}$ & 1.35 & 21 & SAT & $82 \pm 2$ & 0.042 & 0.055 & Intermittent \\
\hline SB & 63 & $\begin{array}{c}\mathrm{I}_{2} \\
\mathrm{SS}-\mathrm{UO}_{2}\end{array}$ & 95 & 0.1 & SAT & $81 \pm 2$ & 0.042 & 0.042 & on entire run \\
\hline SB & 64 & $\begin{array}{c}\mathrm{I}_{2} \\
\mathrm{Zr}-\mathrm{UO}_{2}\end{array}$ & 0.97 & 1.3 & SAT & $82 \pm 2$ & 0.053 & 0.053 & on entire run \\
\hline SB & 74 & $\mathrm{I}_{2}$ & 46.8 & 0.9 & SAT & $81 \pm 2$ & 0.045 & 0.045 & $\begin{array}{l}\text { During } \\
\text { Sampling }\end{array}$ \\
\hline SB & 78 & $\mathrm{Cs}_{2} \mathrm{I}_{2} \mathrm{O}$ & $\begin{array}{l}0.87 \\
2.4\end{array}$ & 12.3 & SAT & $80 \pm 3$ & 0.045 & 0.065 & $\begin{array}{l}\text { During } \\
\text { Sampling }\end{array}$ \\
\hline
\end{tabular}

(a) AIZ Series $S$ Tests were with equimolar steam-air containment atmosphere at -1 in. Hg gage pressure.

(b) Percent of mass entering the delivery zine. 
TABLE 3. Fission Product Release from Irradiated Specimens

\begin{tabular}{|c|c|c|c|c|c|}
\hline E1ement & Run & $\begin{array}{c}\text { Release } \\
\text { from } \mathrm{UO}_{2}, \\
\end{array}$ & \multicolumn{2}{|c|}{$\begin{array}{l}\text { Delivered to } \\
\text { Containment }\end{array}$} & $\begin{array}{l}\text { Deposited in }(\mathrm{d}) \\
\text { Delivery Line, } \\
\frac{0}{0}\end{array}$ \\
\hline Iodine & $\begin{array}{ll}\text { IA } & 26 \\
\text { IA } & 32 \\
\text { IA } & 33 \\
\text { IA } & 39 \\
\text { IA } & 40 \\
\text { IB } & 41 \\
\text { IB } & 42\end{array}$ & $\begin{array}{l}82 \\
82^{(e)} \\
81 \\
99 \\
75 \\
99 \\
96\end{array}$ & $\begin{array}{l}0.07 \\
0.28 \\
0.25 \\
0.45 \\
0.35 \\
0.42 \\
0.42\end{array}$ & $\begin{array}{l}72 \\
68 \\
65 \\
89 \\
67 \\
83 \\
83\end{array}$ & $\begin{array}{c}6 \\
14 \\
20 \\
8 \\
0.2 \\
13 \\
12\end{array}$ \\
\hline Cesium & $\begin{array}{ll}\text { IA } & 32 \\
\text { IA } & 33 \\
\text { IA } & 39 \\
\text { IA } & 40 \\
\text { IB } & 41 \\
\text { IB } & 42\end{array}$ & $\begin{array}{l}65 \\
64 \\
99 \\
30 \\
93 \\
94\end{array}$ & $\begin{array}{l}1.8 \\
1.6 \\
4.7 \\
1.0 \\
4.3 \\
4.5\end{array}$ & $\begin{array}{l}58 \\
55 \\
78 \\
18 \\
74 \\
74\end{array}$ & $\begin{array}{l}11 \\
15 \\
12 \\
30 \\
12 \\
10\end{array}$ \\
\hline Tellurium & $\begin{array}{ll}\text { IA } & 32 \\
\text { IA } & 33 \\
\text { IB } & 41 \\
\text { IB } & 42\end{array}$ & $\begin{array}{l}51 \\
50 \\
94 \\
96\end{array}$ & $\begin{array}{l}0.2 \\
0.2 \\
0.7 \\
0.8\end{array}$ & $\begin{array}{l}47 \\
41 \\
75 \\
83\end{array}$ & $\begin{array}{r}7 \\
16 \\
13 \\
11\end{array}$ \\
\hline Ruthenium & $\begin{array}{ll}\text { IA } & 39 \\
\text { IA } & 40 \\
\text { I B } & 41 \\
\text { IB } & 42\end{array}$ & $\begin{array}{l}14 \\
21 \\
53 \\
18\end{array}$ & $\begin{array}{l}0.2 \\
0.5 \\
1.5 \\
0.6\end{array}$ & $\begin{array}{r}6 \\
12 \\
38 \\
15\end{array}$ & $\begin{array}{l}55 \\
38 \\
27 \\
13\end{array}$ \\
\hline Barium & $\begin{array}{ll}\text { IA } & 39 \\
\text { IA } & 40 \\
\text { I B } & 41 \\
\text { IB } & 42\end{array}$ & $\begin{array}{l}0.22 \\
0.13 \\
0.07 \\
0.10\end{array}$ & $\begin{array}{l}0.06 \\
0.03 \\
0.02 \\
0.02\end{array}$ & $\begin{array}{l}0.18 \\
0.07 \\
0.05 \\
0.06\end{array}$ & $\begin{array}{l}12 \\
39 \\
29 \\
25\end{array}$ \\
\hline
\end{tabular}

\footnotetext{
(a) Escaped from fuel-clad $\mathrm{UO}_{2}$ and granular bed, \% of inventory.

(b) Estimated from irradiation history.

(c) Percent of inventory.

(d) Percent of material entering delivery line.

(e) Insufficient analyses.
} 
TABLE 4. Iodine Form as Sampled from Delivery Line ${ }^{(a)}$

Run

$\underline{\text { Irradiated }}$

IA 26

IA 33

IA 39

IA 40 ( $f$ )

I B 41

IB 42

Average

(Std. Dev.)

Simulant

SA 21

SA 23

SA 28

SA 43

SA 44

SB 48

SB 50

SB 53

SB 60

SB 61

SB 63

SB 64

Average

(Std. Dev.)
Maypack Distribution,

Charcoal Silver
Impregnated
Paperens (c)

Charcoal (e) Bed

\begin{tabular}{l}
66 \\
73 \\
10 \\
81 \\
80 \\
14 \\
\hline 49 \\
$(33)$
\end{tabular}

97

84

40

30

96

14

88

10

95

43

98

$\frac{70}{66}$

(34)

\begin{tabular}{c}
5 \\
9 \\
20 \\
9 \\
3.4 \\
0.3 \\
\hline 8 \\
$(7)$
\end{tabular}

0.2

1.0

0.5

1.0

0.6

$\frac{0.2}{0.58}$

$(0.36)$

.
0
5
0
.58
$36)$


TABLE 5. Effect of Iodine (a) Mass Loading on Maypack Distribution ( $800^{\circ} \mathrm{C}, 1 \mathrm{~atm}$ pressure, equimolar steam-air, $50 \mathrm{ft} / \mathrm{min}$ superficial velocity through Maypack, 3 min sample period)

Iodine mass sampled, mg

$\%$ retained on filter

o retained on silver screens

$\%$ retained on charcoal paper

$\%$ retained on charcoal bed

\begin{tabular}{rc}
5.0 & 0.15 \\
\hline 7.0 & 40.1 \\
92.4 & 58.9 \\
0.5 & 1.0 \\
0.1 & 0.05
\end{tabular}

(a) Elemental Iodine was prepared by $\mathrm{K}_{2} \mathrm{Cr}_{2} \mathrm{O}$ fusion method and released by heating the storage cold trap. 
TABLE 6. Iodine Form in Containment Gas Phase After 10 min Containment Time

\begin{tabular}{|c|c|c|c|c|}
\hline \multirow[b]{2}{*}{$\underline{\text { Run }}$} & \multicolumn{4}{|c|}{ Maypack Distribution: } \\
\hline & Filter & $\begin{array}{l}\text { Silver } \\
\text { Screens }\end{array}$ & $\begin{array}{l}\text { Charcoal } \\
\text { Impreg. } \\
\text { Paper } \\
\end{array}$ & $\begin{array}{c}\text { Charcoa } 1 \\
\text { Bed } \\
\end{array}$ \\
\hline \multicolumn{5}{|l|}{ Irradiated } \\
\hline $\begin{array}{c}\text { IA } 26 \\
\text { IA } 32 \\
\text { IA } 33 \\
\text { IA } 39 \\
\text { IA } 40 \\
\text { IB } 41 \\
\text { IB } 42 \\
\text { Average } \\
\text { (Std. Dev.) }\end{array}$ & $\begin{array}{l}80 \\
73 \\
33 \\
61 \\
73 \\
73 \\
99 \\
70 \\
(20)\end{array}$ & $\begin{array}{c}11 \\
10 \\
35 \\
11 \\
1 \\
10 \\
0.4 \\
11 \\
(11)\end{array}$ & $\begin{array}{r}7 \\
14 \\
29 \\
19 \\
17 \\
10 \\
0.3 \\
14.0 \\
(8.7)\end{array}$ & $\begin{array}{c}1 \\
3 \\
23 \\
9 \\
9 \\
7 \\
0.4 \\
4.6 \\
(3.6)\end{array}$ \\
\hline \multicolumn{5}{|l|}{$\underline{\text { Simulant }}$} \\
\hline $\begin{array}{ll}\text { SA } & 21 \\
\text { SA } & 23 \\
\text { SA } & 28 \\
\text { SA } & 43 \\
\text { SA } & 44 \\
\text { SB } & 48 \\
\text { SB } & 50 \\
\text { SB } & 53 \\
\text { SB } & 60 \\
\text { SB } & 61 \\
\text { SB } & 63 \\
\text { SB } & 64 \\
\text { SB } 74 \\
\text { Average } \\
\text { (Std. Dev.) }\end{array}$ & $\begin{array}{l}34 \\
39 \\
64 \\
52 \\
84 \\
98 \\
98 \\
85 \\
98 \\
99 \\
5 \\
95 \\
15 \\
67 \\
(34)\end{array}$ & $\begin{array}{c}33 \\
58 \\
22 \\
47 \\
15 \\
1 \\
1 \\
15 \\
1 \\
0.2 \\
94 \\
0.4 \\
83 \\
28 \\
(32)\end{array}$ & $\begin{array}{l}19 \\
2 \\
4 \\
0.3 \\
1 \\
1 \\
0.4 \\
0.5 \\
0.6 \\
1 \\
1 \\
4 \\
1.6 \\
2.8 \\
(5.0)\end{array}$ & $\begin{array}{c}14 \\
0.6 \\
10 \\
0.3 \\
0.1 \\
0.2 \\
0.1 \\
0.06 \\
0.1 \\
0.1 \\
0.1 \\
0.6 \\
0.9 \\
2.1 \\
(4.5)\end{array}$ \\
\hline
\end{tabular}


TABLE 7. Iodine Form in Containment Gas Phase After $5 \mathrm{hr}$ Containment Time

$\underline{\text { Run }}$

Irradiated

IA 26

IA 32

IA 33

IA 39

IA 40

I B 41

IB 42

Avg. Irrad.

(Std. Dev.)

Simulants

SA 21

SA 23

SA 28

SA 43

SA 44

SB 48

$\mathrm{SB} 50$

$\mathrm{SB} 53$

SB 60

$\mathrm{SB} 61$

SB 63

SB 64

SB 74

Avg. Sim.

(Std. Dev.)
Maypack Distribution:

\begin{tabular}{llcl}
\multicolumn{3}{c}{ Maypack } & Distribution $\%$ \\
\hline Filter & $\begin{array}{l}\text { Silver } \\
\text { Screens }\end{array}$ & $\begin{array}{c}\text { Impreg. } \\
\text { Paper }\end{array}$ & $\begin{array}{c}\text { Charcoal } \\
\text { Bed }\end{array}$ \\
\hline
\end{tabular}

\section{4}

0.9

1

0.5

0.4

0.5

0.2

$\frac{1}{0.9}$

(0.9)

$\frac{0.9}{1.2}$

$(1.3)$

\begin{tabular}{l}
0.03 \\
1.0 \\
0.2 \\
0.2 \\
1.4 \\
28 \\
3 \\
0.6 \\
3 \\
0.1 \\
13 \\
2 \\
2 \\
\hline 4.2 \\
$(7.9)$
\end{tabular}

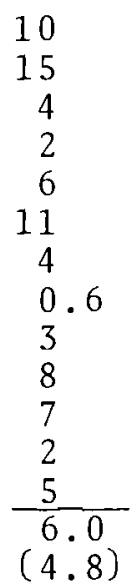

\begin{tabular}{r}
37 \\
7 \\
27 \\
48 \\
27 \\
30 \\
25 \\
\hline 29 \\
$(12)$
\end{tabular}

58

92

71

49

70

70

$\frac{73}{69}$

(14) 
TABLE 8. Effect of Mass ReZeased on Iodine Form

\section{Conditions of \\ Samp1ing \\ Delivery Line \\ During Injection}

Irradiated, Avg.

Simulant, Run 28

Simulant, Avg.

Simulant, Run 63

Containment After

\section{$10 \mathrm{~min}$}

Irradiated, Avg.

Simulant, Run 28

Simulant, Avg

Simulant, Run 63

\section{Containment After} $300 \mathrm{~min}$

Irradiated, Avg

Simulant, Run 28

Simulant, Avg

Simulant, Run 63

\section{Iodine}

Mass

Released,

$\mu \mathrm{g}$

$$
\begin{array}{r}
\sim 0.5 \\
0.5 \\
10 \dot{3}^{5}
\end{array}
$$

$10^{5}$

$$
\begin{array}{r}
\sim 0.5 \\
0.5 \\
\sim 10 \dot{3}^{5} \\
10^{5}
\end{array}
$$

\begin{tabular}{|c|c|c|c|}
\hline Filter & $\begin{array}{r}\text { Silver } \\
\text { Screens }\end{array}$ & $\begin{array}{c}\text { Charcoal } \\
\text { Paper }\end{array}$ & $\begin{array}{c}\text { Charcoal } \\
\text { Bed }\end{array}$ \\
\hline $\begin{array}{r}43 \pm 30 \\
54 \\
32 \pm 33 \\
0.7\end{array}$ & $\begin{array}{l}49 \pm 33 \\
40 \\
66 \pm 34 \\
98\end{array}$ & $\begin{array}{l}8 \pm 7 \\
6 \\
1.6 \pm 1.7 \\
0.4\end{array}$ & $\begin{array}{l}0.58 \pm 0.36 \\
0.7 \\
0.14 \pm 0.22 \\
0.01\end{array}$ \\
\hline
\end{tabular}

$$
\begin{array}{r}
\sim 0.5 \\
0.5 \\
103^{5}
\end{array}
$$$$
10^{5}
$$

Percent Retained on Maypack Component

$70 \pm 20$
64
$67 \pm 34$
5

$11 \pm 11$
22
$28 \pm 32$
94
$14 \pm 9$
$2.8 \pm 5.0$

$4.6 \pm 3.6$

10

$2.1 \pm 4.5$

0.1 
TABLE 9. Gas Phase Mass Transfer Coefficients--Total Iodine

\begin{tabular}{|c|c|c|c|c|c|c|}
\hline Run & $\begin{array}{l}\text { Steam Flux } \\
\times 10^{6}, \dot{c m}^{2} \\
\mathrm{~g} / \mathrm{sec}-\mathrm{cm}^{2}\end{array}$ & $\begin{array}{c}\mathrm{Ha} 1 \mathrm{f} \\
\mathrm{Life}, \\
\mathrm{min}\end{array}$ & $\frac{\mathrm{K}_{\mathrm{G}}, \mathrm{cm}}{\text { Measured }}$ & $\mathrm{Eq}(33)$ & $\underline{K}_{\mathrm{K}}$ Me as ured & \\
\hline \multicolumn{7}{|l|}{ Irradiated } \\
\hline $\begin{array}{ll}\text { IA } & 26 \\
\text { IA } & 32 \\
\text { IA } & 33 \\
\text { IA } & 39\end{array}$ & $\begin{array}{l}18 \\
45 \\
40 \\
52 \\
\end{array}$ & $\begin{array}{l}10 \\
5 \\
4.5 \\
4 \\
\end{array}$ & $\begin{array}{l}0.022 \\
0.045 \\
0.049 \\
0.056 \\
\end{array}$ & $\begin{array}{l}0.033 \\
0.058 \\
0.054 \\
0.063 \\
\end{array}$ & $\begin{array}{l}0.67 \\
0.78 \\
0.91 \\
0.89 \\
\end{array}$ & \\
\hline $\begin{array}{l}\text { Series IA Avg } \\
\text { (Std. Dev.) }\end{array}$ & $\begin{array}{c}39 \\
(13)\end{array}$ & & $\begin{array}{c}0.043 \\
(0.015)\end{array}$ & 0.052 & 0.83 & \\
\hline $\begin{array}{ll}\text { IB } & 41 \\
\text { IB } & 42\end{array}$ & $\begin{array}{l}3.5 \\
5.8 \\
\end{array}$ & $\begin{array}{l}16 \\
13 \\
\end{array}$ & $\begin{array}{l}0.014 \\
0.017 \\
\end{array}$ & $\begin{array}{l}0.012 \\
0.017 \\
\end{array}$ & $\begin{array}{l}1.2 \\
1.0 \\
\end{array}$ & \\
\hline $\begin{array}{l}\text { Series IB Avg } \\
\text { (Std. Dev.) }\end{array}$ & $\begin{array}{r}4.65 \\
(1.6)\end{array}$ & & $\begin{array}{c}0.0155 \\
(0.0021)\end{array}$ & 0.0145 & 1.1 & \\
\hline \multicolumn{7}{|l|}{ Simulant } \\
\hline $\begin{array}{ll}\text { SA } & 21 \\
\text { SA } & 23 \\
\text { SA } & 28 \\
\text { SA } & 43 \\
\text { SA } & 44\end{array}$ & $\begin{array}{l}52 \\
34 \\
30 \\
27 \\
24 \\
\end{array}$ & $\begin{array}{l}3.1 \\
4.5 \\
5 \\
4 \\
4.5 \\
\end{array}$ & $\begin{array}{l}0.071 \\
0.049 \\
0.045 \\
0.056 \\
0.045 \\
\end{array}$ & $\begin{array}{l}0.063 \\
0.049 \\
0.045 \\
0.042 \\
0.039 \\
\end{array}$ & $\begin{array}{l}1.12 \\
1.00 \\
1.00 \\
1.33 \\
1.15 \\
\end{array}$ & 0 \\
\hline 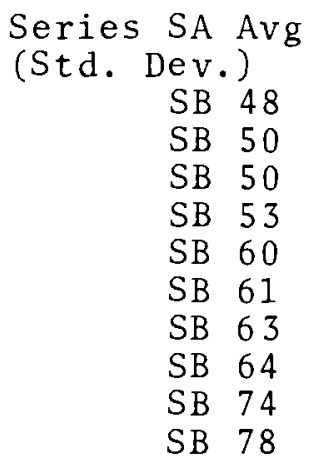 & $\begin{array}{r}33.4 \\
(11)^{-} \\
3.7 \\
3.7 \\
8.6 \\
6.7 \\
3.1 \\
4.2 \\
4.2 \\
5.3 \\
4.5 \\
6.5 \\
\end{array}$ & $\begin{array}{r}22 \\
17 \\
11 \\
7.5 \\
10.5 \\
14 \\
5.5 \\
15 \\
6.5 \\
9.0 \\
\end{array}$ & $\begin{array}{l}0.053 \\
(0.011) \\
0.009 \\
0.012 \\
0.018 \\
0.027 \\
0.019 \\
0.014 \\
0.037 \\
0.013 \\
0.031 \\
0.022 \\
\end{array}$ & $\begin{array}{l}0.0476 \\
0.0125 \\
0.0125 \\
0.021 \\
0.018 \\
0.011 \\
0.0135 \\
0.0135 \\
0.016 \\
0.0145 \\
0.018\end{array}$ & $\begin{array}{l}1.12 \\
0.72 \\
0.96 \\
0.86 \\
1.50 \\
1.73 \\
1.04 \\
2.74 \\
0.81 \\
2.20 \\
1.22 \\
\end{array}$ & $\sum_{1}^{\infty}$ \\
\hline $\begin{array}{l}\text { Series SB Avg } \\
\text { (Std. Dev.) }\end{array}$ & $\begin{array}{r}5.05 \\
(1.8)\end{array}$ & & $\begin{array}{c}0.0202 \\
(0.0092)\end{array}$ & 0.0151 & 1.38 & $\stackrel{\cup}{\bullet}$ \\
\hline
\end{tabular}


TABLE 10. Gas Phase Mass Transfer Coefficients--Particulate Iodine

\begin{tabular}{|c|c|c|c|c|c|c|}
\hline Run & $\begin{array}{l}\text { Steam Flux } \\
\times 10^{6},{ }^{2} \\
\text { g/sec-cm }\end{array}$ & $\begin{array}{l}\text { Half } \\
\text { Life, } \\
\text { min } \\
\end{array}$ & $\frac{\mathrm{K}_{\mathrm{G}}, \mathrm{c}}{\underline{\text { Measured }}}$ & Eq $(\overline{33})$ & $\underline{\mathrm{K}}_{\mathrm{K}} \frac{\text { Measured }}{\mathrm{Eq}(33)}$ & \\
\hline \multicolumn{7}{|l|}{ Irradiated } \\
\hline $\begin{array}{ll}\text { IA } & 26 \\
\text { IA } & 32 \\
\text { IA } & 33 \\
\text { IA } & 39 \\
\text { IA } & 40\end{array}$ & $\begin{array}{l}18 \\
45 \\
40 \\
52 \\
28 \\
\end{array}$ & $\begin{array}{l}10 \\
4.2 \\
4.2 \\
5 \\
4.5 \\
\end{array}$ & $\begin{array}{l}0.022 \\
0.053 \\
0.053 \\
0.045 \\
0.049 \\
\end{array}$ & $\begin{array}{l}0.033 \\
0.058 \\
0.054 \\
0.063 \\
0.043 \\
\end{array}$ & $\begin{array}{l}0.67 \\
0.92 \\
0.98 \\
0.72 \\
1.14 \\
\end{array}$ & \\
\hline $\begin{array}{l}\text { Series IA Avg } \\
\text { (Std. Dev.) }\end{array}$ & $\begin{array}{r}36.6 \\
( \pm 13)^{6}\end{array}$ & & $\begin{array}{c}0.0444 \\
(0.0128)\end{array}$ & 0.050 & 0.89 & \\
\hline $\begin{array}{ll}\text { I B } & 41 \\
\text { I B } & 42\end{array}$ & $\begin{array}{l}3.5 \\
5.8 \\
\end{array}$ & $\begin{array}{l}16 \\
13 \\
\end{array}$ & $\begin{array}{l}0.014 \\
0.017 \\
\end{array}$ & $\begin{array}{l}0.012 \\
0.017 \\
\end{array}$ & $\begin{array}{l}1.16 \\
1.00 \\
\end{array}$ & \\
\hline $\begin{array}{l}\text { Series IB Avg } \\
\text { (Std. Dev.) }\end{array}$ & $\begin{array}{r}4.65 \\
\pm \quad 1.6)\end{array}$ & & $\begin{array}{c}0.0155 \\
(0.0021)\end{array}$ & 0.0145 & 1.08 & \\
\hline \multicolumn{7}{|l|}{ Simulant } \\
\hline $\begin{array}{ll}\text { SA } & 21 \\
\text { SA } & 23 \\
\text { SA } & 28 \\
\text { SA } & 43 \\
\text { SA } & 44\end{array}$ & $\begin{array}{l}52 \\
34 \\
30 \\
27 \\
24 \\
\end{array}$ & $\begin{array}{l}4.2 \\
4.5 \\
5 \\
4 \\
4.2 \\
\end{array}$ & $\begin{array}{l}0.053 \\
0.049 \\
0.045 \\
0.055 \\
0.047 \\
\end{array}$ & $\begin{array}{l}0.063 \\
0.049 \\
0.045 \\
0.042 \\
0.039 \\
\end{array}$ & $\begin{array}{l}0.85 \\
1.00 \\
1.00 \\
1.31 \\
1.20 \\
\end{array}$ & • \\
\hline $\begin{array}{l}\text { Series SA Avg } \\
\text { (Std. Dev.) }\end{array}$ & $\begin{array}{l}33.4 \\
(11)^{4}\end{array}$ & & $\begin{array}{c}0.0498 \\
(0.0040)\end{array}$ & 0.0476 & 1.04 & \\
\hline $\begin{array}{cc}\text { SB } & 48 \\
\text { SB } & 50 \\
\text { SB } & 50 \\
\text { SB } & 53 \\
\text { SB } & 60 \\
\text { SB } & 61 \\
\text { SB } & 63 \\
\text { SB } & 64 \\
\text { SB } & 74 \\
\text { SB } & 78\end{array}$ & $\begin{array}{l}3.7 \\
3.7 \\
8.6 \\
6.7 \\
3.1 \\
4.2 \\
4.2 \\
5.3 \\
4.5 \\
6.5 \\
\end{array}$ & $\begin{array}{r}22 \\
17 \\
10 \\
7.3 \\
10.3 \\
14 \\
21 \\
14.5 \\
9.5 \\
8.5 \\
\end{array}$ & $\begin{array}{l}0.009 \\
0.012 \\
0.022 \\
0.027 \\
0.019 \\
0.014 \\
0.009 \\
0.014 \\
0.021 \\
0.023 \\
\end{array}$ & $\begin{array}{l}0.0125 \\
0.0125 \\
0.021 \\
0.018 \\
0.011 \\
0.0135 \\
0.0135 \\
0.016 \\
0.0145 \\
0.018 \\
\end{array}$ & $\begin{array}{l}0.72 \\
0.96 \\
1.04 \\
1.50 \\
1.72 \\
1.04 \\
0.67 \\
0.88 \\
1.45 \\
1.28\end{array}$ & $\sum^{\infty}$ \\
\hline $\begin{array}{l}\text { Series SB Avg } \\
\text { (Std. Dev.) }\end{array}$ & $\begin{array}{r}5.05 \\
( \pm 1.8)\end{array}$ & & $\begin{array}{c}0.0170 \\
(0.0062)\end{array}$ & 0.0151 & 1.13 & $\underset{\infty}{\infty}$ \\
\hline
\end{tabular}


TABLE 11. Gas Phase Mass Transfer Coefficients--EZemental Iodine

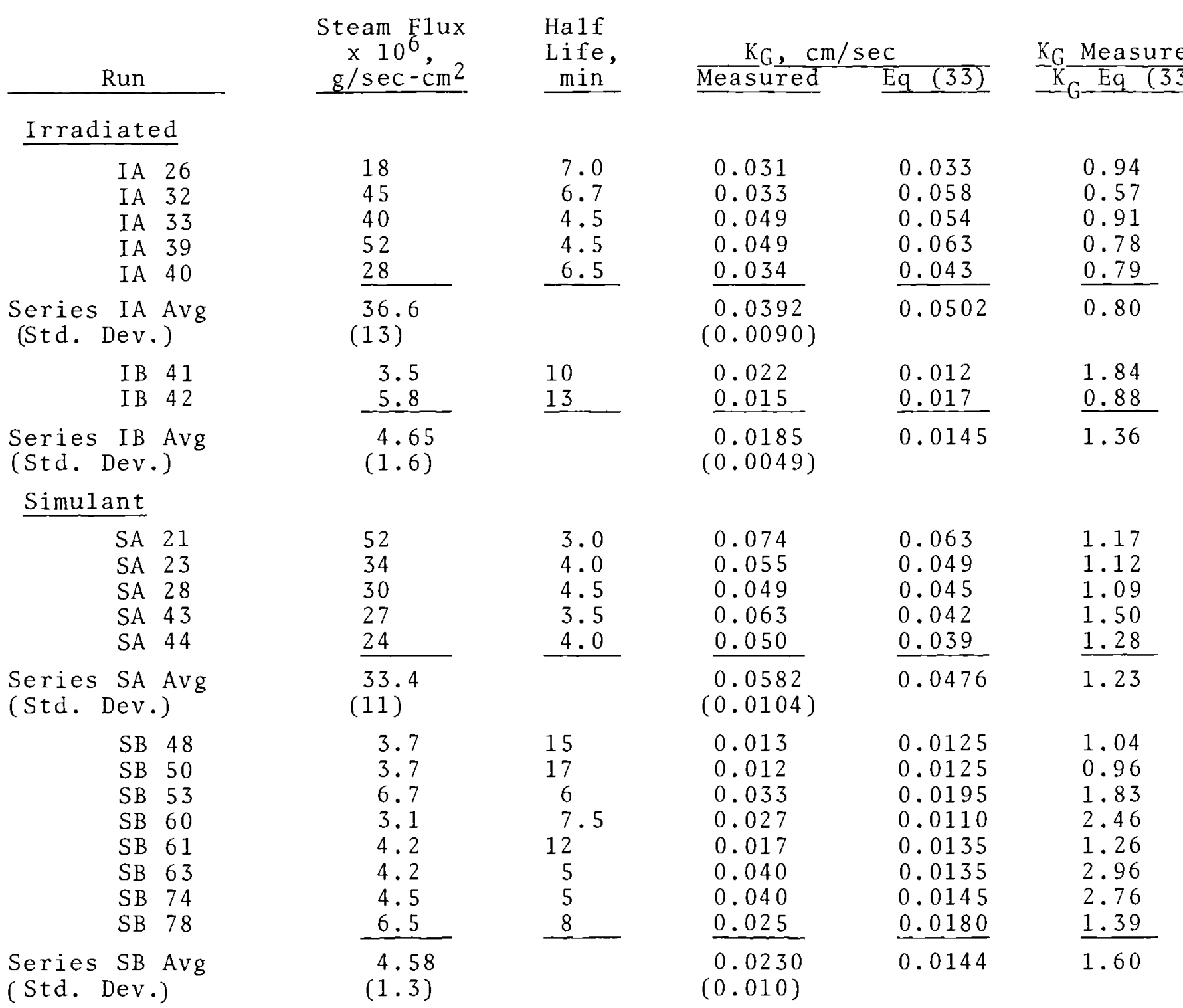


TABLE 12. Gas Phase Mass Transport Coefficients--Cesium

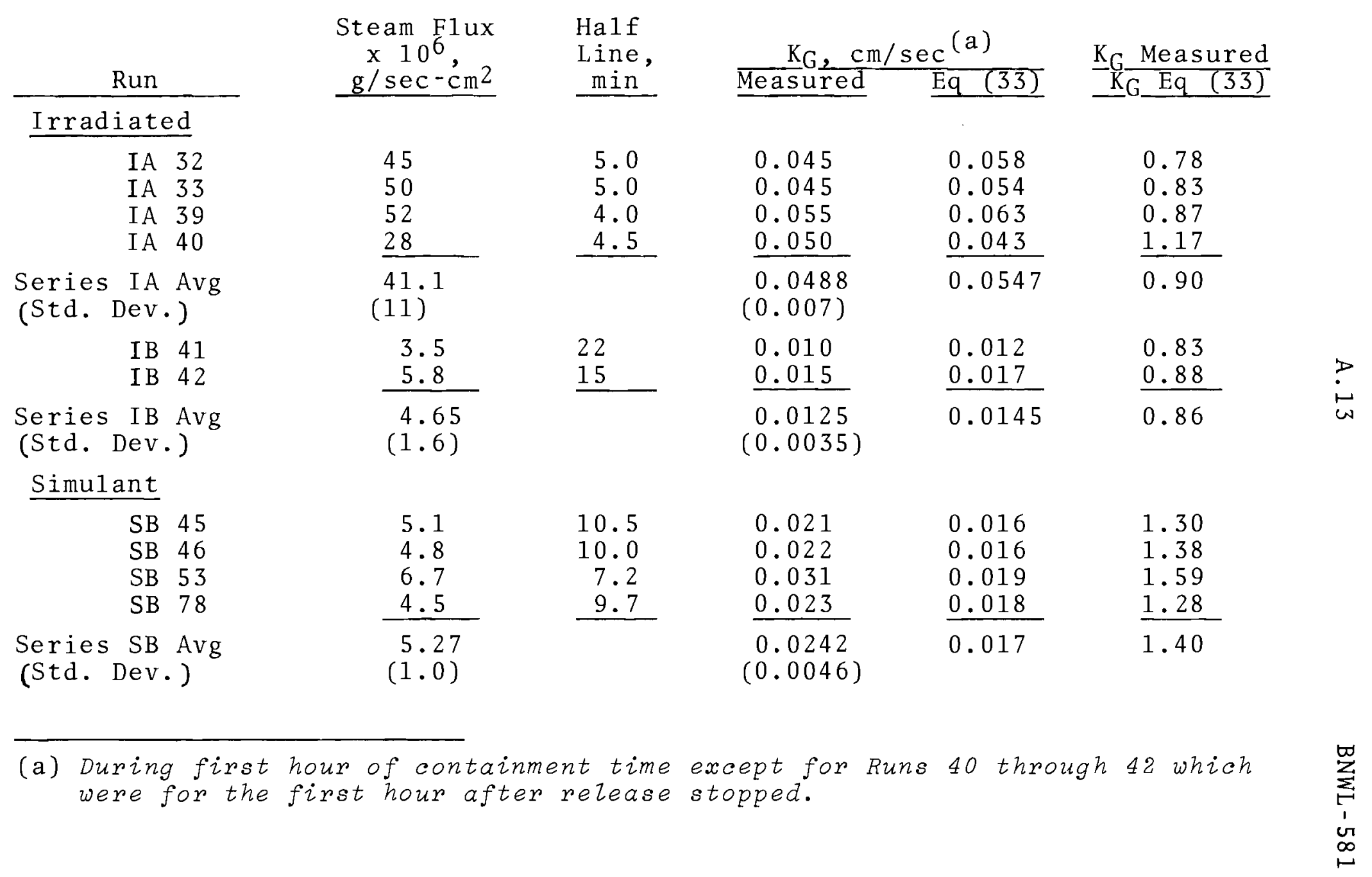


TABLE 13. Gas Phase Mass Transport Coefficients--TeZZurium

\begin{tabular}{|c|c|c|c|c|c|c|}
\hline Run & $\begin{array}{l}\text { Steam F1ux } \\
x 10^{6}, \\
\mathrm{~g} / \mathrm{sec}-\mathrm{cm}^{2} \\
\end{array}$ & $\begin{array}{l}\text { Half } \\
\text { Line, } \\
\text { min }\end{array}$ & $\frac{\mathrm{K}_{\mathrm{G}} \text {, } \mathrm{c}}{\text { Measured }}$ & $\mathrm{Eq}(33)$ & $\frac{K_{G} \text { Measured }}{K_{G} \text { Eq (33) }}$ & \\
\hline \multicolumn{7}{|l|}{ Irradiated } \\
\hline $\begin{array}{ll}\text { IA } & 32(\mathrm{a}) \\
\text { IA } & 33\end{array}$ & $\begin{array}{l}45 \\
40 \\
\end{array}$ & $\begin{array}{l}4 \\
5 \\
\end{array}$ & $\begin{array}{l}0.055 \\
0.045 \\
\end{array}$ & $\begin{array}{l}0.058 \\
0.054 \\
\end{array}$ & $\begin{array}{l}0.95 \\
0.83 \\
\end{array}$ & \\
\hline $\begin{array}{l}\text { Series IA Avg } \\
\text { (Std. Dev.) }\end{array}$ & $\begin{array}{l}42.5 \\
(3.5)\end{array}$ & & $\begin{array}{c}0.050 \\
(0.007)\end{array}$ & 0.056 & 0.90 & \\
\hline $\begin{array}{l}\text { IB } 41 \text { (b) } \\
\text { IB } 42 \text { (b) }\end{array}$ & $\begin{array}{l}3.5 \\
5.8 \\
\end{array}$ & $\begin{array}{l}25 \\
14 \\
\end{array}$ & $\begin{array}{l}0.009 \\
0.016 \\
\end{array}$ & $\begin{array}{l}0.012 \\
0.017 \\
\end{array}$ & $\begin{array}{l}0.75 \\
0.94 \\
\end{array}$ & $?$ \\
\hline $\begin{array}{l}\text { Series IB Avg } \\
\text { (Std. Dev.) }\end{array}$ & $\begin{array}{r}4.65 \\
(1.6)\end{array}$ & & $\begin{array}{c}0.0125 \\
(0.0049)\end{array}$ & 0.0145 & 0.84 & $\stackrel{\bullet}{+}$ \\
\hline \multicolumn{7}{|l|}{ Simulated } \\
\hline 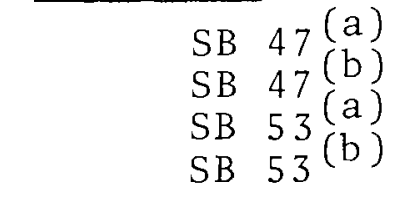 & $\begin{array}{l}3.2 \\
7.6 \\
6.7 \\
9.1 \\
\end{array}$ & $\begin{array}{r}20 \\
10.5 \\
5.5 \\
9 \\
\end{array}$ & $\begin{array}{l}0.010 \\
0.021 \\
0.040 \\
0.022 \\
\end{array}$ & $\begin{array}{l}0.012 \\
0.020 \\
0.019 \\
0.022 \\
\end{array}$ & $\begin{array}{l}0.83 \\
1.05 \\
2.10 \\
1.00 \\
\end{array}$ & \\
\hline $\begin{array}{l}\text { Series SB Avg } \\
(\text { Std. Dev.) }\end{array}$ & $\begin{array}{c}6.7 \\
(2.5)\end{array}$ & & $\begin{array}{c}0.023 \\
(0.012)\end{array}$ & 0.0182 & 1.24 & \\
\hline
\end{tabular}

(a) During first hour of containment

(b) During second hour of containment 
TABLE 14. Gas Phase Mass Transport Coefficients--Ruthenium

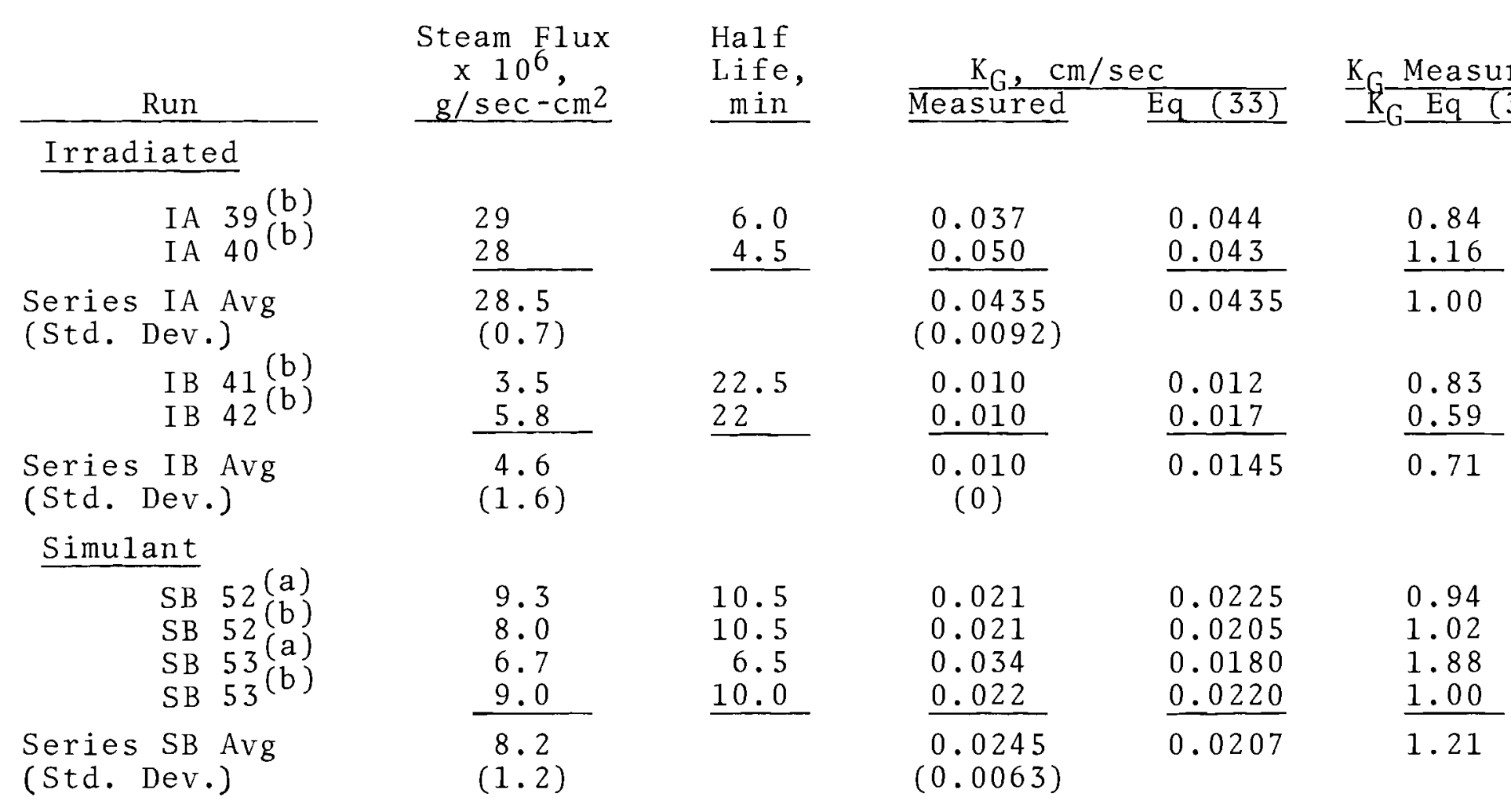

(a) During first hour
(b) During second hour 
TABLE 15. Mass Transfer Coefficients-Barium

\begin{tabular}{|c|c|c|c|c|c|}
\hline & $\begin{array}{c}\text { Steam F1ux } \\
\times 10^{6},\end{array}$ & $\begin{array}{l}\text { Half } \\
\text { Life, }\end{array}$ & $\mathrm{K}_{\mathrm{G}}, \mathrm{c}$ & & $\mathrm{K}_{\mathrm{G}}$ Me asu \\
\hline Run & $\mathrm{g} / \mathrm{sec}-\mathrm{cm}^{2}$ & min & Measured & $\mathrm{Eq}(33)$ & $\mathrm{K} \quad \mathrm{Eq}($ \\
\hline Irradiated & & & & & \\
\hline $\begin{array}{l}\text { IA } 39(\mathrm{~b}) \\
\text { IA } 40\end{array}$ & $\begin{array}{l}29 \\
28\end{array}$ & $\begin{array}{l}5.5 \\
4.5 \\
\end{array}$ & $\begin{array}{l}0.040 \\
0.050\end{array}$ & $\begin{array}{l}0.044 \\
0.043 \\
\end{array}$ & $\begin{array}{l}0.91 \\
1.16 \\
\end{array}$ \\
\hline $\begin{array}{l}\text { Series IA Avg } \\
\text { (Std. Dev.) }\end{array}$ & $\begin{array}{l}28.5 \\
(0.7)\end{array}$ & & $\begin{array}{c}0.045 \\
(0.007)\end{array}$ & 0.0435 & 1.04 \\
\hline $\begin{array}{l}\text { IB } 41(\mathrm{~b}) \\
\text { IB } 42(\mathrm{~b})\end{array}$ & $\begin{array}{l}3.5 \\
5.8 \\
\end{array}$ & $\begin{array}{l}22 \\
20 \\
\end{array}$ & $\begin{array}{l}0.010 \\
0.011 \\
\end{array}$ & $\begin{array}{l}0.012 \\
0.017\end{array}$ & $\begin{array}{l}0.83 \\
0.65\end{array}$ \\
\hline $\begin{array}{l}\text { Series IB Avg } \\
\text { (Std. Dev.) }\end{array}$ & $\begin{array}{r}4.65 \\
(1.6)\end{array}$ & & $\begin{array}{l}0.011 \\
(0.0007)\end{array}$ & 0.0145 & 0.74 \\
\hline Simulant & & & & & \\
\hline $\begin{array}{l}\text { SB } 51 \text { (a) } \\
\text { SB } 51 \text { (b) } \\
\text { SB } 53(\mathrm{a}) \\
\text { SB } 53(\mathrm{~b})\end{array}$ & $\begin{array}{l}7.4 \\
7.4 \\
7.0 \\
9.0 \\
\end{array}$ & $\begin{array}{r}7.5 \\
10.5 \\
9.5 \\
9.5 \\
\end{array}$ & $\begin{array}{l}0.027 \\
0.019 \\
0.021 \\
0.021 \\
\end{array}$ & $\begin{array}{l}0.0195 \\
0.0195 \\
0.0190 \\
0.022 \\
\end{array}$ & $\begin{array}{l}1.38 \\
0.98 \\
1.10 \\
0.96 \\
\end{array}$ \\
\hline $\begin{array}{l}\text { Series SB Avg } \\
\text { (Std. Dev.) }\end{array}$ & $\begin{array}{c}7.7 \\
(0.9)\end{array}$ & & $\begin{array}{c}0.022 \\
(0.0035)\end{array}$ & 0.020 & 1.10 \\
\hline
\end{tabular}

(a) During first hour

(b) During second hour 
TABLE 16. Gas Phase Mass Transfer Coefficients--Uranium

\begin{tabular}{|c|c|c|c|c|c|c|}
\hline Run & $\begin{array}{l}\text { Steam F1ux } \\
\times 10^{6}, \\
\mathrm{~g} / \mathrm{sec}-\mathrm{cm}^{2} \\
\end{array}$ & $\begin{array}{l}\text { Half } \\
\text { Life, } \\
\text { min }\end{array}$ & $\frac{\mathrm{K}_{\mathrm{G}}}{\text { Measured }}$ & $\mathrm{Eq}(33)$ & $\underline{K}_{\mathrm{K}_{\mathrm{K}}} \frac{\text { Me a sured }}{\mathrm{Eq}(33)}$ & \\
\hline \multicolumn{7}{|l|}{ Irradiated } \\
\hline $\begin{array}{ll}\text { IA } & 32(\mathrm{a}) \\
\text { IA } & 33\end{array}$ & $\begin{array}{l}45 \\
40 \\
\end{array}$ & $\begin{array}{l}6.5 \\
6.0 \\
\end{array}$ & $\begin{array}{l}0.034 \\
0.037 \\
\end{array}$ & $\begin{array}{l}0.058 \\
0.054 \\
\end{array}$ & $\begin{array}{l}0.59 \\
0.69 \\
\end{array}$ & \\
\hline $\begin{array}{l}\text { Series IA Avg } \\
\text { (Std. Dev.) }\end{array}$ & $\begin{array}{l}42.5 \\
(3.5)\end{array}$ & & $\begin{array}{c}0.0355 \\
(0.0021)\end{array}$ & 0.056 & 0.64 & \\
\hline \multicolumn{7}{|l|}{$\underline{\text { Simulant }}$} \\
\hline $\begin{array}{ll}\text { SB } & 61(\mathrm{a}) \\
\text { SB } & 61 \\
\text { SB } & (\mathrm{a}) \\
\text { SB } & 78(\mathrm{~b}) \\
\text { SB } & 78(\mathrm{a}) \\
\text { SB } & 79(\mathrm{a}) \\
\text { SB } & 64 \\
\text { SB } & 64(\mathrm{~b}) \\
\text { SB } & 79\end{array}$ & $\begin{array}{l}4.2 \\
5.5 \\
4.5 \\
6.5 \\
3.1 \\
5.3 \\
5.3 \\
6.2 \\
\end{array}$ & $\begin{array}{l}21 \\
15 \\
27 \\
15 \\
29 \\
21 \\
28 \\
21 \\
\end{array}$ & $\begin{array}{l}0.0095 \\
0.0133 \\
0.0074 \\
0.0133 \\
0.0069 \\
0.0095 \\
0.0072 \\
0.0095 \\
\end{array}$ & $\begin{array}{r}0.0135 \\
0.0162 \\
0.0145 \\
0.0180 \\
0.0113 \\
0.0160 \\
0.0160 \\
0.0173 \\
\end{array}$ & $\begin{array}{l}0.71 \\
0.82 \\
0.51 \\
0.73 \\
0.61 \\
0.60 \\
0.45 \\
0.55 \\
\end{array}$ & $\stackrel{D}{\sim}$ \\
\hline $\begin{array}{l}\text { Series SB Avg } \\
(\text { Std. Dev.) }\end{array}$ & $\begin{array}{c}5.1 \\
(1.1)\end{array}$ & & $\begin{array}{c}0.0096 \\
(0.0025)\end{array}$ & 0.0154 & 0.63 & \\
\hline
\end{tabular}

(a) During first hour

(b) During second hour 
TABLE 17. Summary of Gas Phase Mass Transfer Coefficients

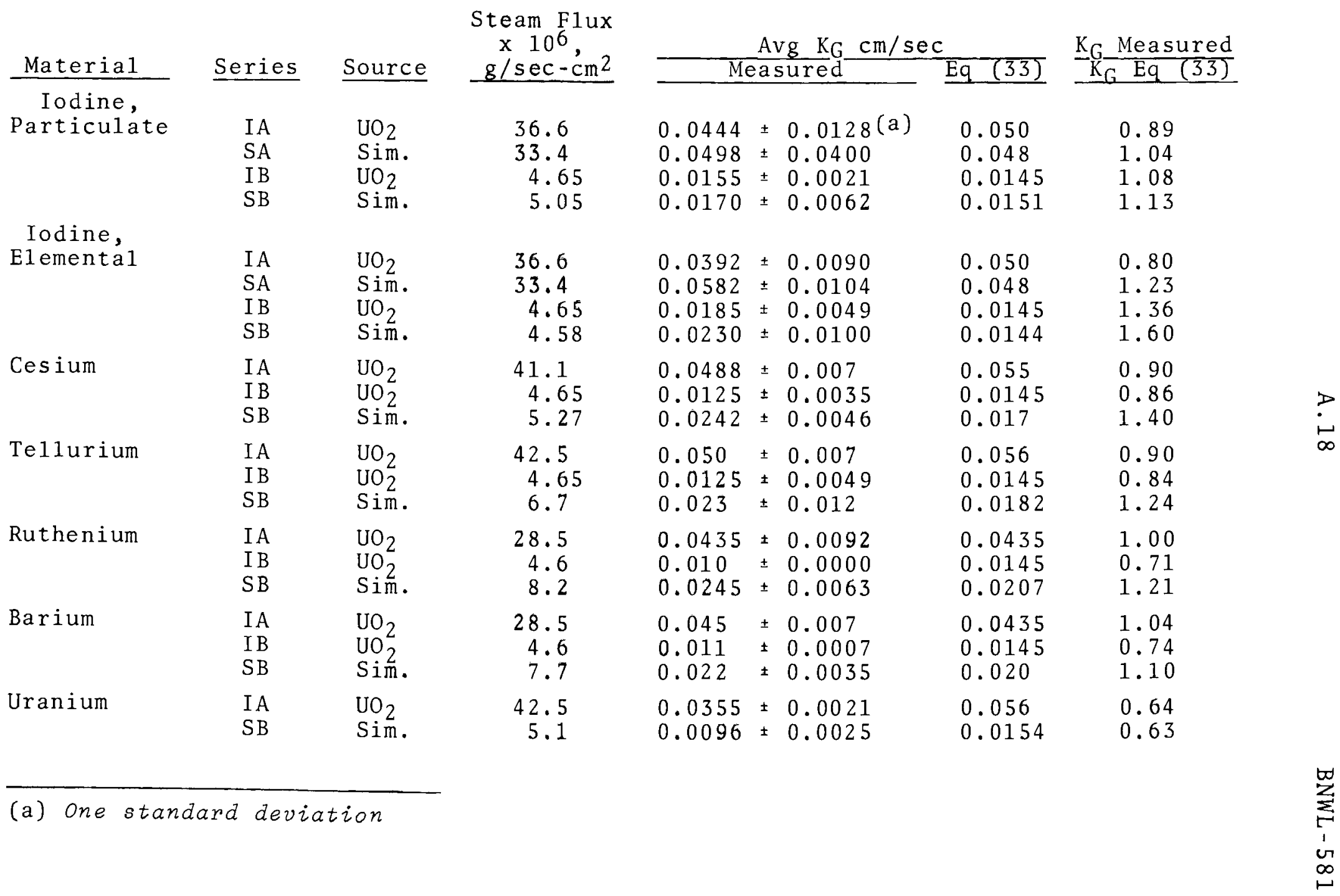


TABLE 18. Comparison of $K_{G}$ for Various Aerosol Components

Aerosol Component

Particulate Iodine

Elemental Iodine

Cesium

Tellurium

Ruthenium

Barium

Uranium

Me an

(Excluding Uranium)

$\mathrm{K}_{\mathrm{G}-(\mathrm{cm} / \mathrm{sec}), \text { Average of A11 B Series }}$
0.016
0.021
0.018
0.018
0.017
0.016
0.010
0.0177

$?$

岂 
TABLE 19. Gas-Liquid Partition Coefficients for Elemental Iodine

\begin{tabular}{c}
$\frac{\text { Run }}{\text { Irradiated }}$ \\
\hline IA 26 \\
IA 32 \\
IA 33 \\
IA 39 \\
IA 40 \\
IB 41 \\
IB 42 \\
Average \\
(Std. Dev.)
\end{tabular}

Simulant

SA 21

SA 23

SA 28

SA 43

SA 44

SB 48

SB 50

SB 53

SB 60

SB 61

SB 63

SB 64

SB 78

Average

(Std. Dev.)

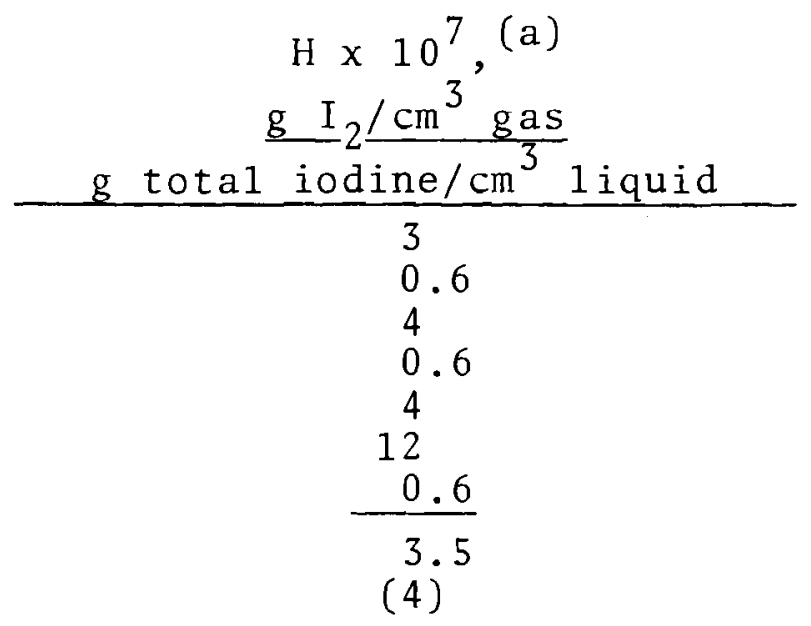

Theoretical, $\mathrm{pH} 7,80{ }^{\circ} \mathrm{C}^{(\mathrm{b})}$

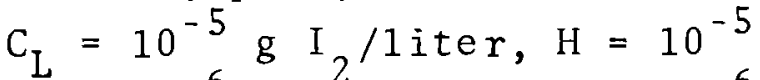

$$
\begin{aligned}
& C_{L}=10^{-6} \mathrm{~g} \mathrm{I}_{2}^{2} / 1 \text { iter, } H=10^{-6} \\
& \mathrm{C}_{\mathrm{L}}=10^{-7} \mathrm{~g} \mathrm{I}_{2} / 1 \text { iter, } \mathrm{H}=10^{-7} \\
& C_{L}=10^{-8} \mathrm{~g} \mathrm{I}_{2} / 1 \text { iter, } H=10^{-8}
\end{aligned}
$$

\footnotetext{
(a) Calculated from Figures $B .1$ through $B .21$ by Equation (38)

(b) Estimated from Reference 22
} 
TABLE 20. Iodine Distribution in Containment Vessel After $5 \mathrm{Hr}$

Percent of Mass Injected

$\frac{\text { Run }}{\text { Irradiated }}$

Gas Phase Sump Surfaces

IA 26

IA 32

IA 33

IA 39

IA 40

IA Average (a)

(Std. Dev.)

0.3

0.4

1

0.3

$\frac{1}{0.6}$

$(0.37)$

80

20

87

63

60

13

IB 41

IB 42

2.3

0.2

1.2

$\frac{11}{60}$

(29)

36
40

I B Average

(Std. Dev.)

$(1.5)$

$\frac{88}{39.4}$

Simulant

$\begin{array}{ll}\text { SA } & 21 \\ \text { SA } & 23 \\ \text { SA } & 28 \\ \text { SA } & 43 \\ \text { SA } & 44\end{array}$

SA Average

(Std. Dev.)

SB 48

SB 50

SB 53

SB 60

SB 61

SB 63

SB 64

SB 74

SB Average

(Std. Dev.)
0.1

0.04

0.9

0.02

0.07

0.23

$(0.37)$

0.1

0.1

0.03

0.05

0.1

0.06

0.6

0.05

0.14

(0.18)
61

$\frac{67}{64}$

(4.2)

73

93

92

93

97

90

$(9.5)$

37

$\frac{33}{35}$

(2.8)

60

81

77

90

62

90

77

$\frac{77}{77}$

(11)
27

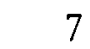

7

7

$\frac{3}{10}$

10

$(9.5)$

40

19

23

10

38

10

22

23

23

(11)

(a) If Run IA 40 is omitted:
Series IA Avg 0.5
(Std. Dev.) (0.33)

72

(13)
27

(13) 
TABLE 21. Cesium Distribution in Containment Vessel After $5 \mathrm{Hr}$

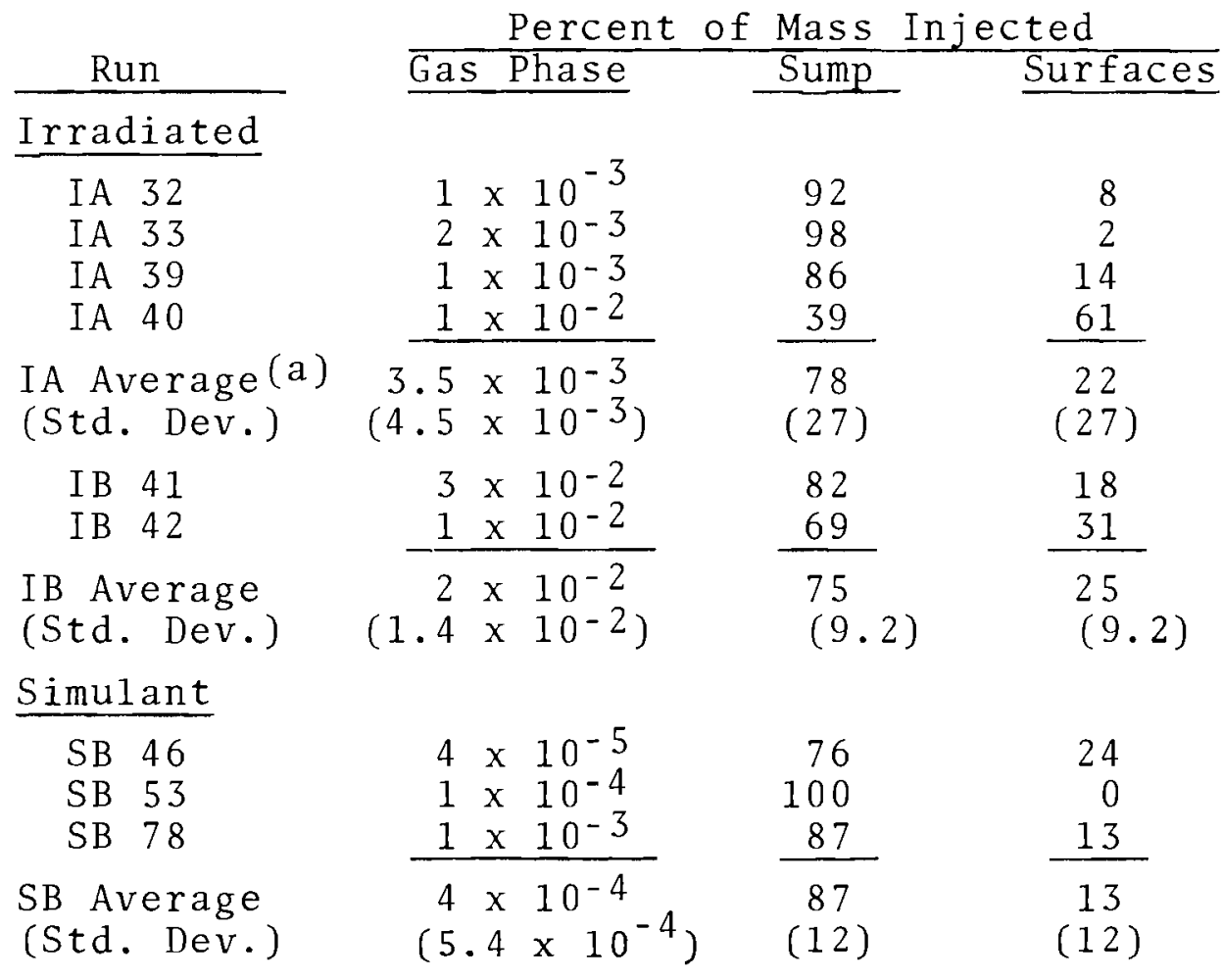

(a) If Run IA 40 is omitted: Series IA $\begin{array}{cc}\text { Avg } & 1.3 \times 10^{-3} \\ \text { (Std. }) & \left(5.4 \times 10^{-4}\right. \\ \text { Dev. } & \end{array}$ $92 \quad 8$ (6) (6) 
TABLE 22. Telzurium Distribution in Containment Vessel After $5 \mathrm{Hr}$

$\frac{\text { Run }}{\text { Irradiated }}$

IA 32

IA 33

IA Average (Std. Dev.)

$\begin{array}{ll}\text { I B } & 41 \\ \text { I B } & 42\end{array}$

IB Average

(Std. Dev.)

Simulant

SB 47

$\mathrm{SB} 53$

SB Average

(Std. Dev.)
Percent of Mass Injected

Gas Phase Sump Surfaces

$\frac{2 \times 10^{-2}}{2 \times 10^{-2}}$

$1 \times 10^{-3}$

\begin{tabular}{lll}
$1 \times 10^{-1}$ \\
\hline $5 \times 10^{-2}$
\end{tabular}

$\left(7 \times 10^{-2}\right)$

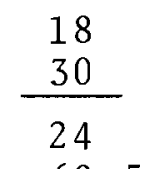

(8.5)

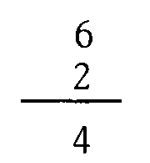

(2.8)

\begin{tabular}{l}
82 \\
70 \\
\hline 76 \\
$(8.5)$ \\
94 \\
98 \\
\hline 96 \\
$(2.8)$
\end{tabular}

81

$\frac{95}{88}$

(10)

TABLE 23. Ruthenium Distribution in Containment Vessel After $5 \mathrm{Hr}$

Run

Irradiated

IA 39

IA 40

IA Average

(Std. Dev.)

I B 41

IB 42

I B Average

(Std. Dev.)

$\underline{\text { Simulant }}$

SB 52

SB 53

SB Average

(Std. Dev.)

$$
\begin{array}{lll}
1 & \times 10^{-2} \\
3 & \times 10^{-5} \\
\hline 5 \times 10^{-3} \\
\left(7 \times 10^{-3}\right)
\end{array}
$$


TABLE 24. Barium Distribution in Containment Vessel After $5 \mathrm{Hr}$

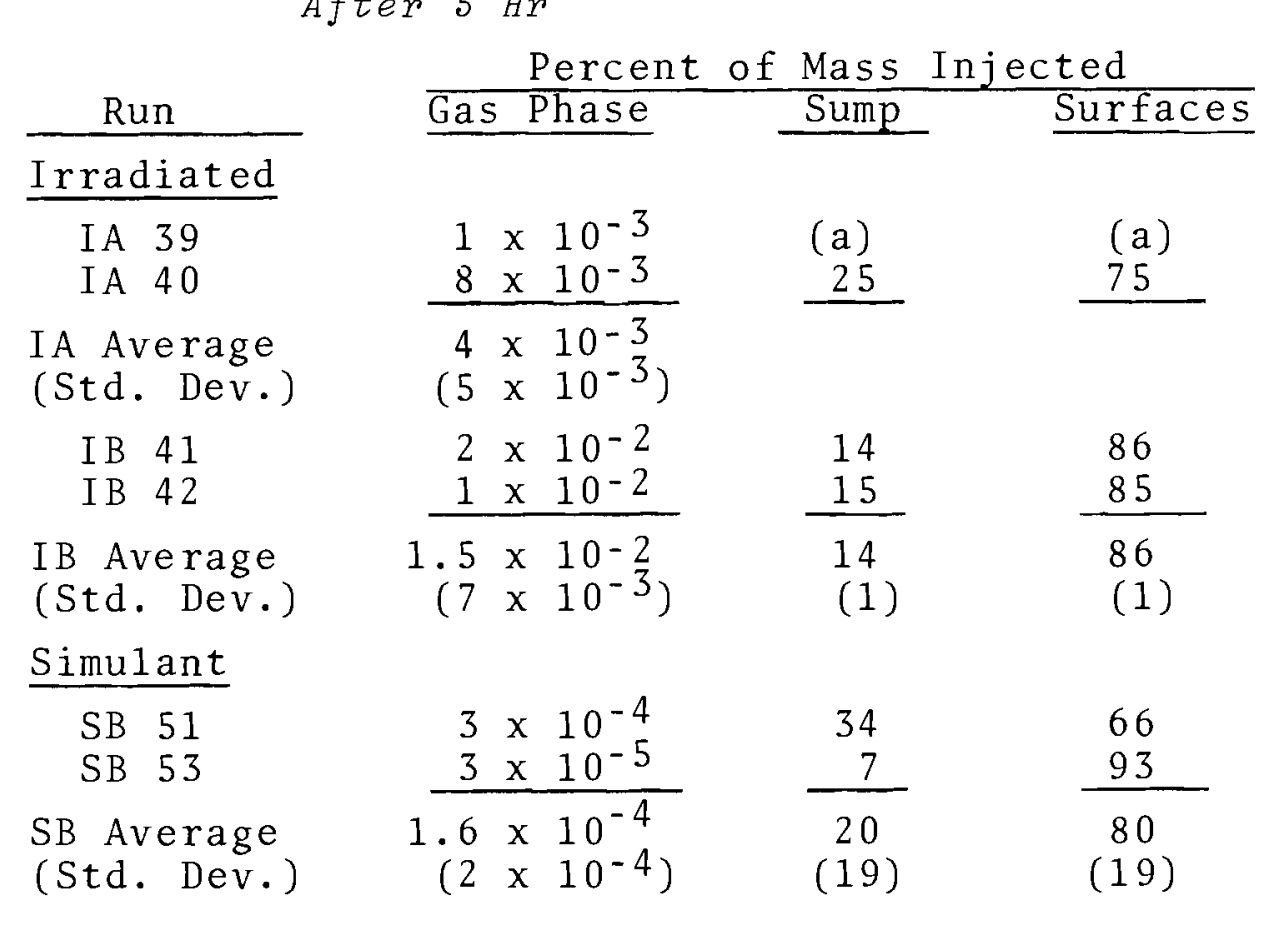

(a) Insufficient analyses

TABLE 25. Uranium Distribution in Containment Vessel After $5 \mathrm{Hr}$

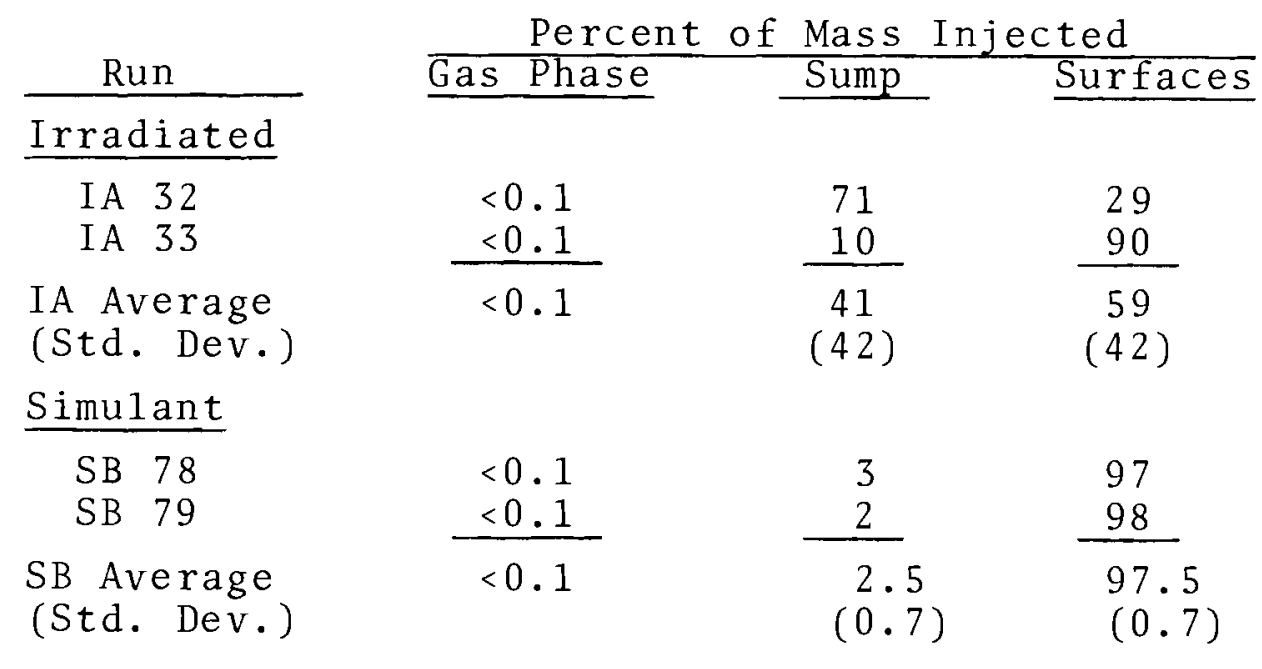


TABLE 26. Summary of Distributions After 5 hr Containment Aging

\begin{tabular}{|c|c|c|c|c|c|}
\hline \multirow[b]{2}{*}{ Material } & \multirow[b]{2}{*}{ Series } & \multicolumn{4}{|c|}{ Average Percent of Mass Injected } \\
\hline & & In Gas Phase & In & Sump & On Surfaces \\
\hline \multirow[t]{4}{*}{ Iodine } & IA & $0.5 \pm 0.33$ & 72 & \pm 13 & $27 \pm 13$ \\
\hline & $\mathrm{SA}$ & $0.23 \pm 0.37$ & 90 & \pm 9 & $10 \pm 9$ \\
\hline & IB & $1.2 \pm 1.5$ & 64 & \pm 4 & $35 \pm 3$ \\
\hline & SB & $0.14 \pm 0.18$ & 77 & \pm 11 & $23 \pm 11$ \\
\hline \multirow[t]{3}{*}{ Cesium } & IA & $\left(13 \pm 5 \times 10^{-4}\right)$ & 92 & \pm 6 & $8 \pm 6$ \\
\hline & IB & $\left(2 \pm 1.4 \times 10^{-2}\right)$ & 75 & \pm 9 & $25 \pm 9$ \\
\hline & SB & $\left(4 \pm 5 \times 10^{-4}\right)$ & 87 & \pm 12 & $13 \pm 12$ \\
\hline \multirow[t]{3}{*}{ Tellurium } & I A & $\left(2 \pm 0 \times 10^{-2}\right)$ & 24 & \pm 9 & $76 \pm 9$ \\
\hline & IB & $\left(5 \pm 7 \times 10^{-2}\right)$ & 4 & \pm 3 & $96 \pm 3$ \\
\hline & $\mathrm{SB}$ & $\left(5 \pm 7 \times 10^{-3}\right)$ & 12 & \pm 10 & $88 \pm 10$ \\
\hline \multirow[t]{3}{*}{ Ruthenium } & IA & $\left(7 \pm 4 \times 10^{-5}\right)$ & 32 & \pm 28 & $68 \pm 28$ \\
\hline & IB & $\left(5 \pm 1.4 \times 10^{-2}\right)$ & 5 & \pm 3 & $95 \pm 3$ \\
\hline & SB & $\left(2.5 \pm 3.5 \times 10^{-2}\right)$ & 14 & \pm 11 & $86 \pm 11$ \\
\hline \multirow[t]{3}{*}{ Barium } & IA & $\left(4 \pm 5 \times 10^{-3}\right)$ & 25 & & 75 \\
\hline & IB & $\left(15 \pm 7 \times 10^{-3}\right)$ & 14 & \pm 1 & $86 \pm 1$ \\
\hline & $\mathrm{SB}$ & $\left(1.6 \pm 2 \times 10^{-4}\right)$ & 20 & \pm 19 & $80 \pm 19$ \\
\hline \multirow[t]{2}{*}{ Uranium } & IA & $<0.1$ & 41 & \pm 42 & $59 \pm 42$ \\
\hline & SB & $<0.1$ & & $5 \pm 0.7$ & $97.5 \pm 1$ \\
\hline
\end{tabular}


TABLE 27. Solubility in Steam Condensate After 10 min Containment Time

\begin{tabular}{ll} 
& \multicolumn{4}{c}{ Percent of Material in Condensate } \\
Removed by Filtering
\end{tabular}

$\underline{\text { Irradiated }}$

IA 26

IA 32

I A 33

I A 39

IA 40

IA Average

IB 41

IB 42

IB Average

Simulant

$\begin{array}{ll}\text { SB } & 46 \\ \text { SB } & 47 \\ \text { SB } & 48 \\ \text { SB } & 50 \\ \text { SB } & 51 \\ \text { SB } & 52 \\ \text { SB } & 53 \\ \text { SB } & 60 \\ \text { SB } & 61 \\ \text { SB } & 63 \\ \text { SB } & 64 \\ \text { SB } & 78\end{array}$

SB Average
0.5

$$
2
$$

0.7

0.5

$\frac{70}{0.92}(\mathrm{a})$
0.6
2

50

3

$\frac{0.1}{1.6}$

3
3

$\frac{3}{3}$

5

0.1

18

1

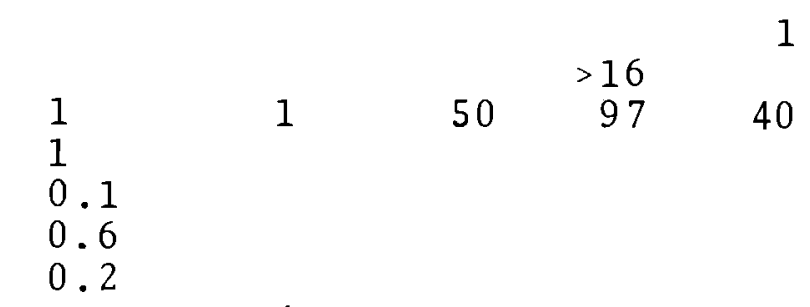

$\frac{4}{3.3}$

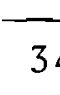

98

98

$>94$

$>98$$$
6
$$

$\frac{99}{53}$

$\frac{90}{90}$

$\overline{>96}$

$\begin{array}{lll}80 & 99 & 20\end{array}$

$\frac{98}{89} \quad \frac{99}{99} \quad \frac{50}{35}$ 
TABLE 28. Solubility in Steam Condensate After $5 \mathrm{hr}$ Containment Time

Percent of Material in Condensate Removed by Filtering

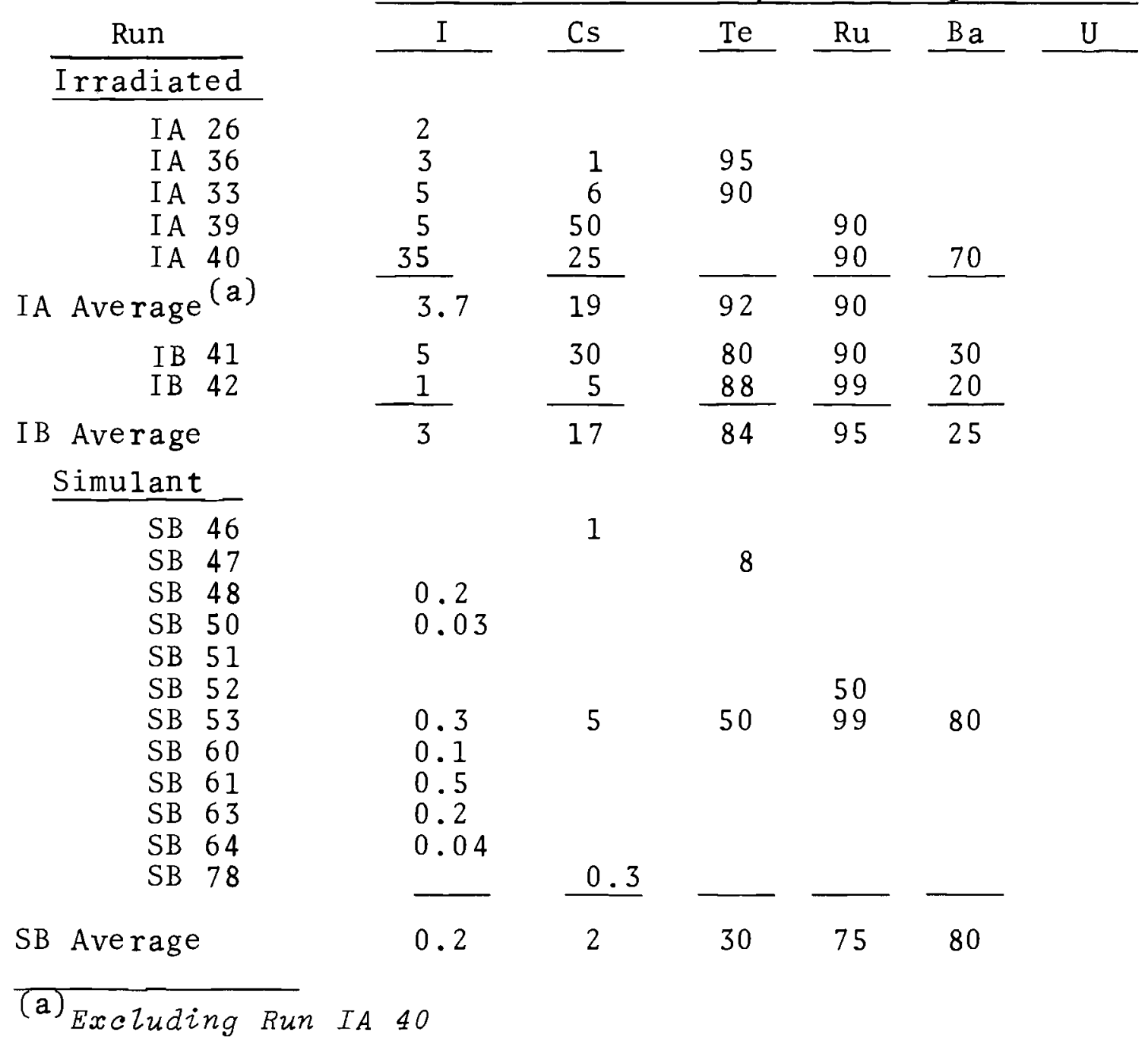


TABLE 29. Iodine Form in Condensate as Measured by Extraction(a)

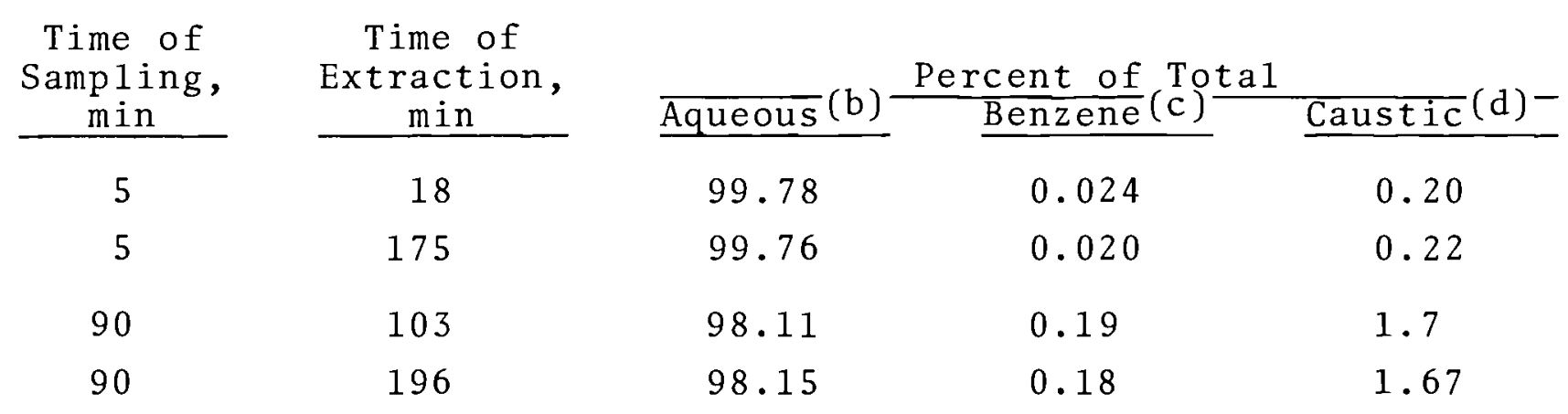
(a) Run 65, simulant iodine
(b) Probably ionic iodine
(c) After caustic back extraction. Probably organic iodine.
(d) Back extraction of benzene fraction. Probably elemental iodine. 
TABLE 30. Overall Material Recovery

$\underline{\text { Run }}$

Irradiated

IA 26

IA 32

IA 33

IA 39

IA 40

IB 41

IB 42

IA Average

Simulant

$\begin{array}{ll}\text { SA } & 21 \\ \text { SA } & 23 \\ \text { SA } & 28 \\ \text { SA } & 43 \\ \text { SA } & 44 \\ \text { SB } & 46 \\ \text { SB } & 47 \\ \text { SB } & 48 \\ \text { SB } & 50 \\ \text { SB } & 51 \\ \text { SB } & 52 \\ \text { SB } & 53 \\ \text { SB } & 60 \\ \text { SB } & 61 \\ \text { SB } & 63 \\ \text { SB } & 64 \\ \text { SB } & 74\end{array}$

$\mathrm{SB}$ Ave rage
Mass Accounted for (Percent of Injected)

I $\stackrel{\mathrm{Cs}}{\mathrm{Te}} \stackrel{\mathrm{Ru}}{\mathrm{Ba}}$

82

88

153

65

18

92

82

83

100

25

32

93

33

93

$\frac{79}{83}$

34

$\begin{array}{ll}65 & 104\end{array}$

$18 \quad 71$

$20 \quad 31$

$\frac{16}{27} \quad \frac{34}{34} \quad \frac{43}{62}$

50

100

170

94

102

87

96

91

89

88

80

100

95

94

91
40

103

$\begin{array}{rrr} & 109 & 40 \\ 23 & 16 & 20\end{array}$

$\overline{56} \quad \overline{62} \quad \overline{30}$ 


\section{TABLE 31. Effect of Aerosol Complexity}

on Iodine Containment Behavior

Maypack Analysis at

Vesse 1 In1et, $\%$ Iodine

Filter

Silver Screens

Charcoal Paper

Charcoal Bed

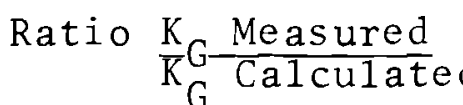

Total Iodine

Particulate Iodine

Elemental Iodine

Distribution after $5 \mathrm{hr}$, \%

Gas Phase

Vesse 1 Sump

Surfaces

H, Gas-Liquid Distribution Coefficient

Percent Removed from Condensate

by Filtering

at $10 \mathrm{~min}$

at $5 \mathrm{hr}$

Overa11 Recovery, $\%$ of Injected

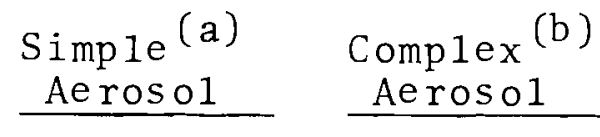

46

52

1.8

50

43

0.2

0.6

1.03

1.04

1.19

1.00

1.02

1.07

?

\begin{tabular}{|c|c|}
\hline $\begin{array}{l}0.2 \\
81 \\
19\end{array}$ & $\begin{array}{l}0.7 \\
63 \\
36\end{array}$ \\
\hline $2 \times 10^{-7}$ & $3 \times 10^{-7}$ \\
\hline $\begin{array}{l}0.4 \\
0.2\end{array}$ & $\frac{1}{3} \cdot 1$ \\
\hline 96 & 84 \\
\hline
\end{tabular}

81

19

(a) $I_{2}+S S-U 0_{2}$, average of Runs $28,43,44,48,50$, and 61 .

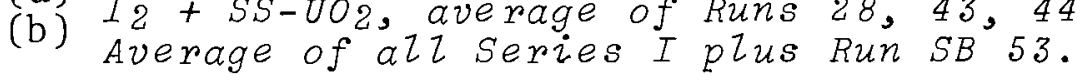


TABLE 32. Effect of Cladding Type on Iodine Behavior

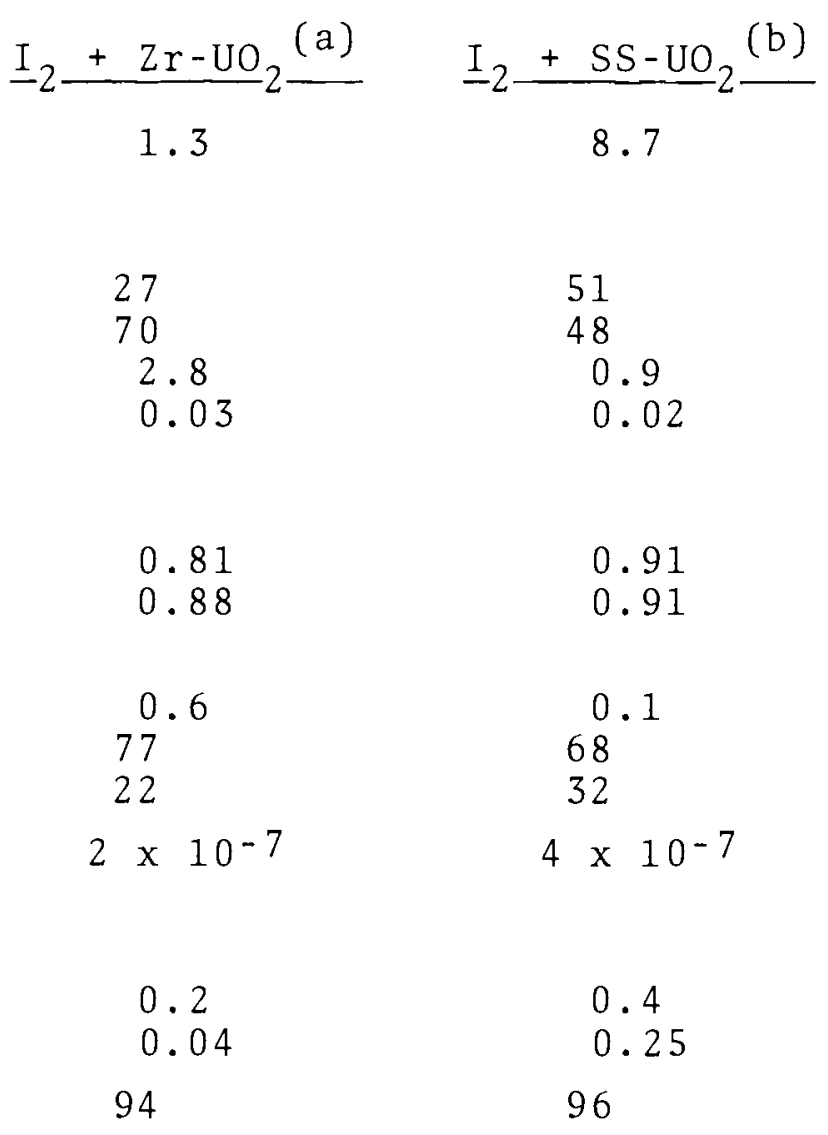

Distribution after $5 \mathrm{hr}$, $\frac{0}{0}$

Gas Phase

Vesse1 Sump

Surfaces

H, Gas-Liquid Distr. Coef.

Percent Removed from Condensate

by Filtering

at $10 \mathrm{~min}$

0.04

0.25

Overa11 Recovery, of Injected

(a) Run $S B 64$

(b) Average of Runs $S B 48, S B 50$, and $S B 61$ 
TABLE 33. Comparison of Iodine Behavior in Containment Vessels with Fresh Versus Aged Painted Walls(a)

\begin{tabular}{|c|c|c|c|}
\hline & $\begin{array}{l}\text { SA } 21 \\
\text { Fresh } \\
\text { Paint }\end{array}$ & $\begin{array}{l}\text { SA } 23 \\
\text { Aged } \\
\text { Paint }\end{array}$ & $\begin{array}{r}\text { SA } 43 \\
\text { Wel1-Aged } \\
\text { Paint } \\
\end{array}$ \\
\hline Previous Steam Exposure, $\mathrm{hr}^{(\mathrm{b})}$ & 0 & 24 & 462 \\
\hline $\begin{array}{c}\text { Maypack Analysis at Vessel } \\
\text { Inlet, } 0 \\
\text { Filter } \\
\text { Silver Screens } \\
\text { Charcoal Paper } \\
\text { Charcoal Bed }\end{array}$ & $\begin{array}{l}3 \\
97 \\
0.1 \\
0.01\end{array}$ & $\begin{array}{l}16 \\
84 \\
0.4 \\
0.08\end{array}$ & $\begin{array}{l}68 \\
30 \\
1.7 \\
0.4\end{array}$ \\
\hline \multicolumn{4}{|l|}{ 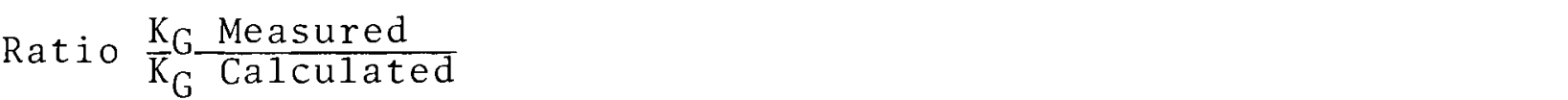 } \\
\hline $\begin{array}{l}\text { Total Iodine } \\
\text { Particulate Iodine } \\
\text { Elemental Iodine }\end{array}$ & $\begin{array}{l}1.12 \\
0.85 \\
1.17\end{array}$ & $\begin{array}{l}1.00 \\
1.00 \\
1.12\end{array}$ & $\begin{array}{l}1.33 \\
1.31 \\
1.50\end{array}$ \\
\hline $\begin{array}{c}\text { Distribution after } 5 \mathrm{hr}, \frac{\circ}{\text { Gas Phase }} \\
\text { Vessel Sump } \\
\text { Surfaces }\end{array}$ & $\begin{array}{l}0.1 \\
73 \\
27\end{array}$ & $\begin{array}{l}0.04 \\
93 \\
7\end{array}$ & $\begin{array}{l}0.02 \\
93 \\
7\end{array}$ \\
\hline $\begin{array}{l}\text { H, Gas-Liquid Distr. Coef. } \\
\text { Overall Recovery, } \% \text { of Injected }\end{array}$ & $\begin{array}{l}1 \times 10^{-7} \\
50\end{array}$ & $\begin{array}{l}1 \times 10^{-7} \\
100\end{array}$ & $\begin{array}{r}6 \times 10^{-8} \\
94\end{array}$ \\
\hline
\end{tabular}


TABLE 34. Effect of Long Inlet Line on Sampler

\begin{tabular}{|c|c|c|c|c|c|c|c|c|c|c|}
\hline \multirow[b]{2}{*}{ Sample } & \multicolumn{4}{|c|}{ Iodine Retained, $\frac{\circ}{6}$} & \multicolumn{3}{|c|}{$\begin{array}{l}\text { Gas Concentration } \\
\text { (arbitrary units) }\end{array}$} & \multicolumn{3}{|c|}{ 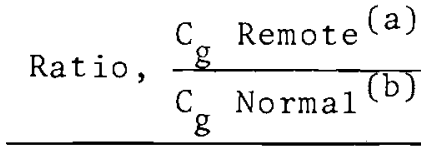 } \\
\hline & Filter & $\begin{array}{l}\text { Silver } \\
\text { Screens }\end{array}$ & $\begin{array}{l}\text { Charcoal } \\
\text { Paper } \\
\end{array}$ & $\begin{array}{l}\text { Charcoal } \\
\text { Bed } \\
\end{array}$ & $131 \mathrm{I}$ & ${ }^{137} \mathrm{Cs}$ & $129 \mathrm{Te}$ & $131_{I}$ & ${ }^{137} \mathrm{Cs}$ & $129 \mathrm{Te}$ \\
\hline \multicolumn{11}{|l|}{ Irradiated } \\
\hline $\begin{array}{l}\text { IA } 26-1 \\
\text { IA } 26-1 R(C)\end{array}$ & $\begin{array}{l}73 \\
80\end{array}$ & $\begin{array}{l}22 \\
12\end{array}$ & $\begin{array}{l}4 \\
7\end{array}$ & $\begin{array}{l}1 \\
1\end{array}$ & $\begin{array}{l}1.9 \\
2.1\end{array}$ & & & 1.1 & & \\
\hline $\begin{array}{l}\text { IA } 32-1 \\
\text { IA } 32-1 R\end{array}$ & $\begin{array}{l}72 \\
92\end{array}$ & $\begin{array}{r}10 \\
4\end{array}$ & $\begin{array}{r}15 \\
2\end{array}$ & $\begin{array}{l}3 \\
2\end{array}$ & $\begin{array}{l}6.27 \\
8.45\end{array}$ & $\begin{array}{l}1.77 \\
2.16\end{array}$ & $\begin{array}{l}4.17 \\
5.22\end{array}$ & 1.35 & 1.22 & 1.25 \\
\hline $\begin{array}{ll}\text { IA } & 32-7 \\
\text { IA } & 32-7 R\end{array}$ & $\begin{array}{l}0 \\
0.4\end{array}$ & $\begin{array}{l}0.9 \\
6.0\end{array}$ & $\begin{array}{r}7 \\
16\end{array}$ & $\begin{array}{l}92 \\
78\end{array}$ & $\begin{array}{l}2.07 \\
2.11\end{array}$ & $\begin{array}{l}4.3 \\
1.2\end{array}$ & $\begin{array}{l}1.3 \\
2.9\end{array}$ & 1.02 & 0.28 & 2.23 \\
\hline $\begin{array}{l}\text { IA } 33-4 \\
\text { IA } 33-4 R\end{array}$ & $\begin{array}{l}1.4 \\
0.3\end{array}$ & $\begin{array}{l}16 \\
10\end{array}$ & $\begin{array}{l}40 \\
54\end{array}$ & $\begin{array}{l}42 \\
36\end{array}$ & $\begin{array}{l}1.62 \\
2.77\end{array}$ & $\begin{array}{r}11.5 \\
3.05\end{array}$ & $\begin{array}{r}18.0 \\
8.7\end{array}$ & 1.70 & 0.27 & 0.47 \\
\hline $\begin{array}{l}\text { IA } 33-7 \\
\text { IA } 33-7 R\end{array}$ & $\begin{array}{l}0.5 \\
0.3\end{array}$ & $\begin{array}{r}1 \\
10\end{array}$ & $\begin{array}{l}27 \\
28\end{array}$ & $\begin{array}{l}71 \\
62\end{array}$ & $\begin{array}{l}1.83 \\
1.77\end{array}$ & $\begin{array}{l}1.3 \\
1.0\end{array}$ & $\begin{array}{r}11.0 \\
6.8\end{array}$ & 0.97 & 0.78 & 0.62 \\
\hline \multicolumn{6}{|l|}{$\underline{\text { Simulant }}$} & & & & 0.64 & 1.14 \\
\hline $\begin{array}{ll}\text { SA } & 23-2 \\
\text { SA } & 23-2 R\end{array}$ & $\begin{array}{l}23 \\
22\end{array}$ & $\begin{array}{l}48 \\
16\end{array}$ & $\begin{array}{r}9 \\
18\end{array}$ & $\begin{array}{l}20 \\
44\end{array}$ & $\begin{array}{l}1.35 \\
1.55\end{array}$ & & & 1.15 & & \\
\hline $\begin{array}{ll}\text { SA } & 23-5 \\
\text { SA } & 23-5 R\end{array}$ & $\begin{array}{l}1.3 \\
2.2\end{array}$ & $\begin{array}{l}38 \\
20\end{array}$ & $\begin{array}{l}11 \\
34\end{array}$ & $\begin{array}{l}50 \\
44\end{array}$ & $\begin{array}{l}3.34 \\
4.53\end{array}$ & & & 1.35 & & \\
\hline Average & & & & & & & & 1.25 & & \\
\hline
\end{tabular}

(a) Remote sample was a heated Maypack with 20 ft long inlet tube connecting to containment vessel.

(b) Normal sample was a Maypack inserted directly into containment atmosphere.

(c) $R$ signifies remote sample taken concurrently with normal sample. 
• 
APPENDIX B

FIGURES B. 1 THROUGH B.52 


\section{.}




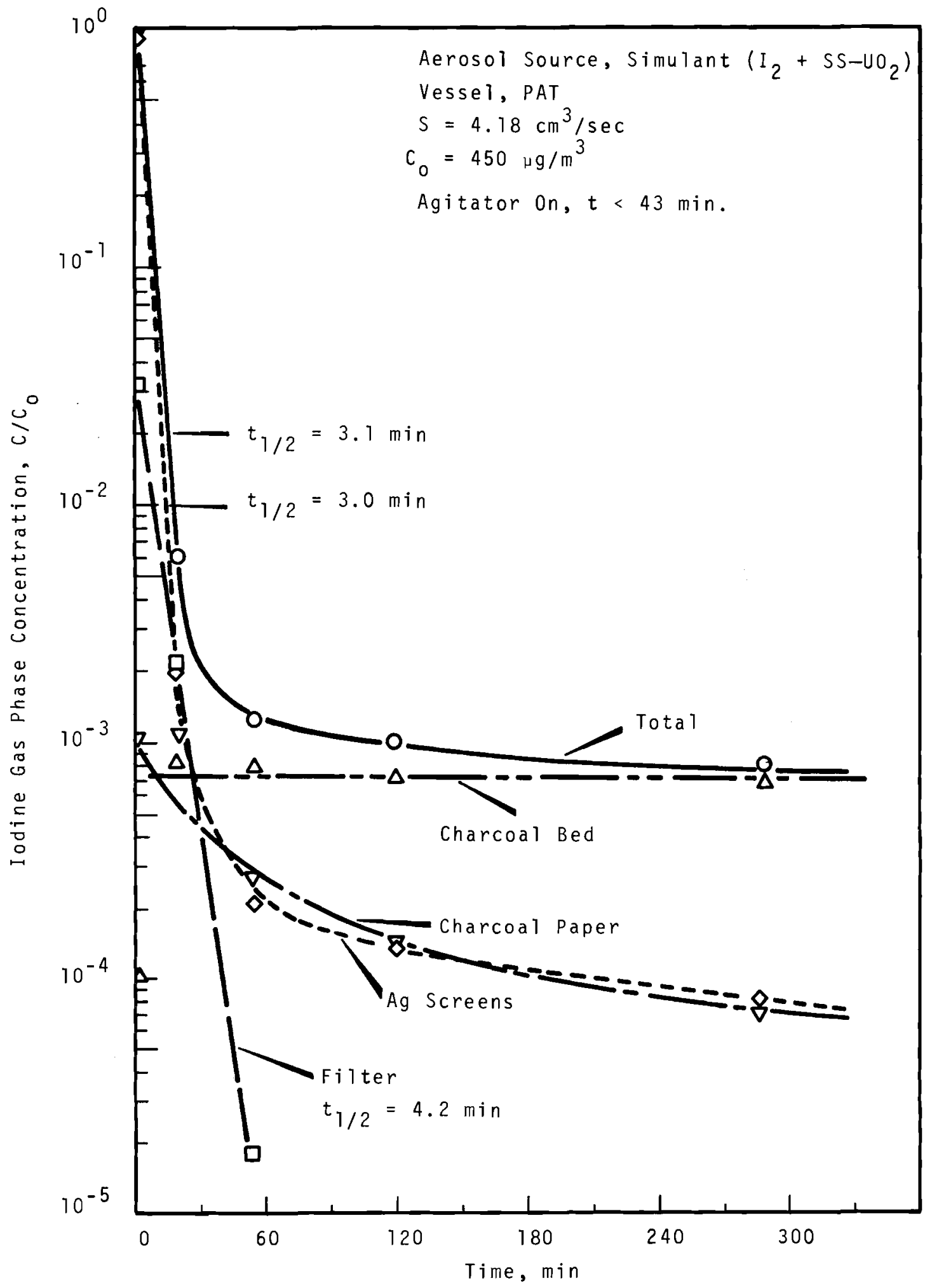

FIGURE B.1. Iodine Gas Phase Concentration, Run SA 21 
B. 2

BNWL - 581

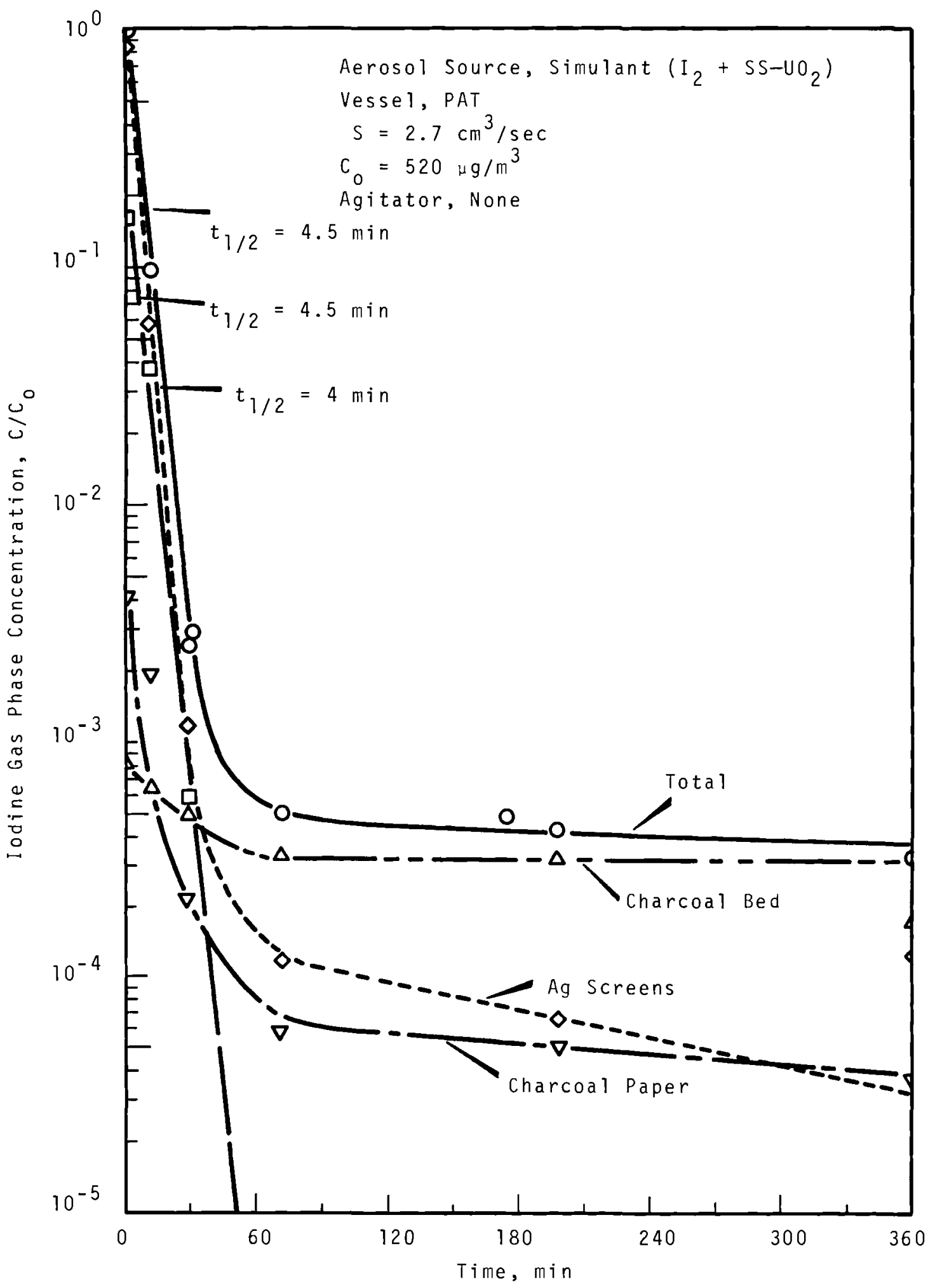

FIGURE B.2. Iodine Gas Phase Concentration, Run SA 23 


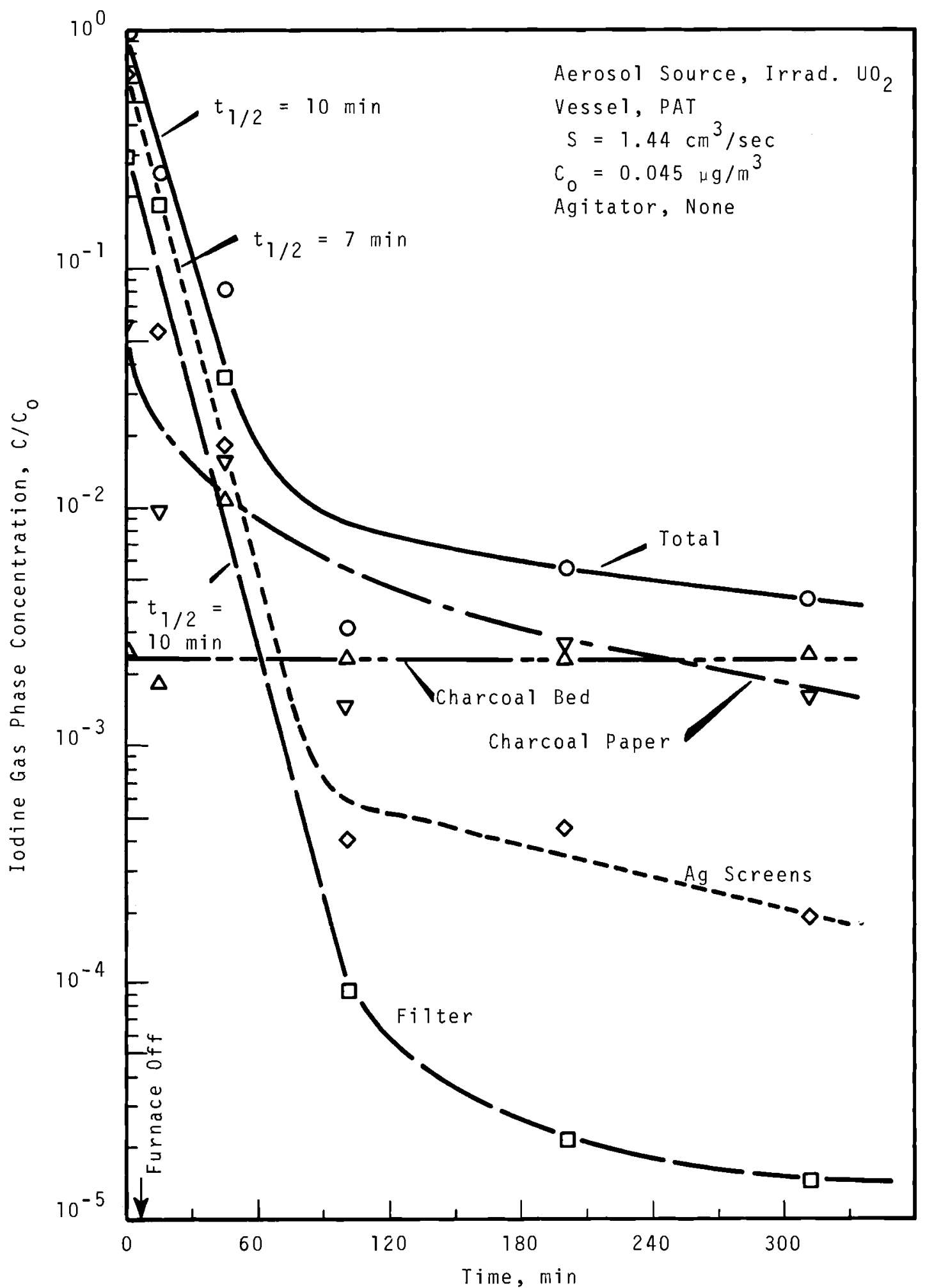

FIGURE B.3. Iodine Gas Phase Concentration, Run IA 26 


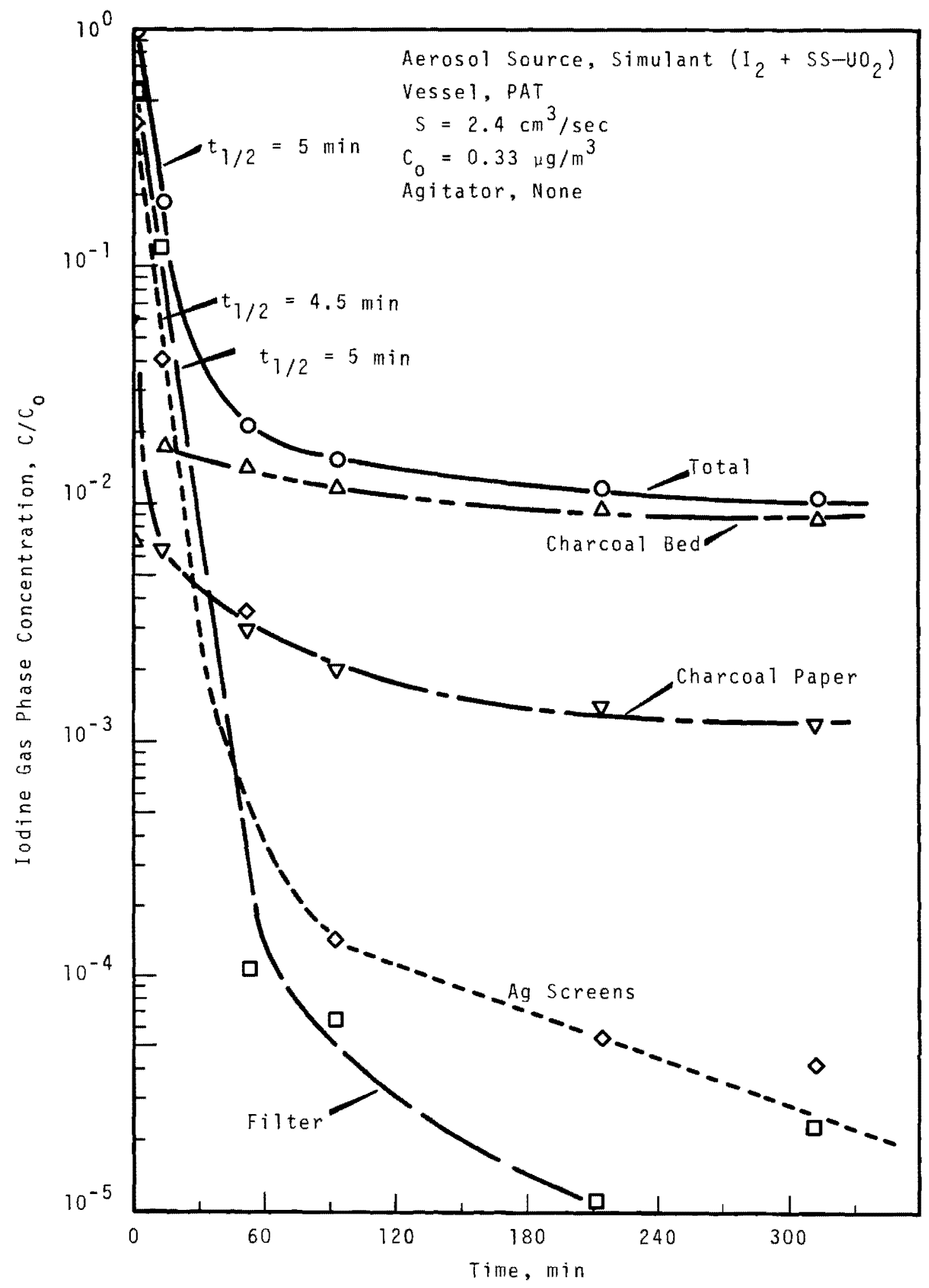

EIGURE B.4. Iodine Gas Phase Concentration, Run SA 28 


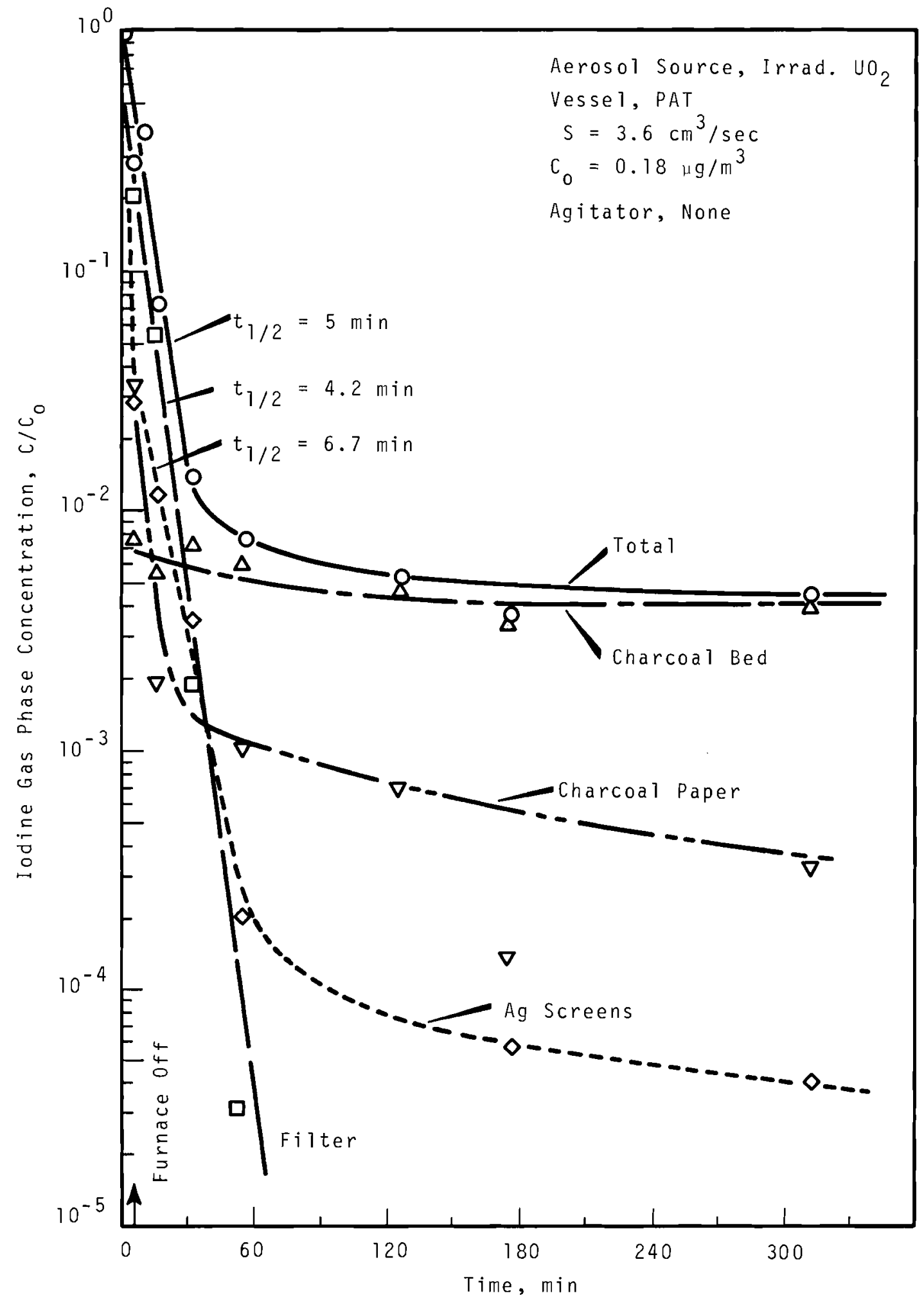

FIGURE B.5. Iodine Gas Phase Concentration, Run IA 32 
B. 6

BNWL- 581

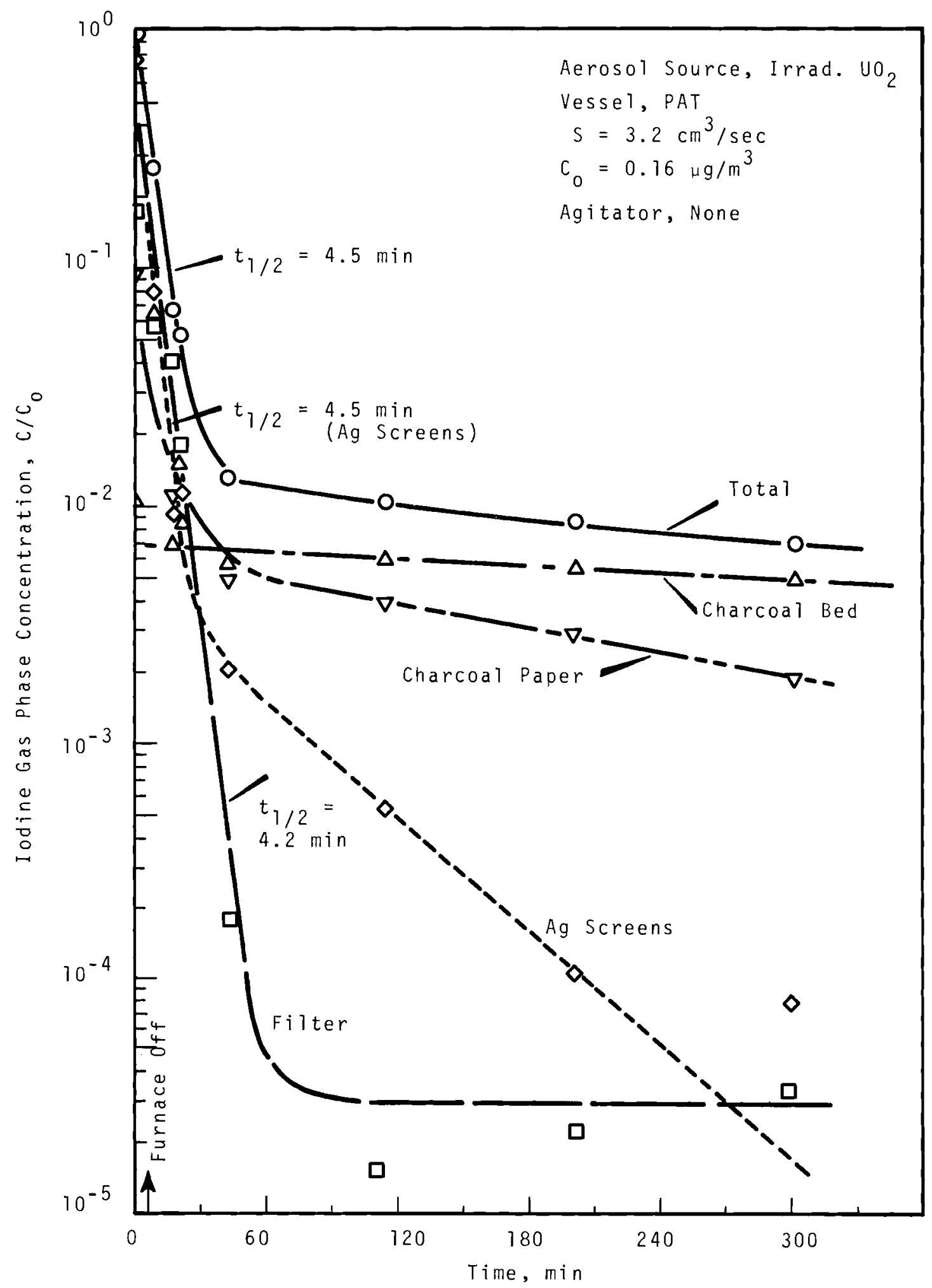

FIGURE B.6. Iodine Gas Phase Concentration, Run IA 33 


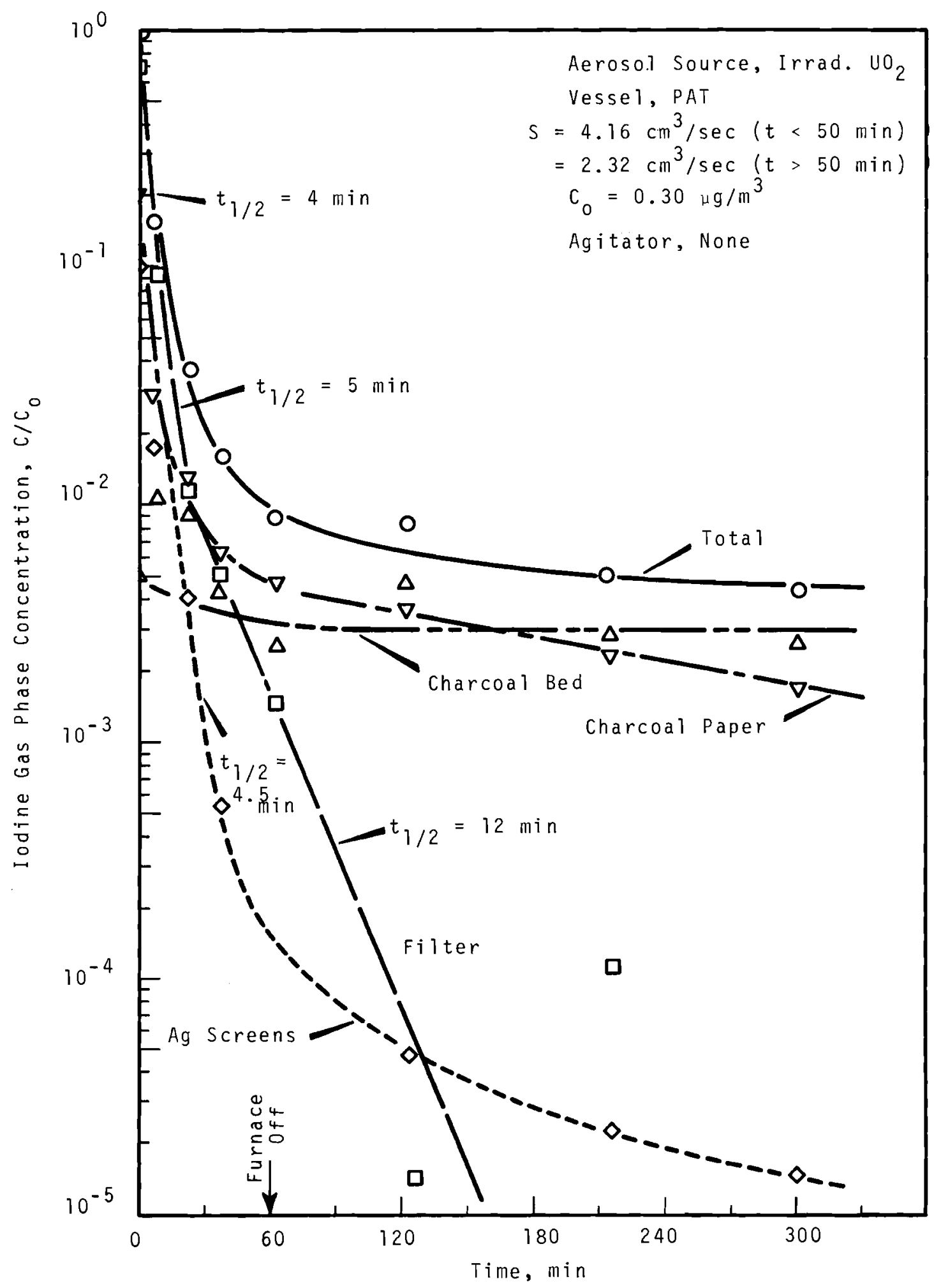

FIGURE B.?. Iodine Gas Phase Concentration, Run IA 39 


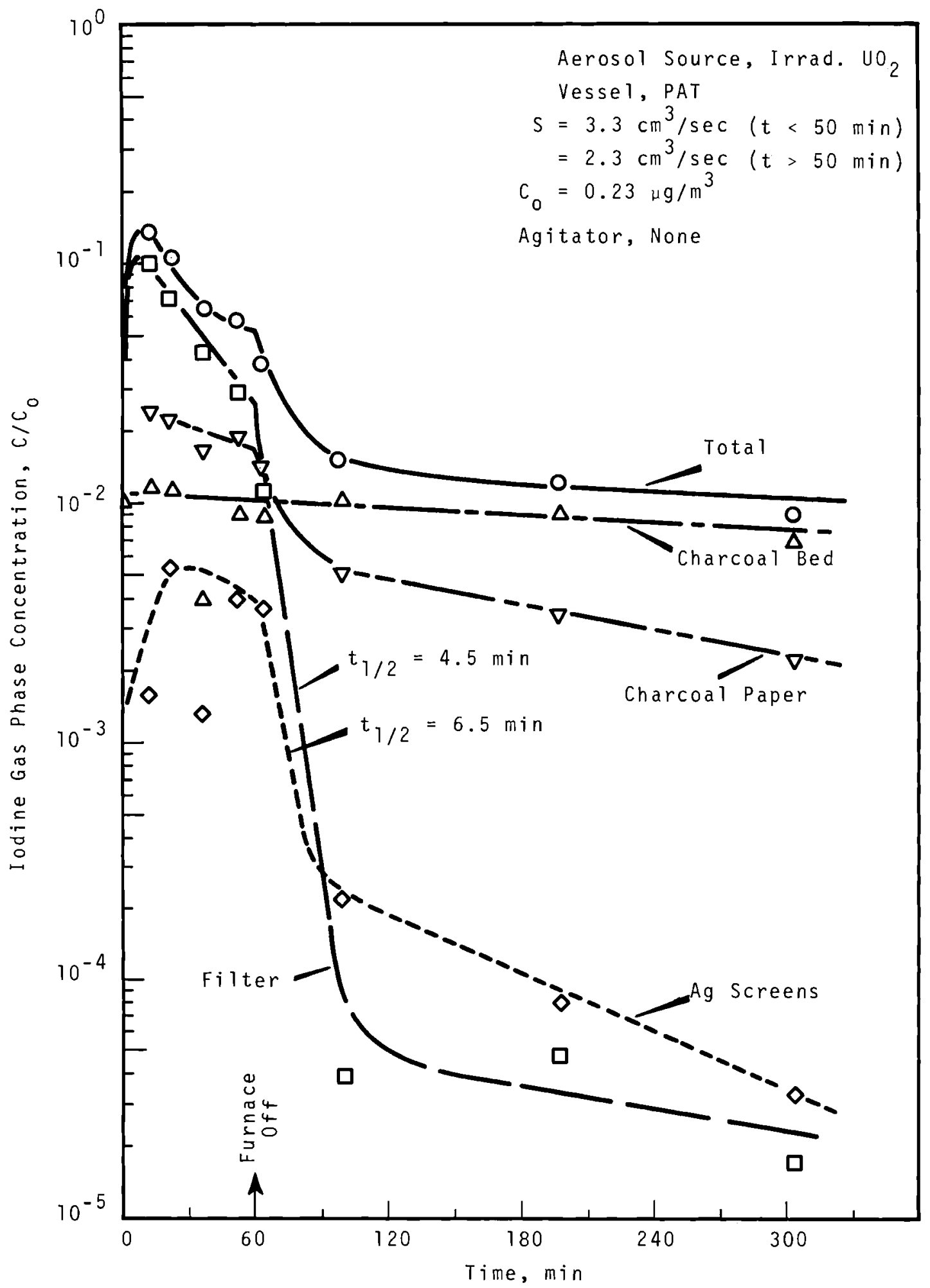

FIGURE B.8. Iodine Gas Phase Concentration, Run IA 40 


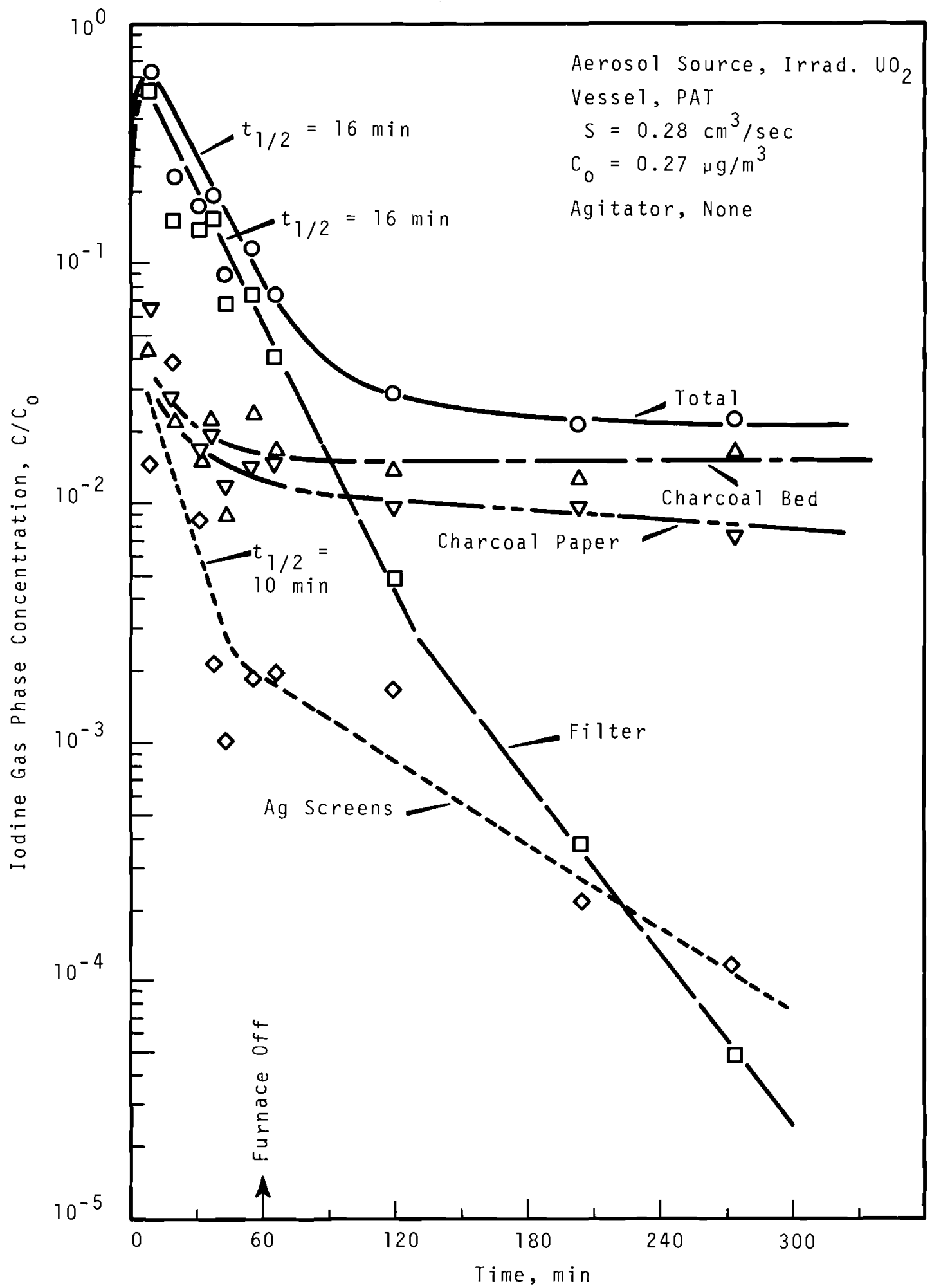

FIGURE B.9. Iodine Gas Phase Concentration, Run IB 41 


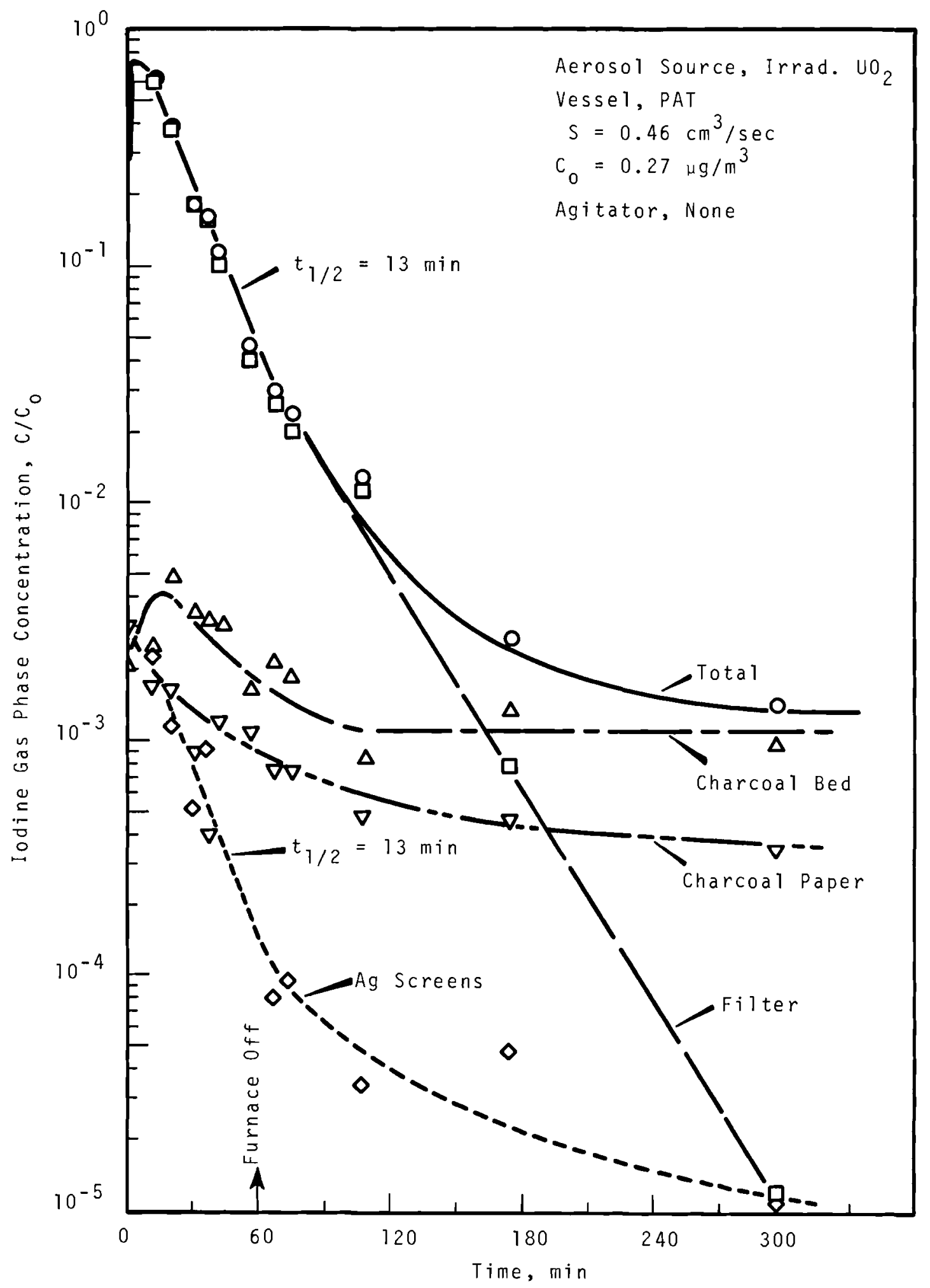

FIGURE B.10. Iodine Gas Phase Concentration, Run IB 42 


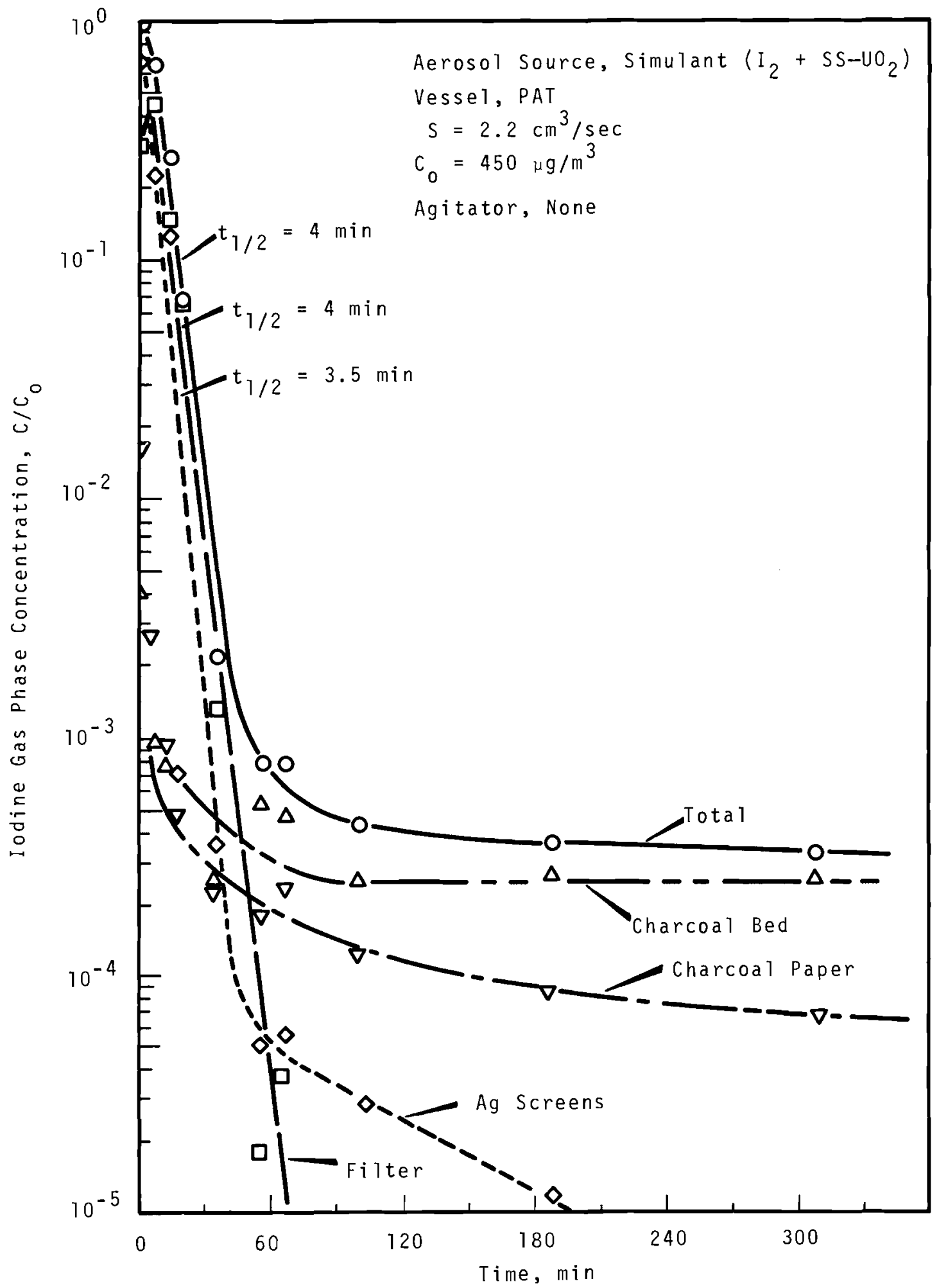

EIGURE B.11. Iodine Gas Phase Concentration, Run SA 43 


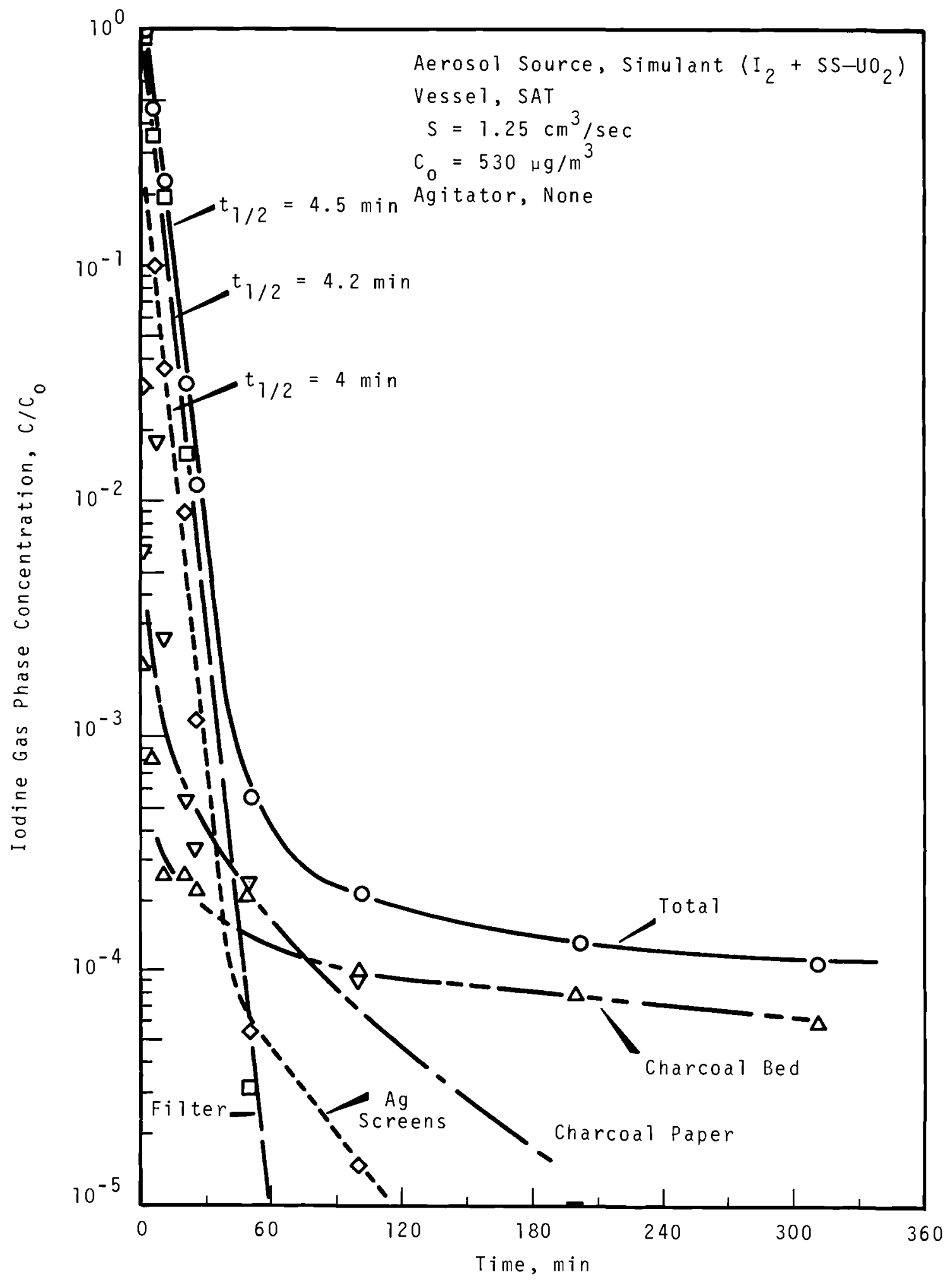

FIGURE B.12. Iodine Gas Phase Concentration, Run SA 44 


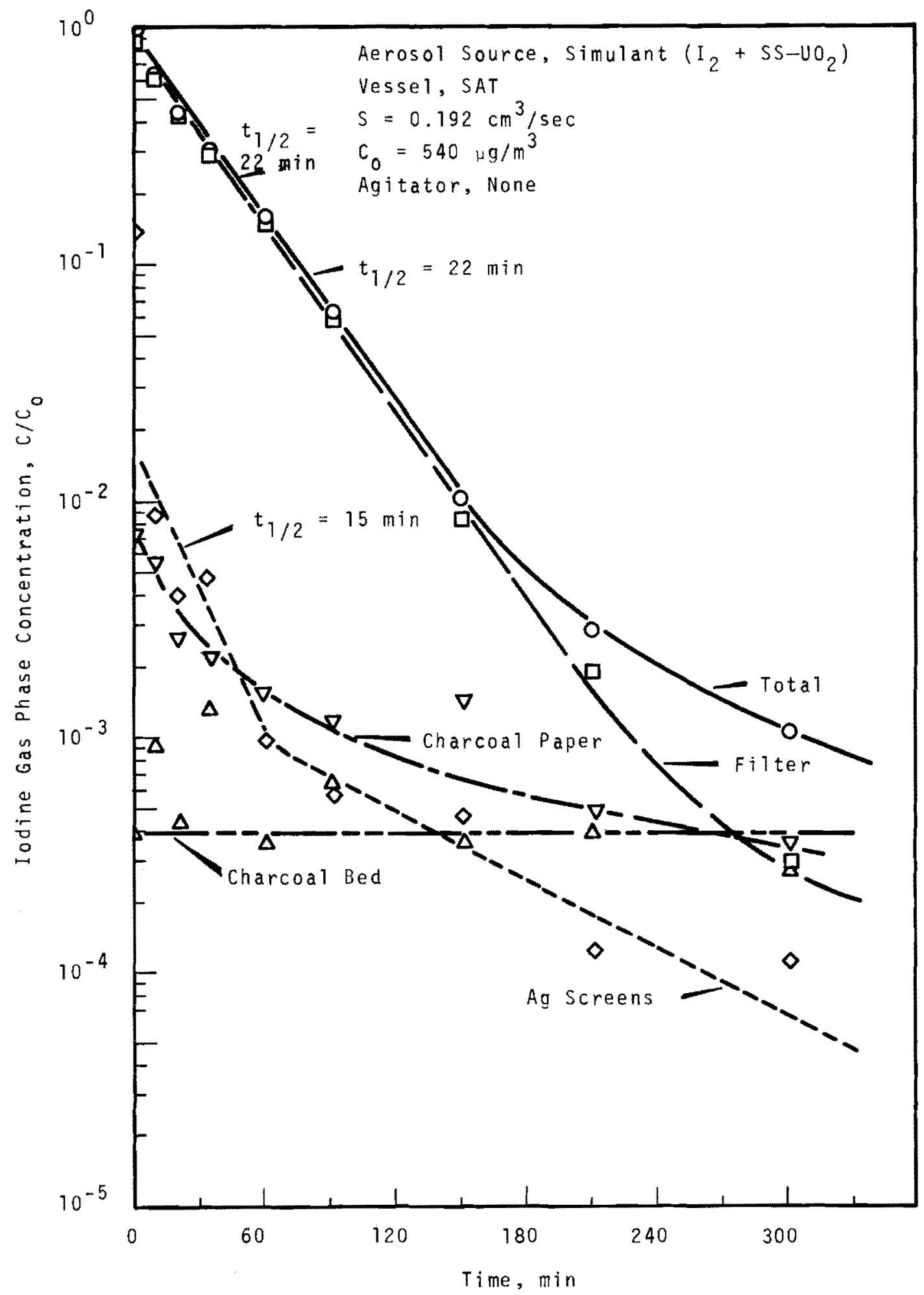

EIGURE B.13. Iodine Gas Phase Concentration, Run SB 48 


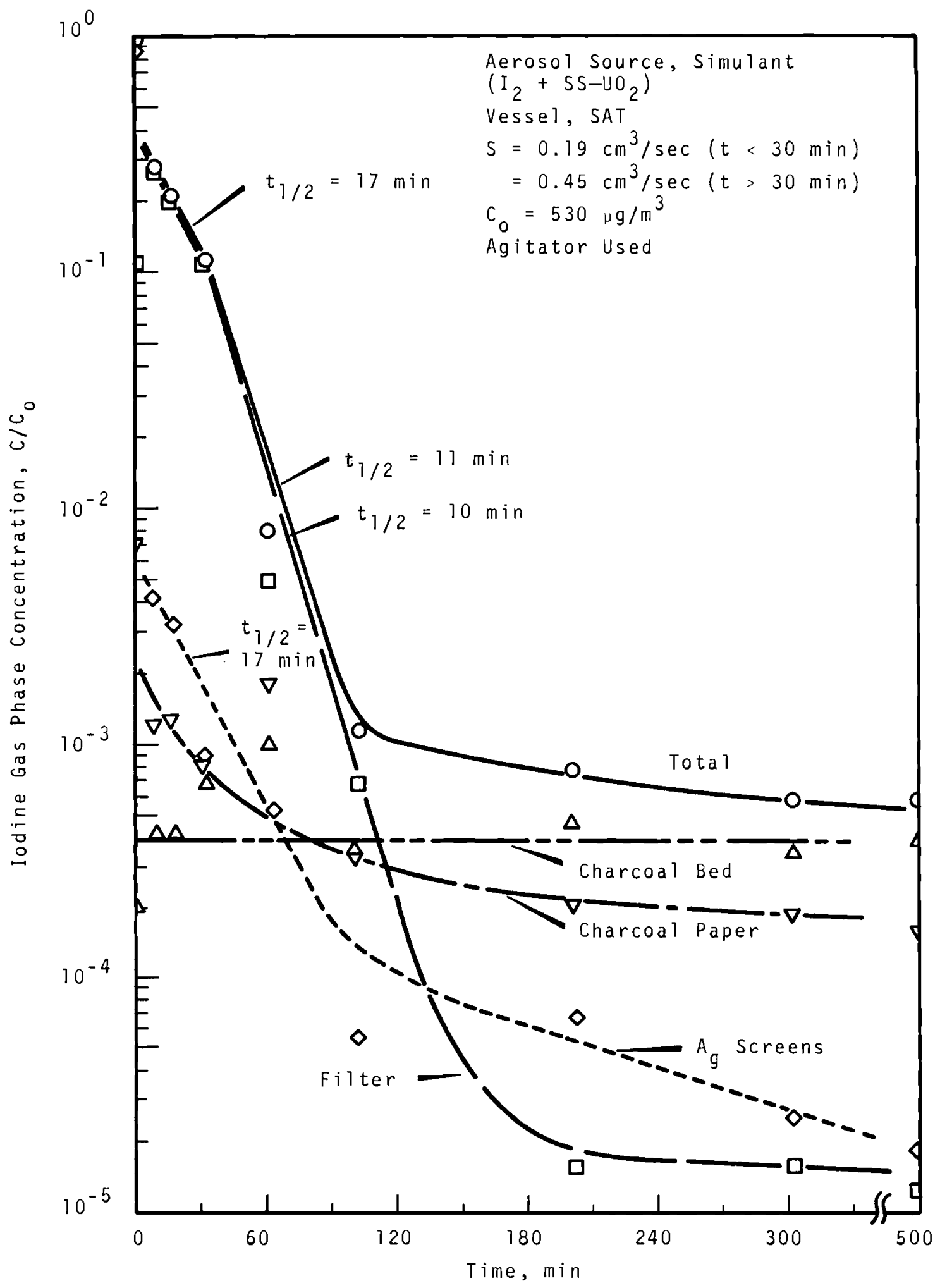

FIGURE B.14. Iodine Gas Phase Concentration, Run SB 50 


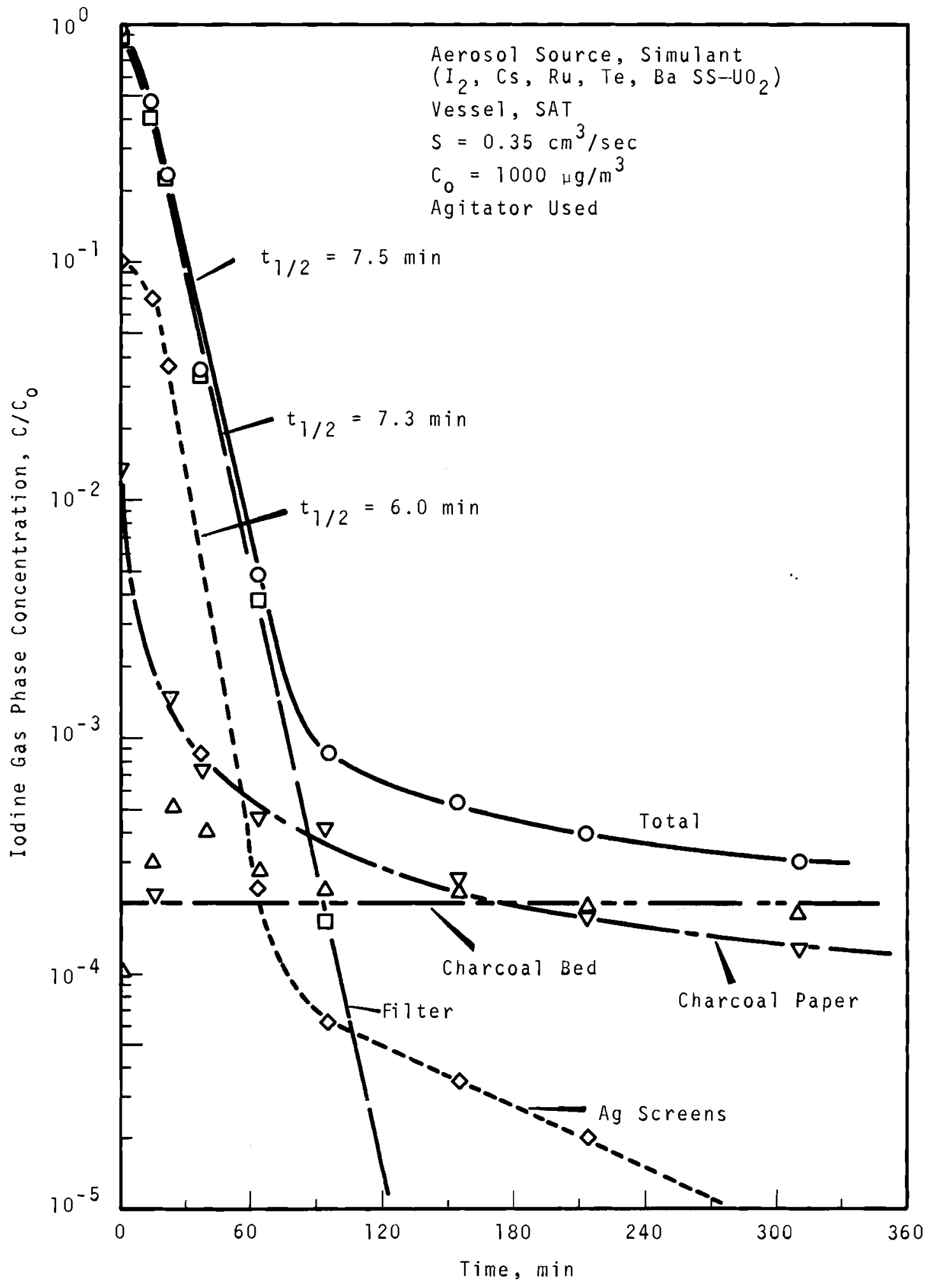

FIGURE B.15. Iodine Gas Phase Concentration, Run SB 53 


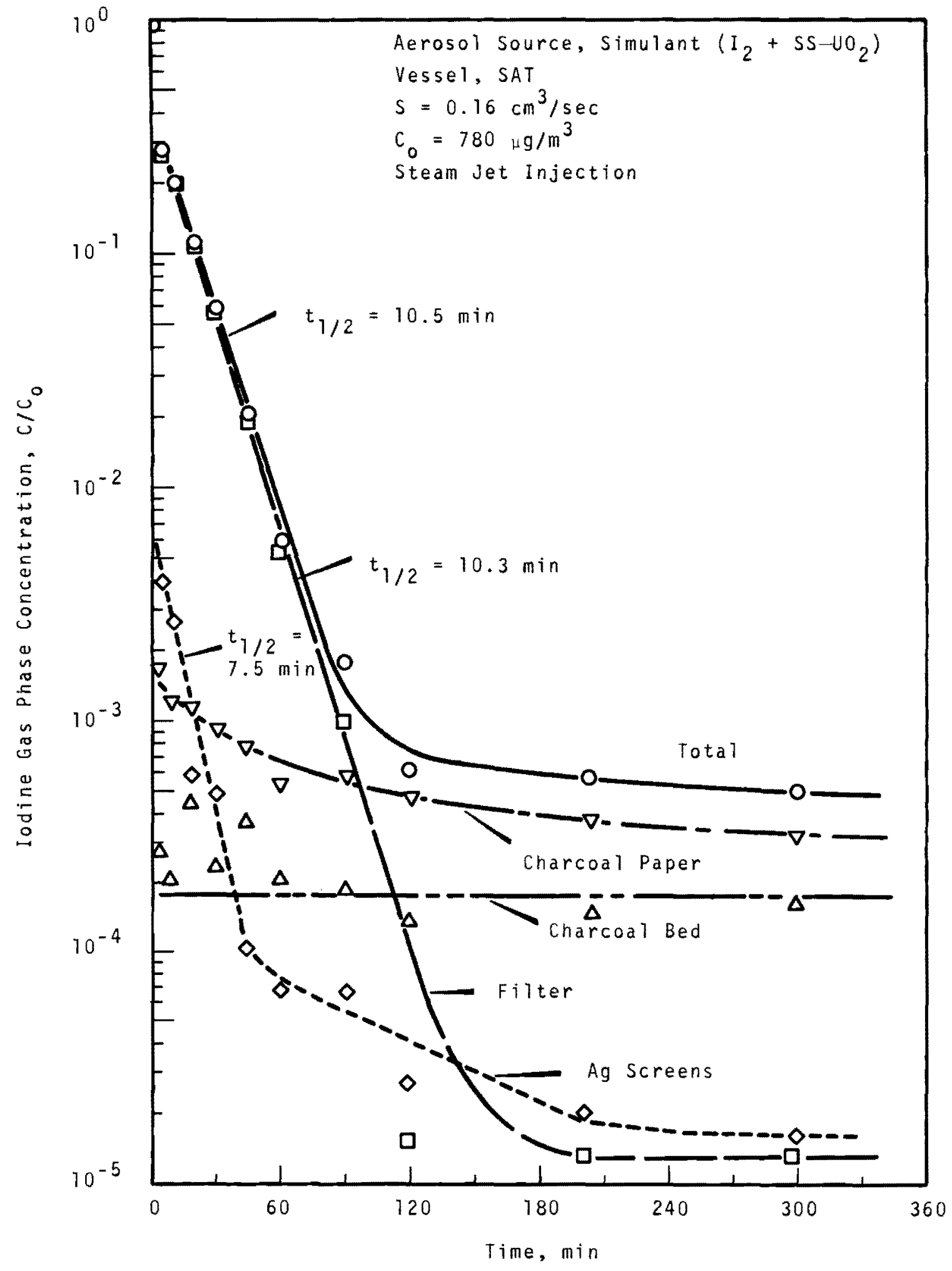

FIGURE B.16. Iodine Gas Phase Concentration, Run SB 60 


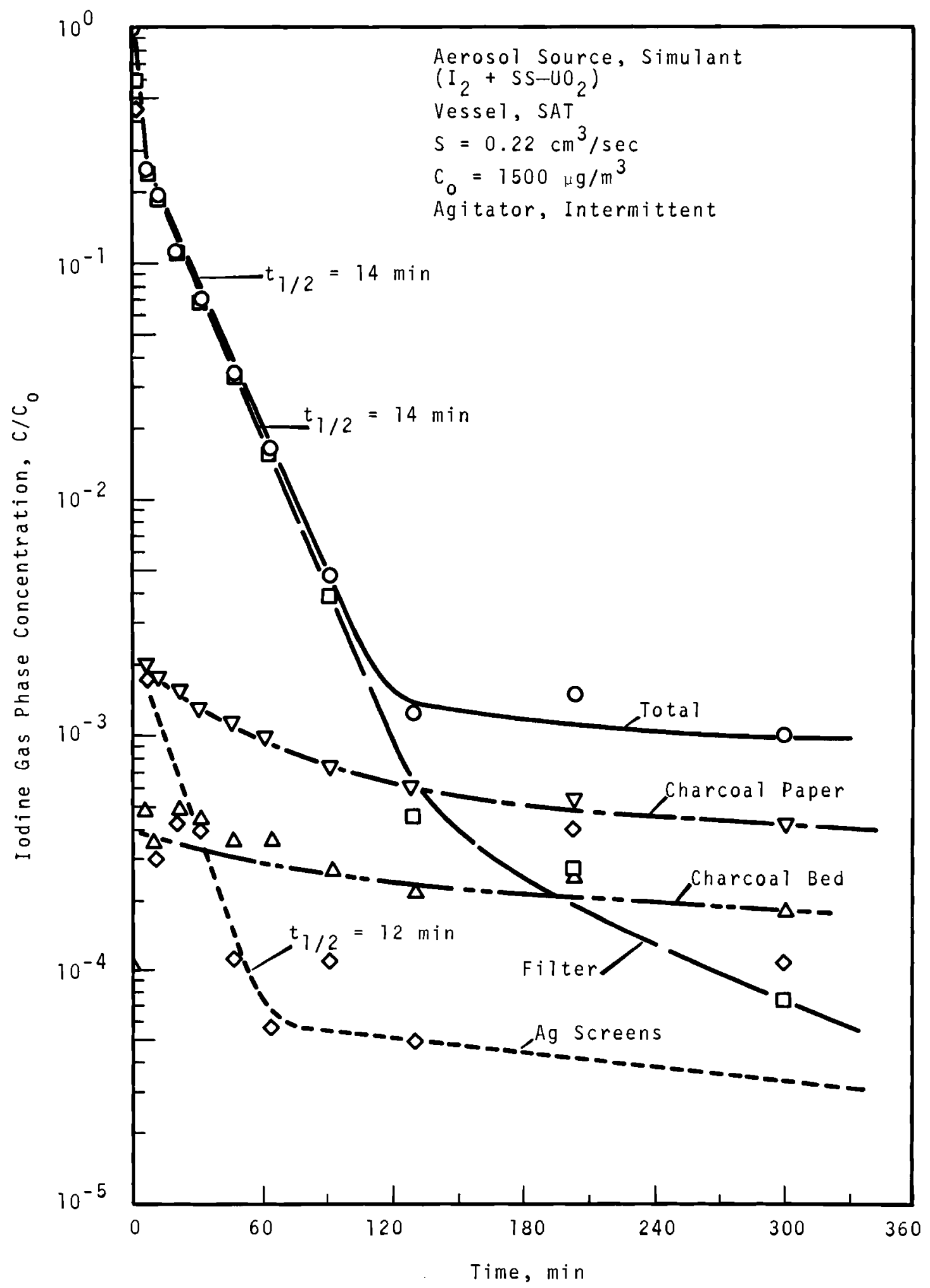

FIGURE B.17. Iodine Gas Phase Concentration, Run SB 61 


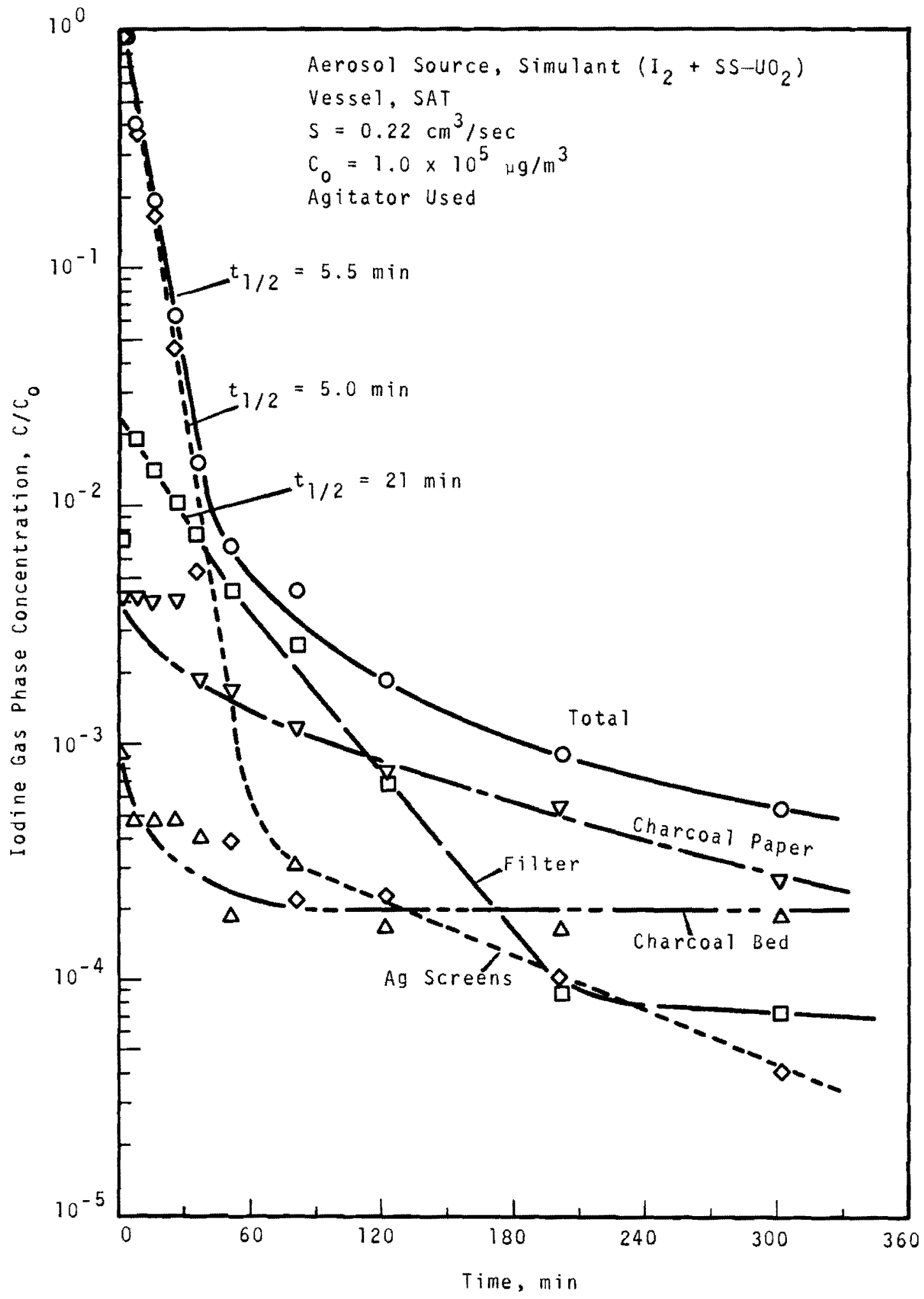

FIGURE B.18. Iodine Gas Phase Concentration, Run SB 63 


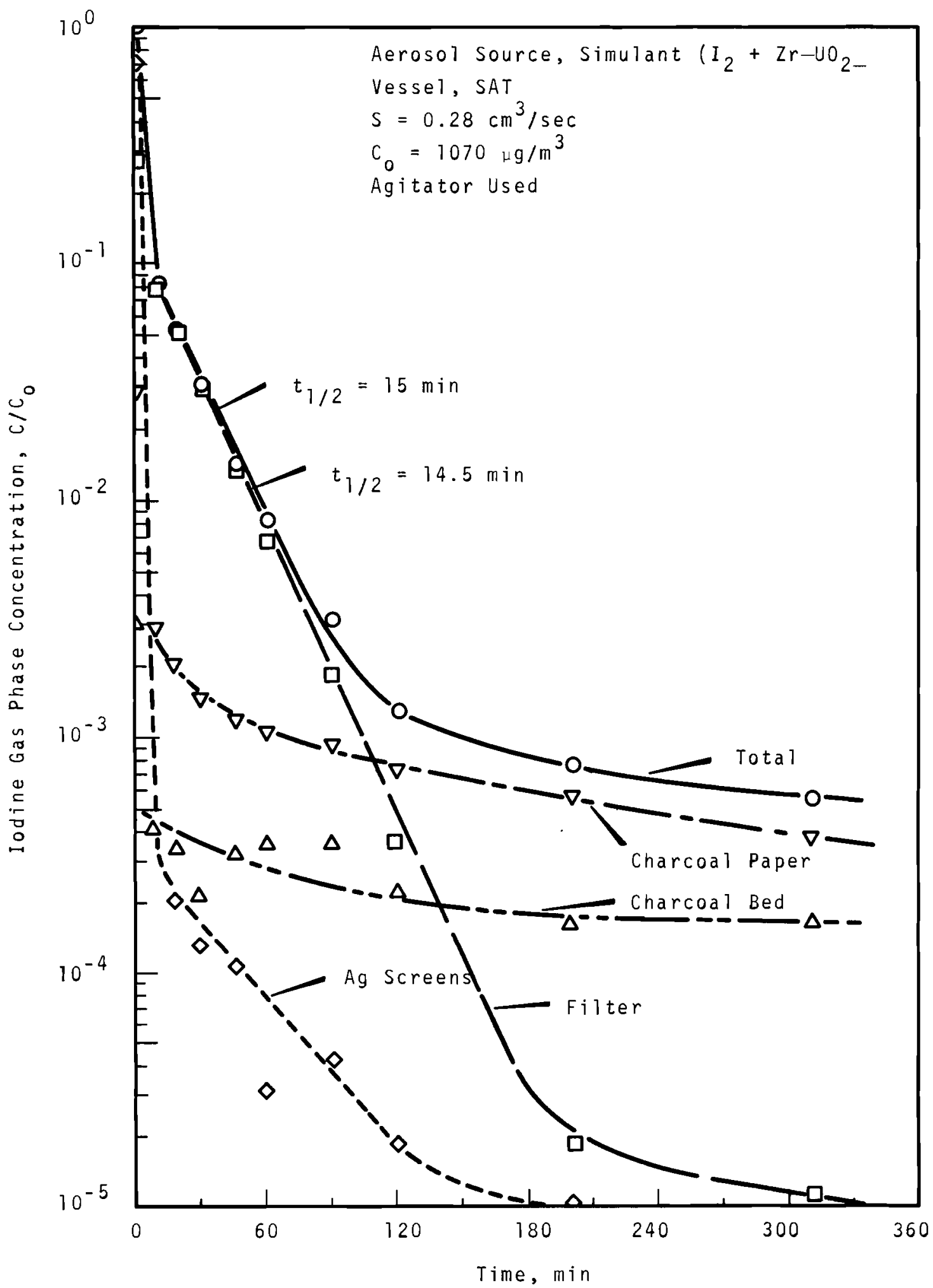

FIGURE B.19. Iodine Gas Phase Concentration, Run SB 64 
B. 20

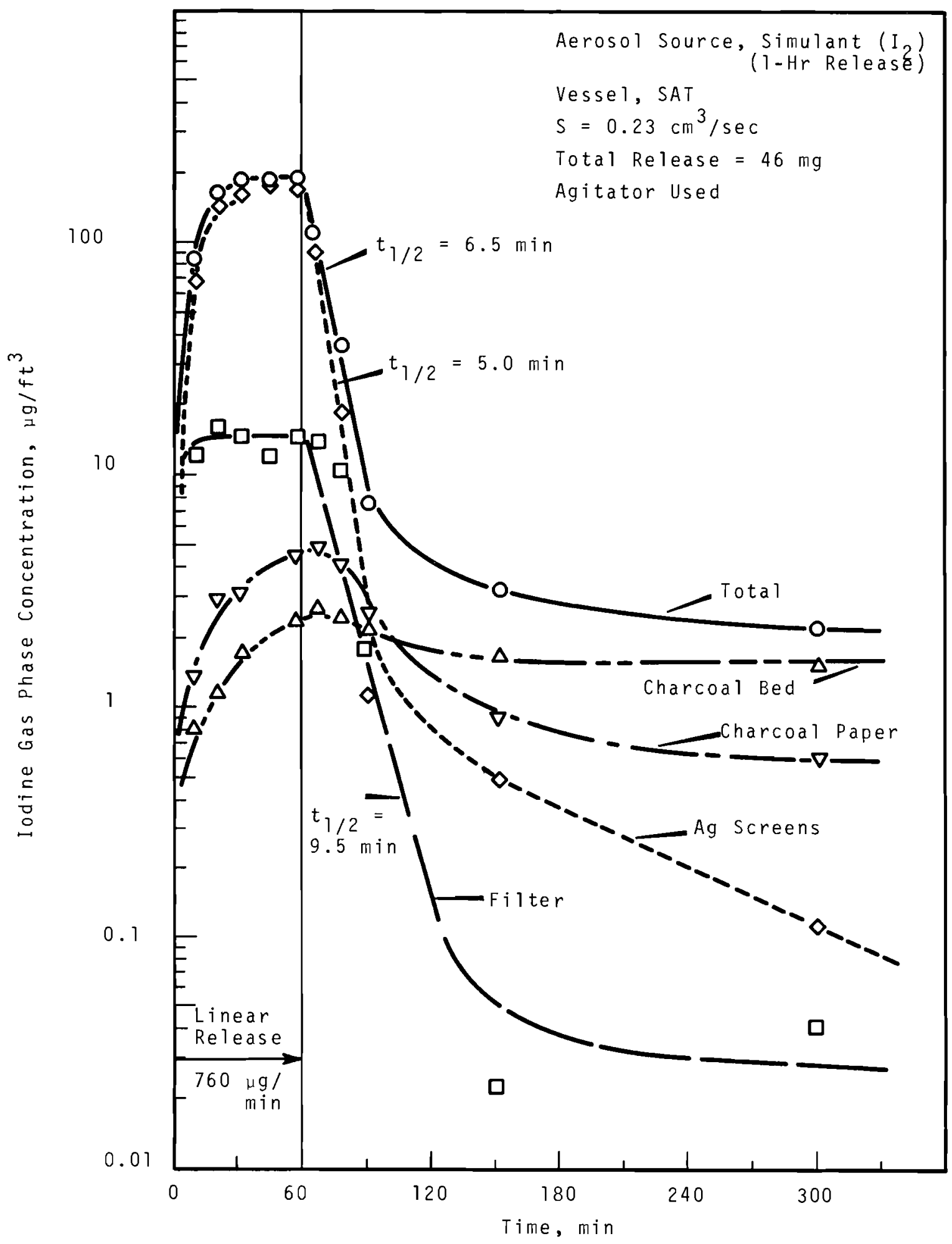

FIGURE B.20. Iodine Gas Phase Concentration, Run SB 74 


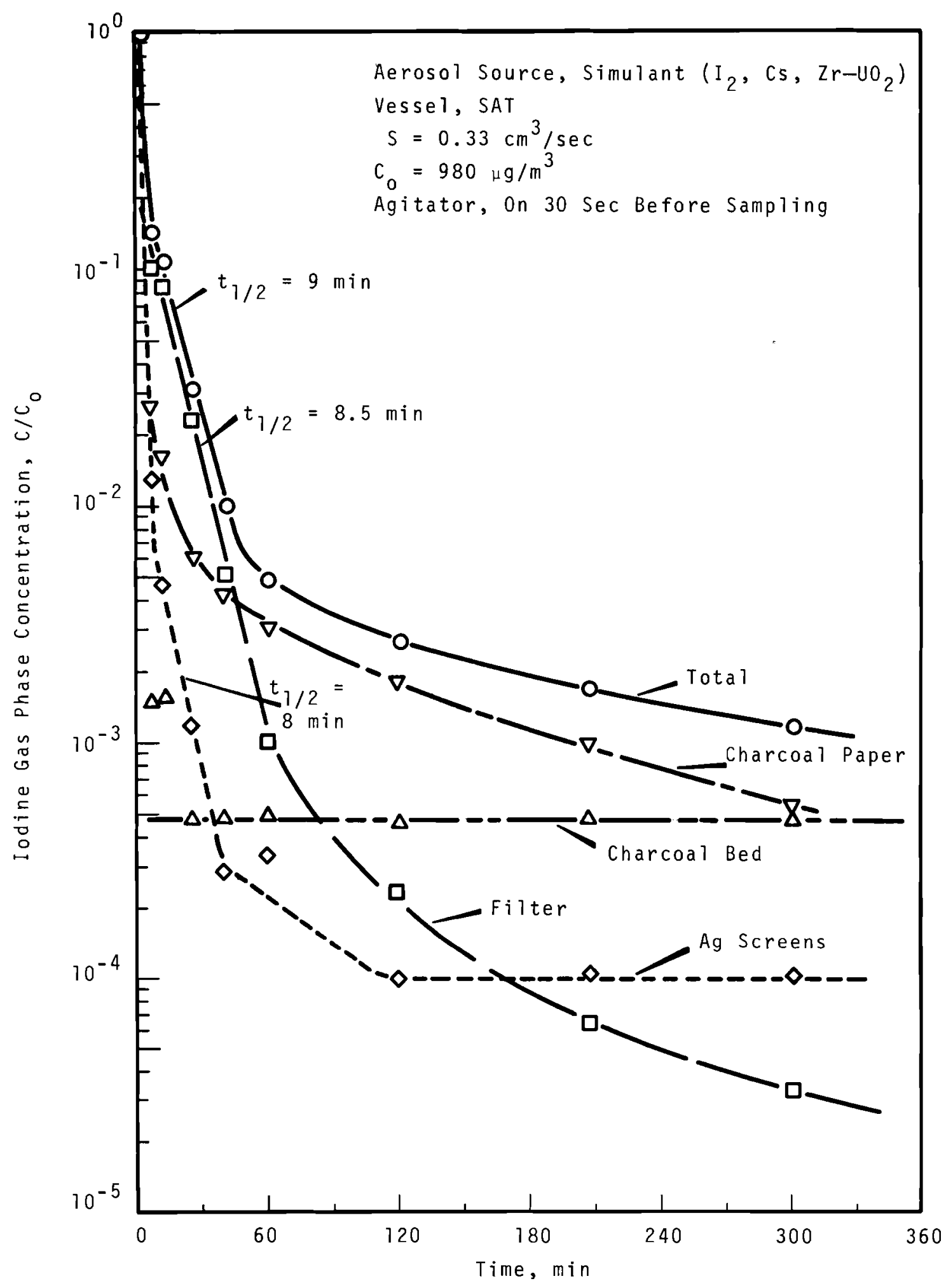

FIGURE B.21. Iodine Gas Phase Concentration, Run SB 78 


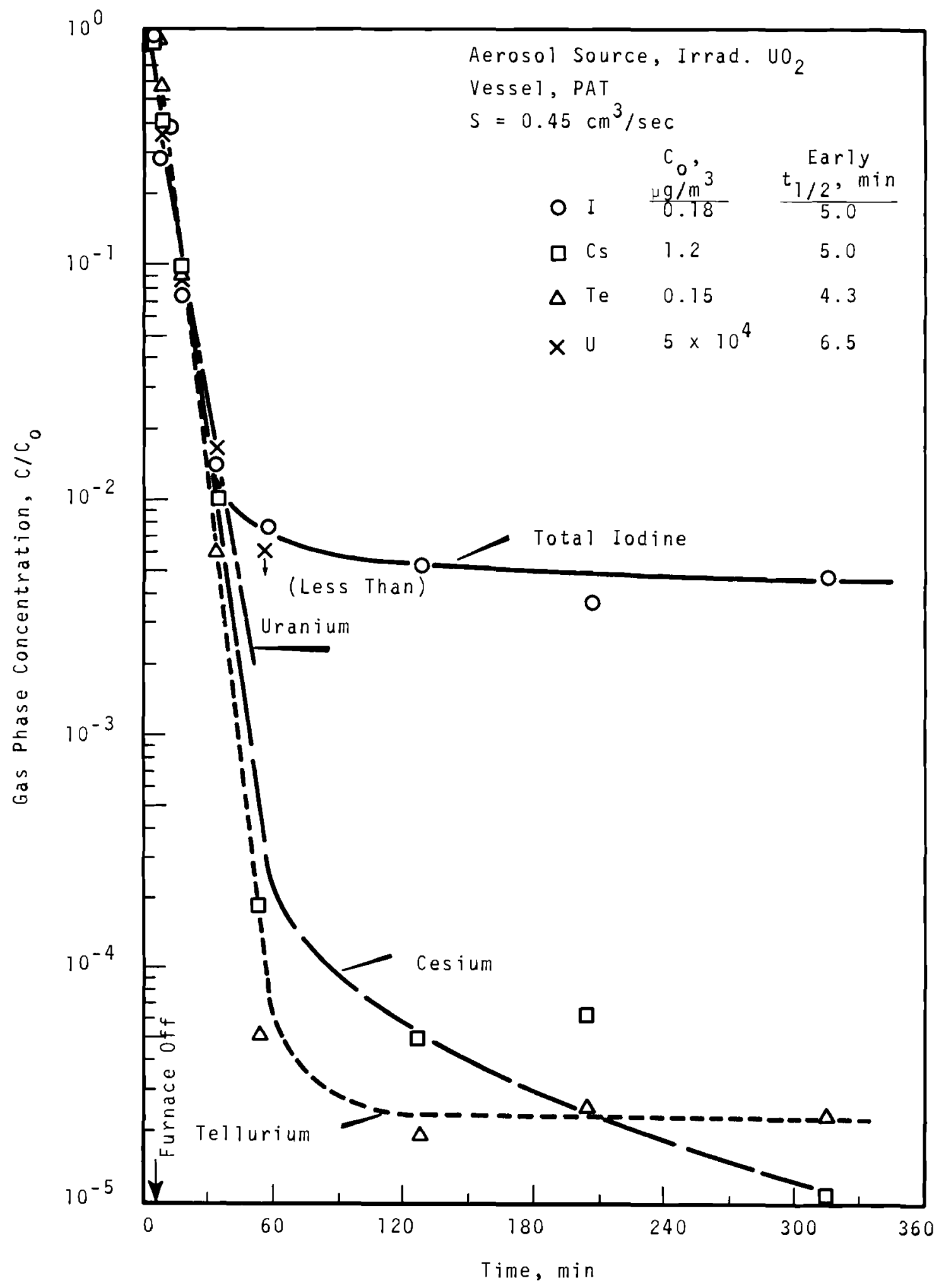

FIGURE B.22. Gas Phase Concentration, Run IA 32 


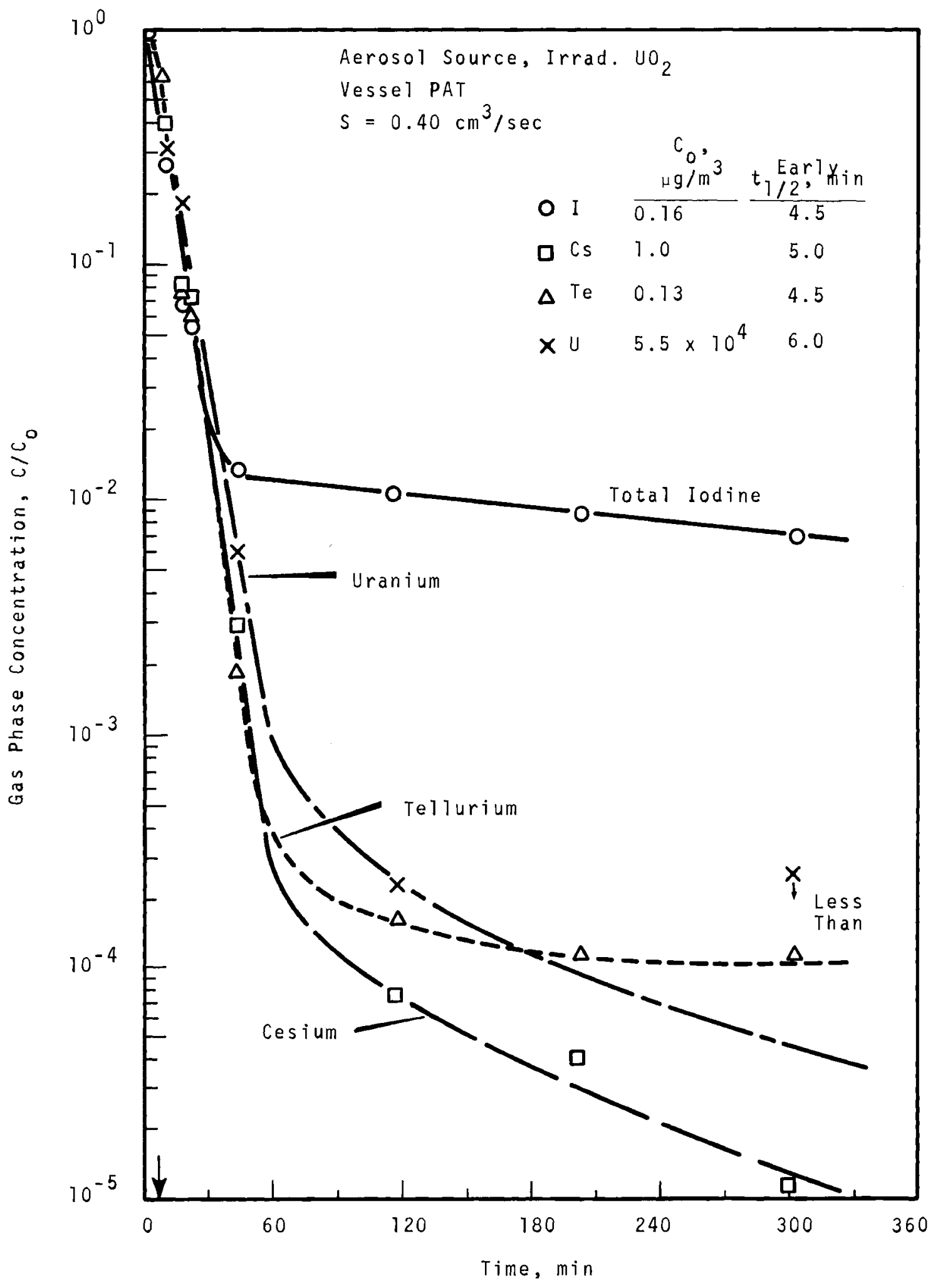

FIGURE B.23. Gas Phase Concentrations, Run IA 33 


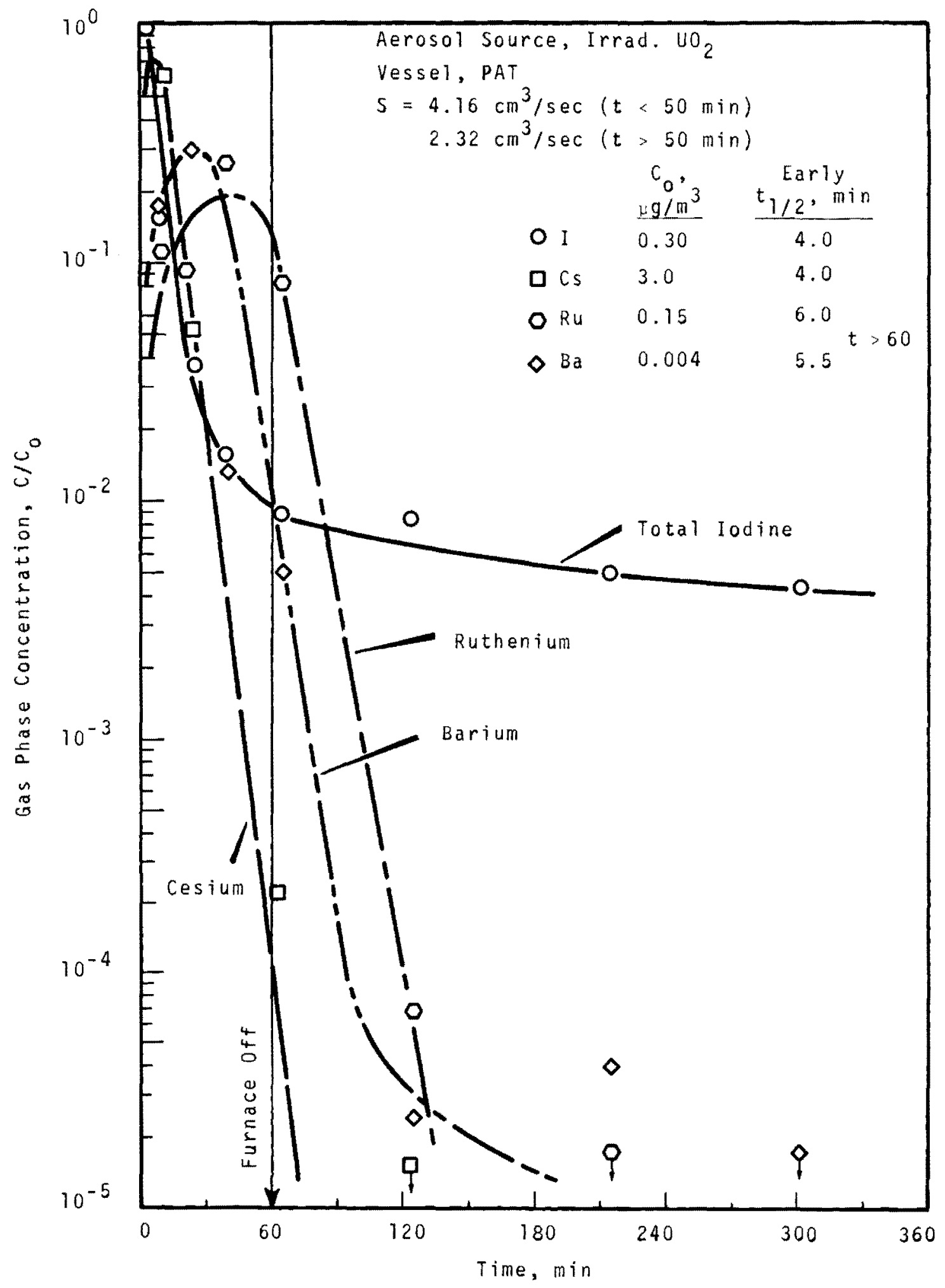

FIGURE B.24. Gas Phase Concentrations, Run IA 39 


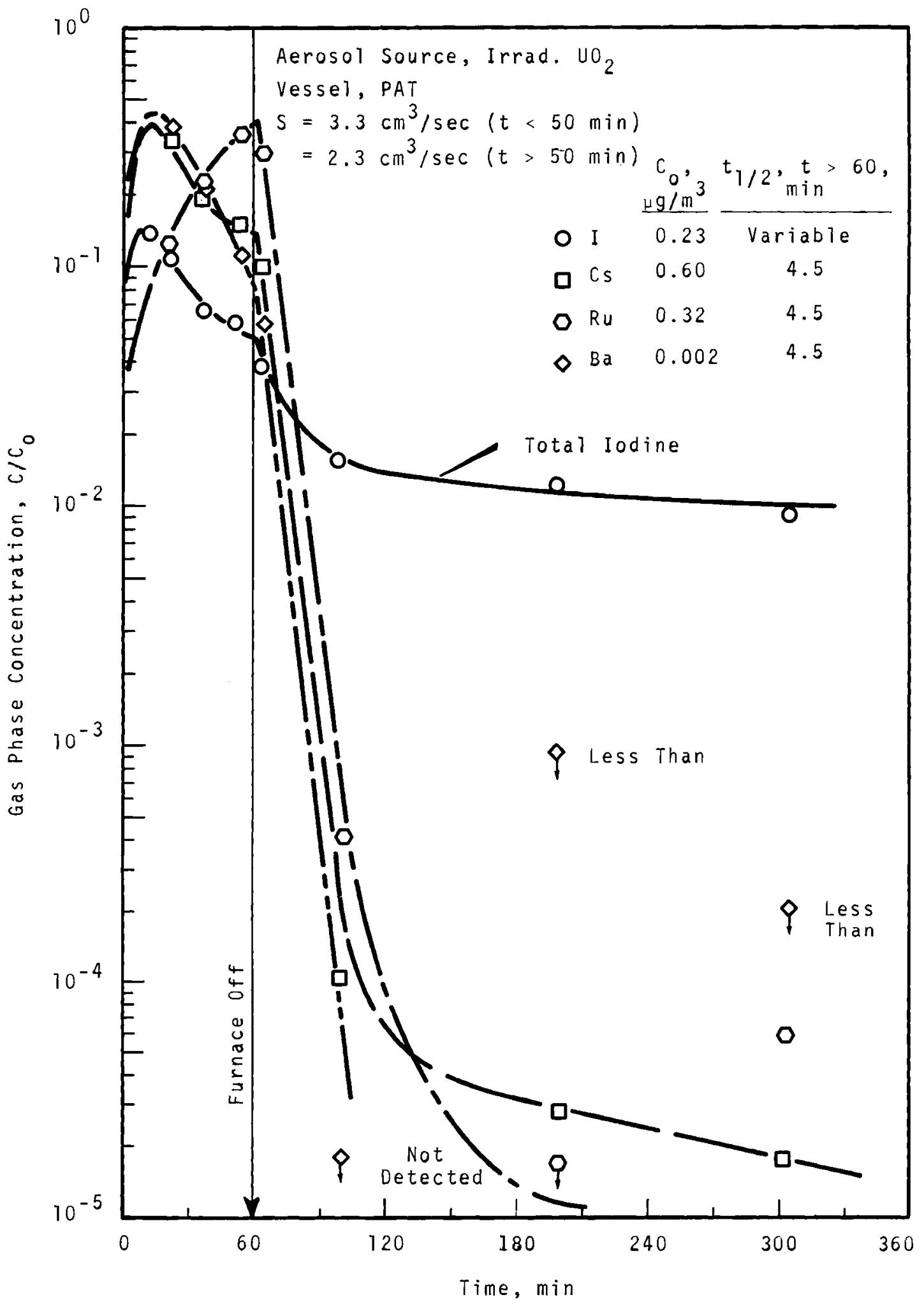

FIGURE B.25. Gas Phase Concentrations, Run IA 40 


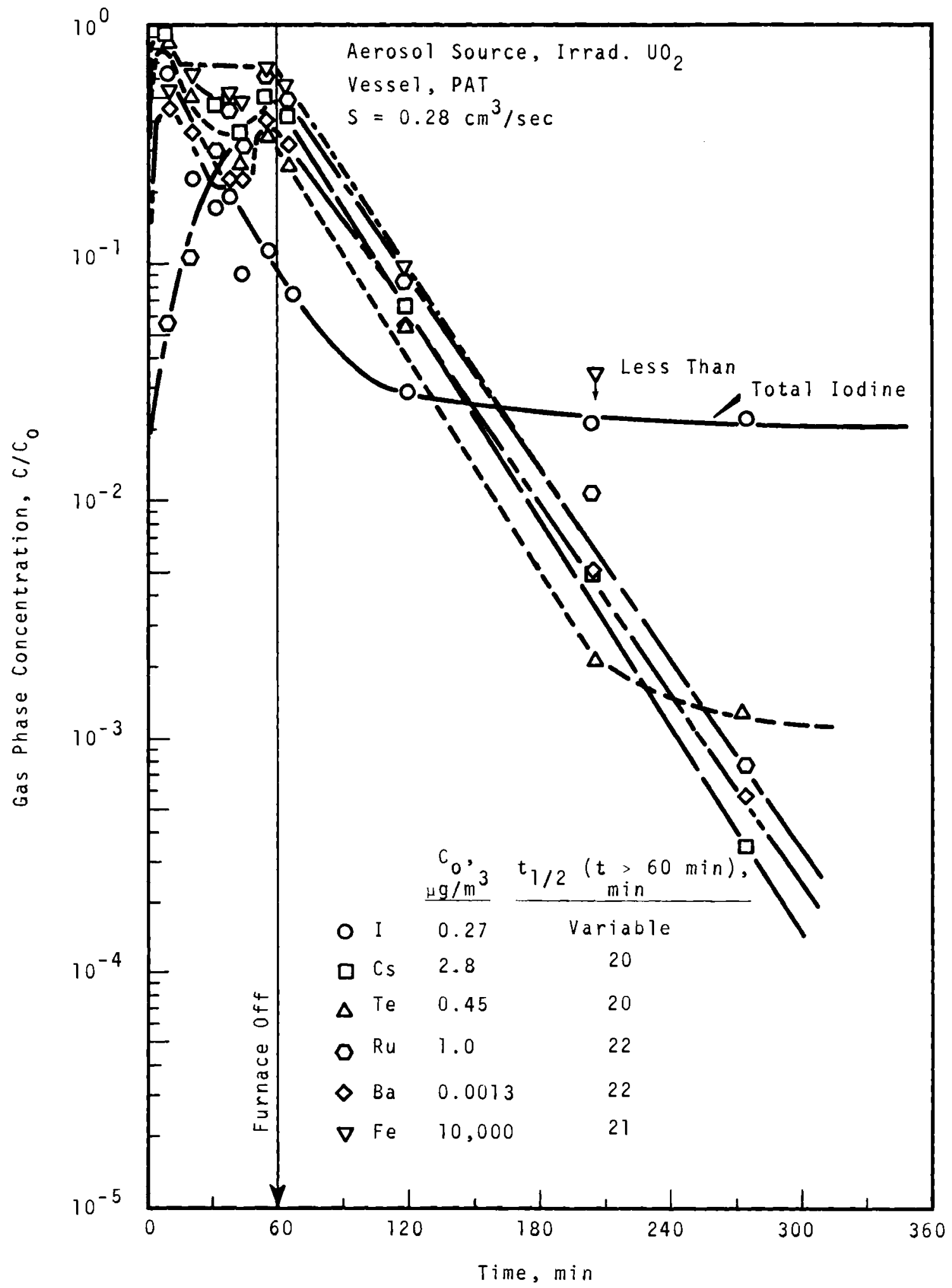

EIGURE B.26. Gas Phase Concentrations, Run IB 41 


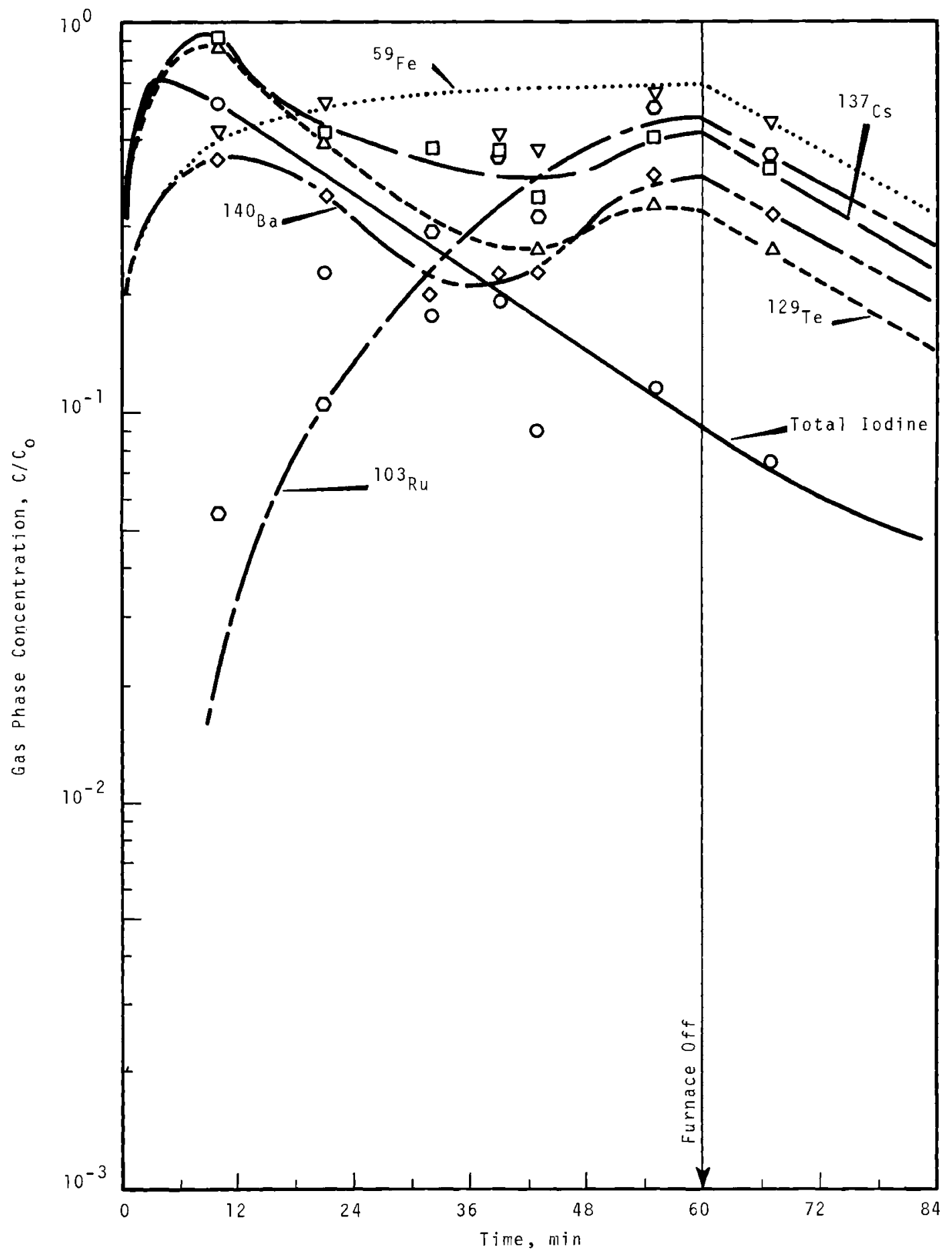

FIGURE B.27. Gas Phase Concentrations During the Release Period, Run IB 41 
B. 28

BNWL -581

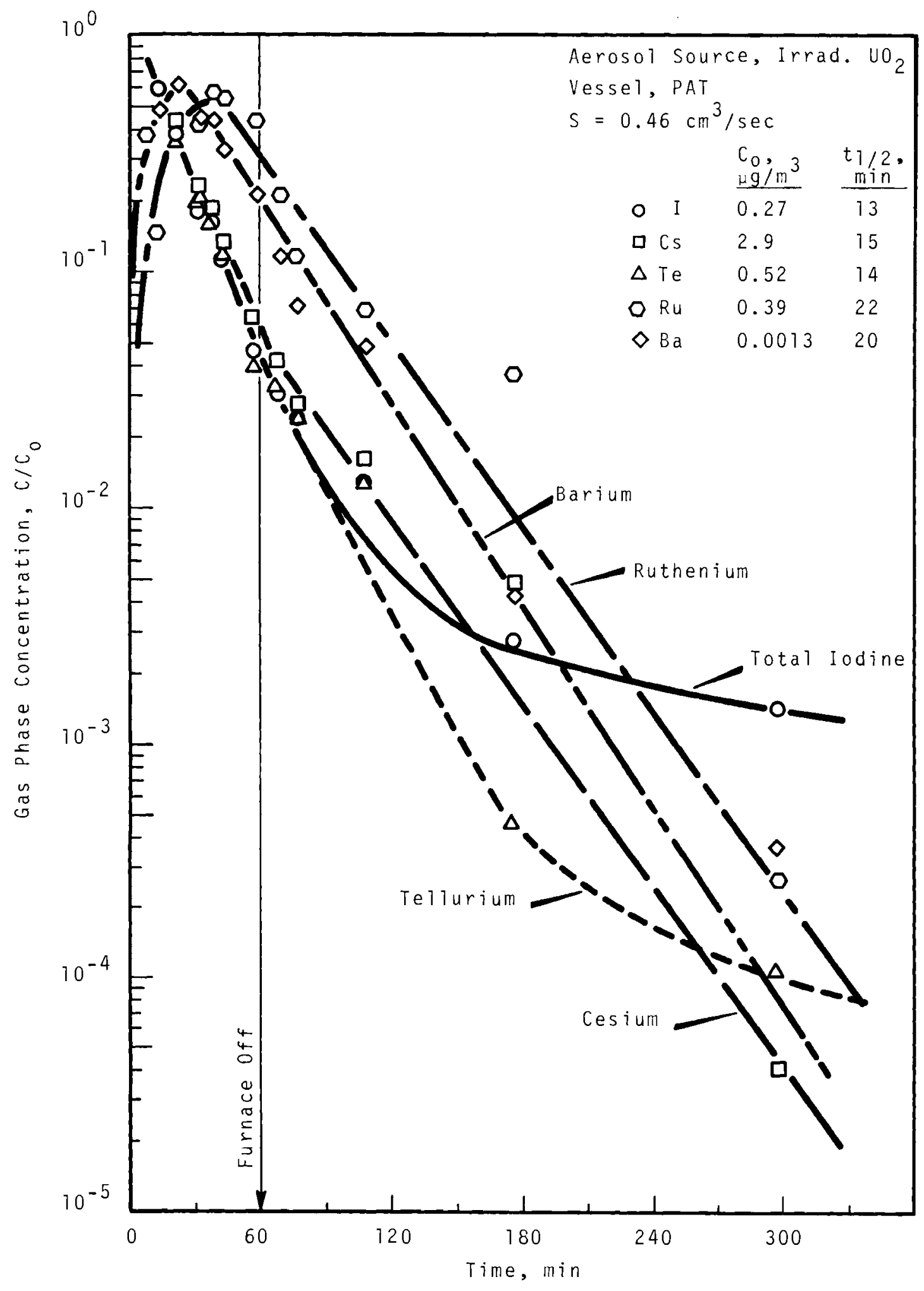

EIGURE B.28. Gas Phase Concentrations, Run IB 42 


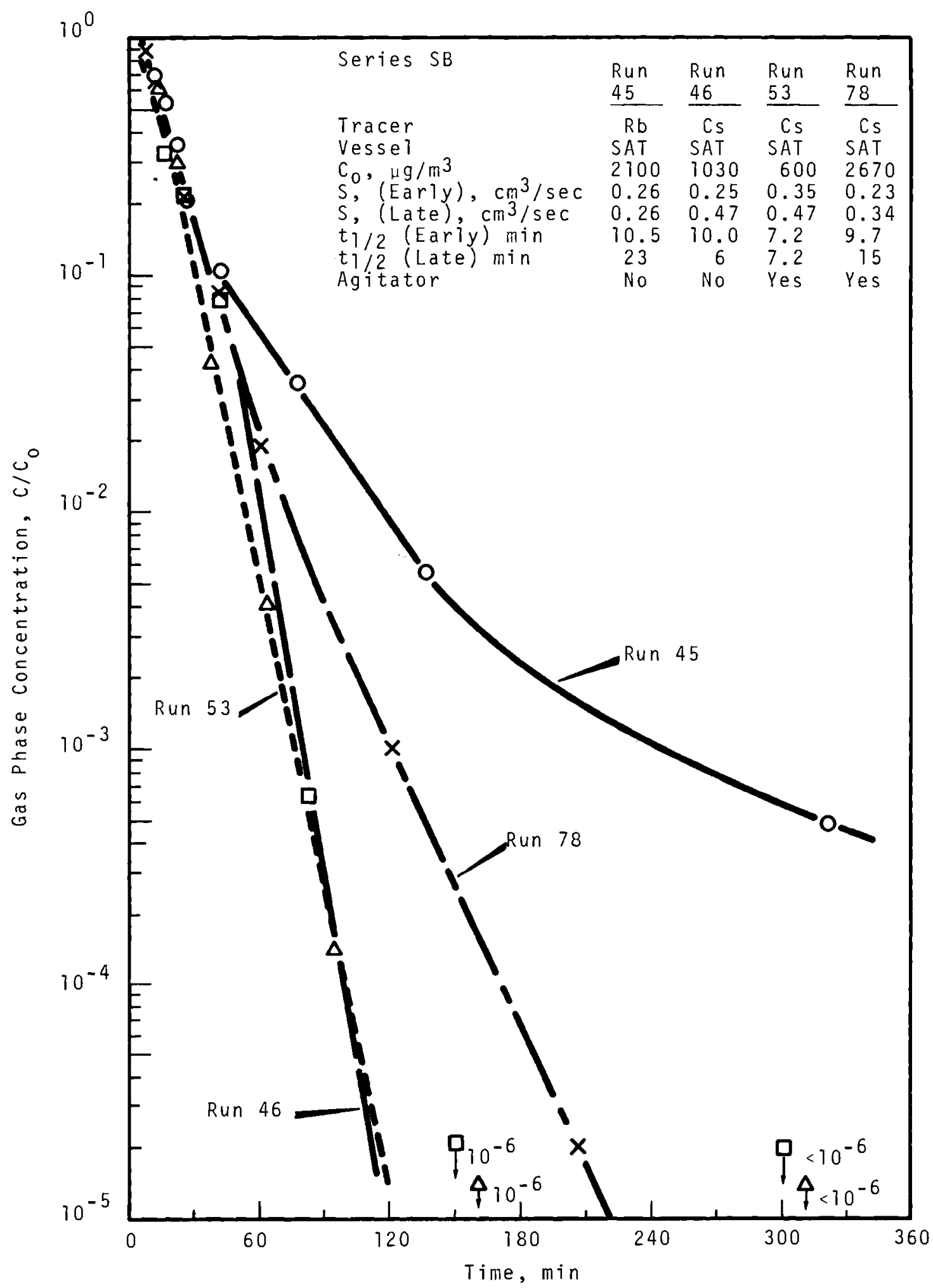

FIGURE B.29. Gas Phase Concentrations, Simulant Cesium 


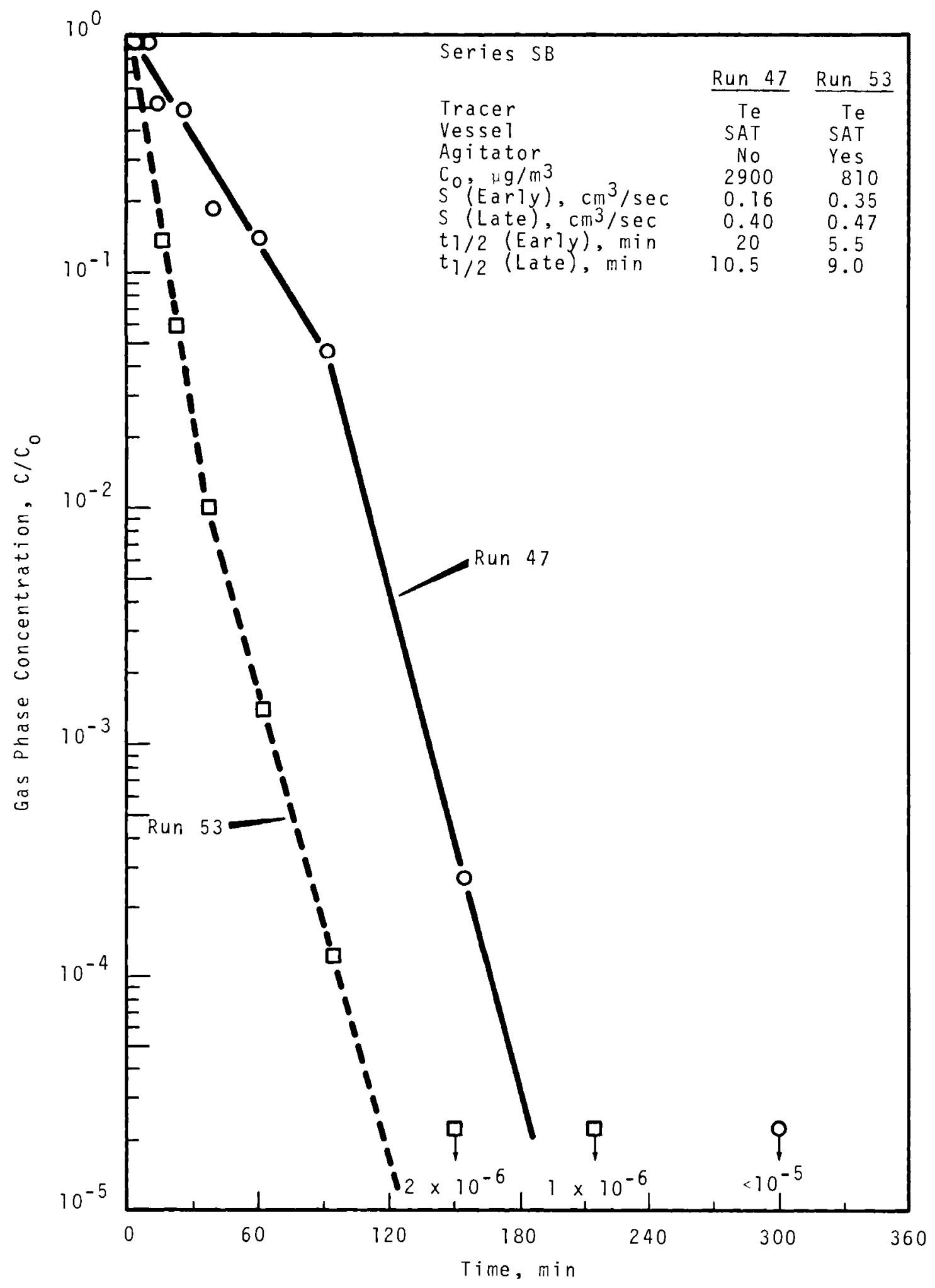

EIGURE B.30. Gas Phase Concentrations, Simulant Tellurium 


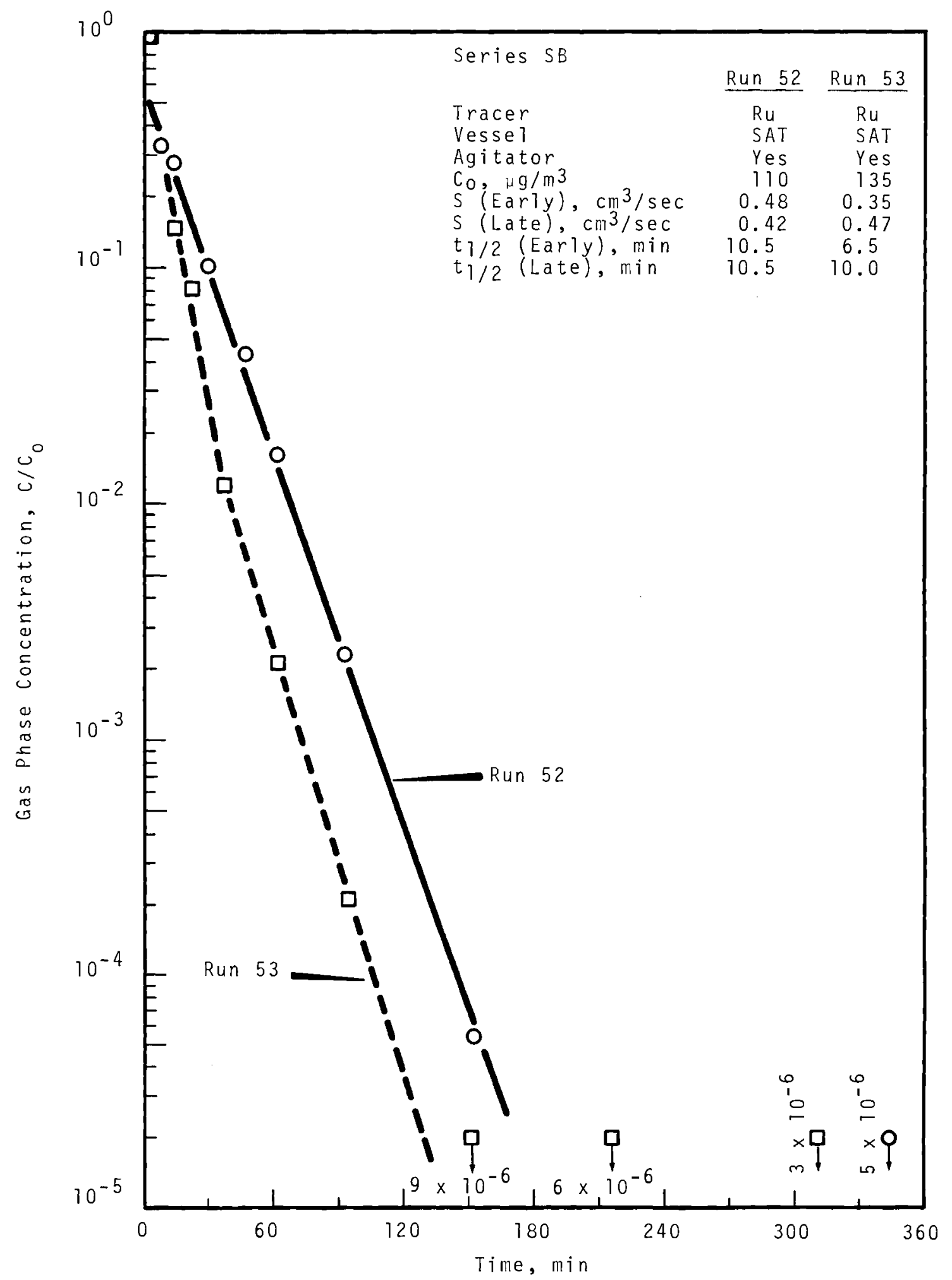

FIGURE B.31. Gas Phase Concentrations, Simulant Ruthenium 
B. 32

BNWL- 581

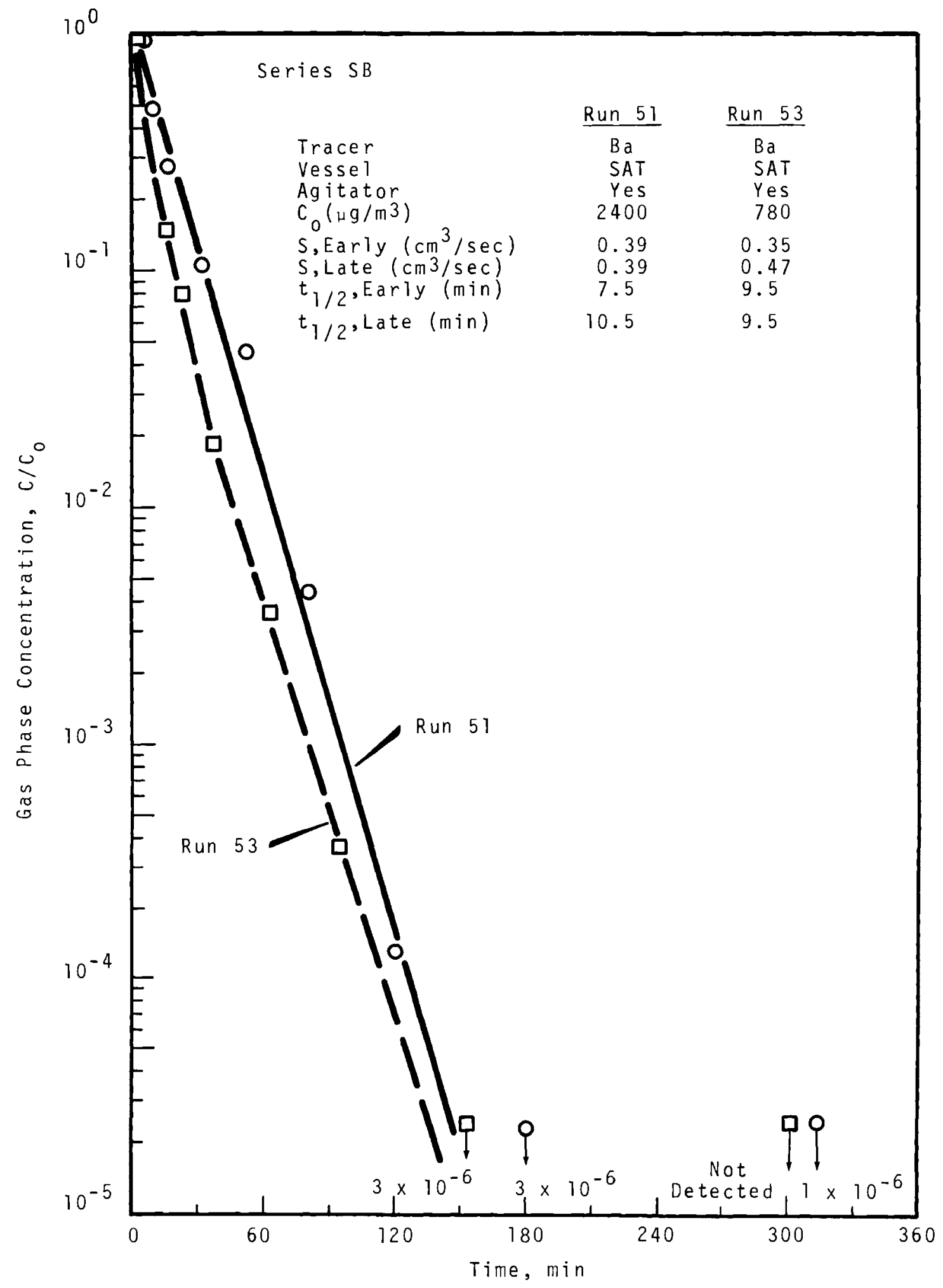

EIGURE B.32. Gas Phase Concentrations, Simuzant Barium 


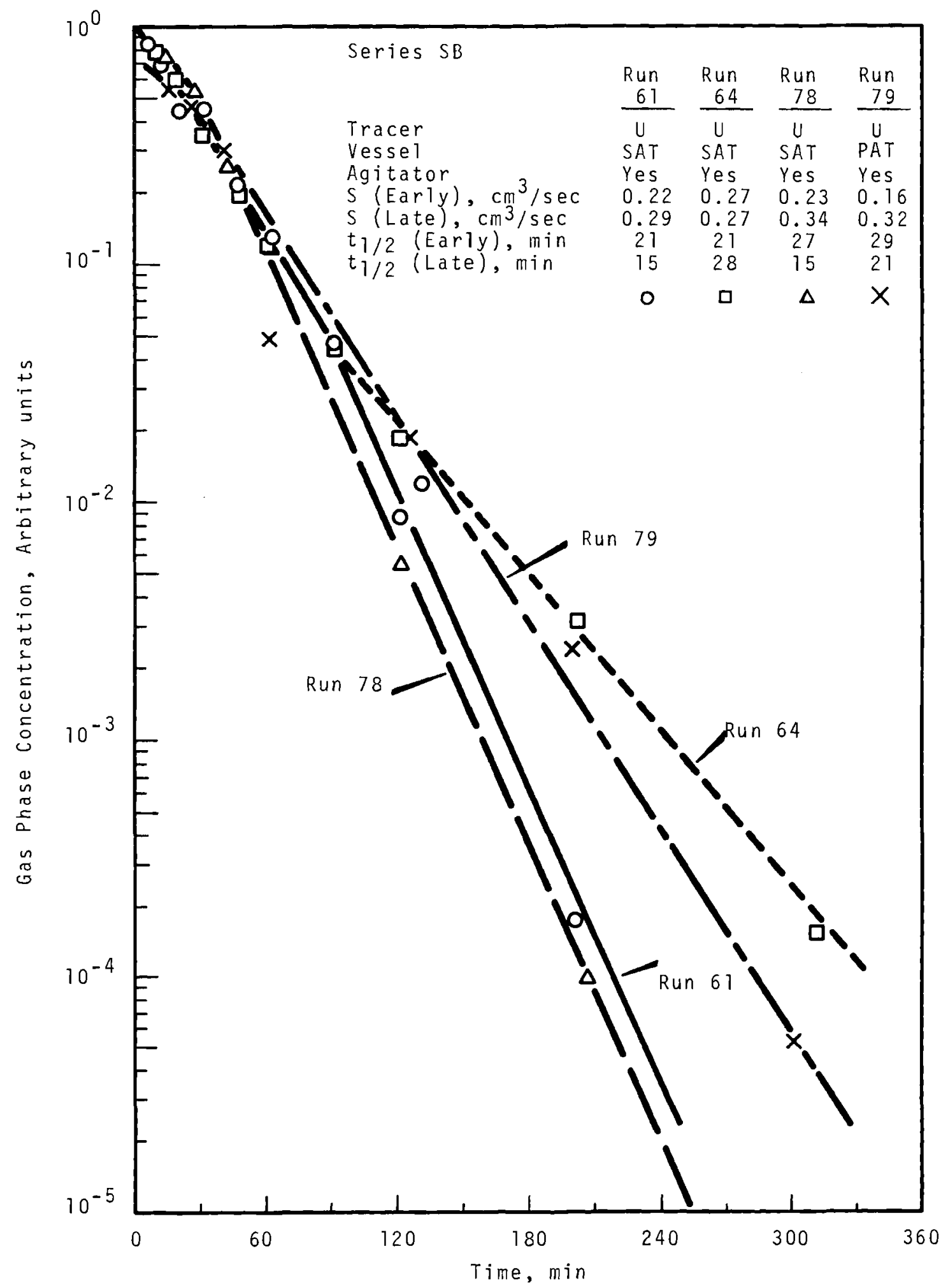

FIGURE B.33. Gas Phase Concentrations, Simulant Uranium 


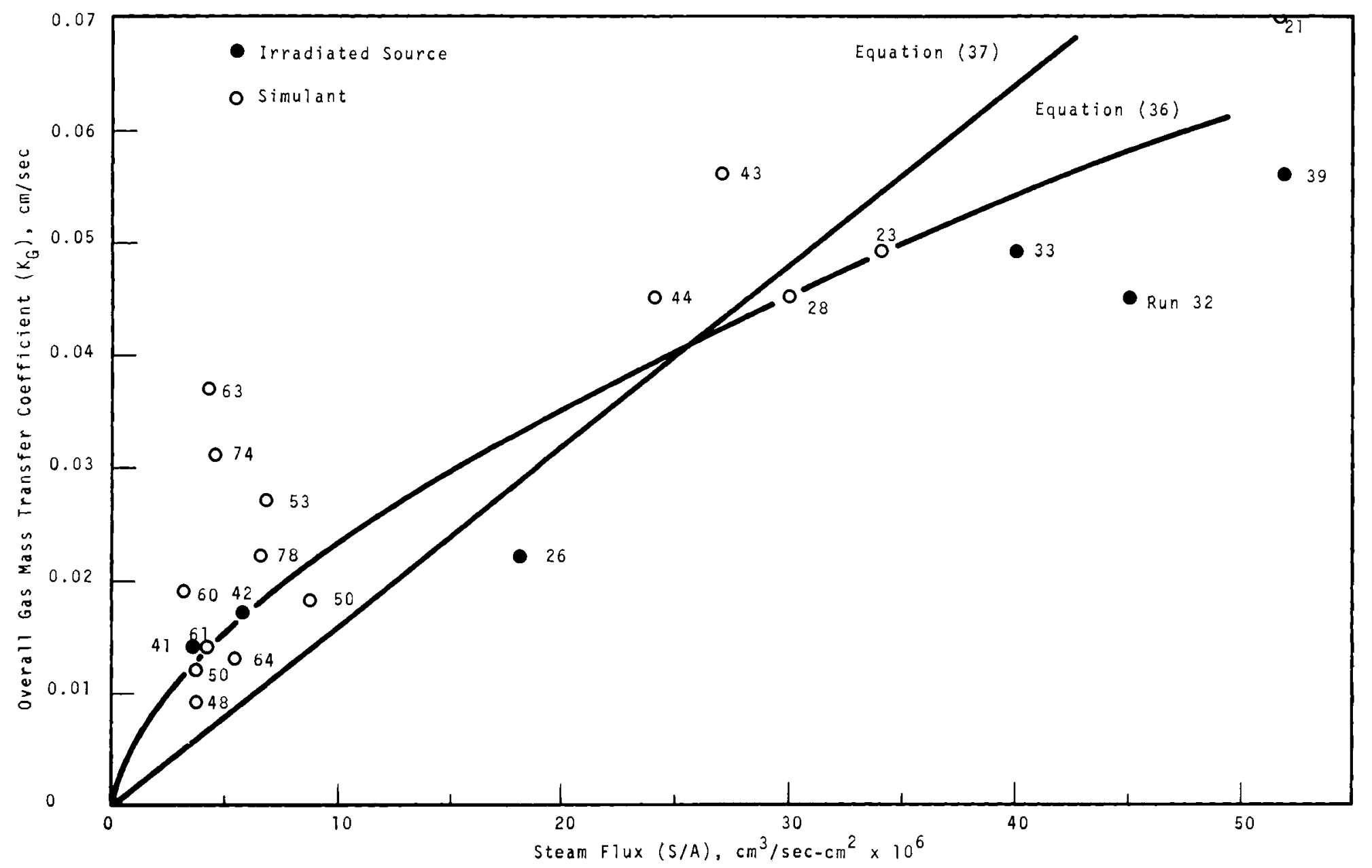

$\underset{\perp}{\varpi}$

FIGURE B.34. Mass Transfer Coefficient Versus Steam Flux, Total Iodine 


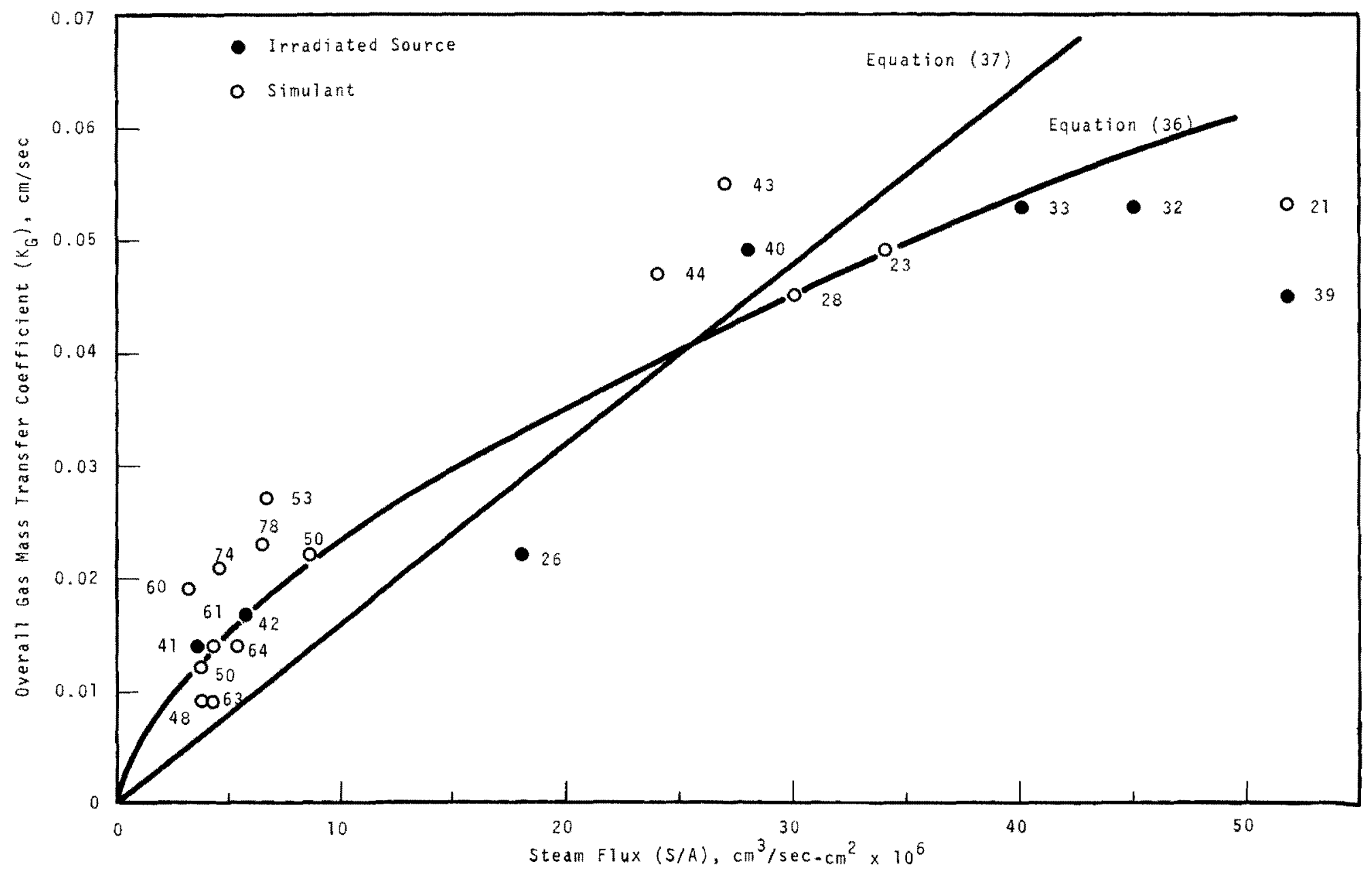

FIGURE B.35. Mass Transfer Coefficient Versus Steam Flux, Particulate Iodine 


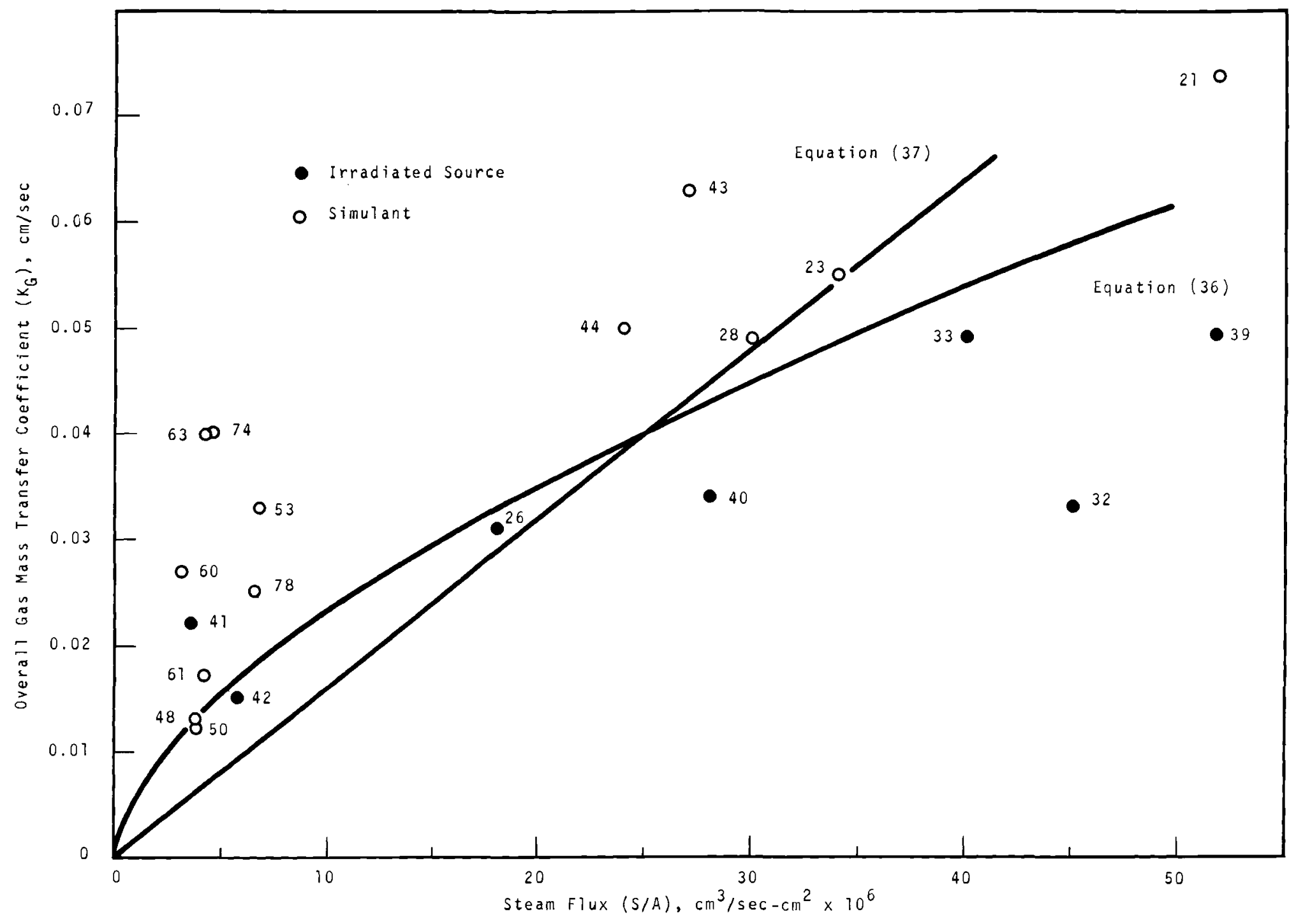

EIGURE B.36. Mass Transfer Coefficient Versus Steam Flux, E'Zemental Iodine 


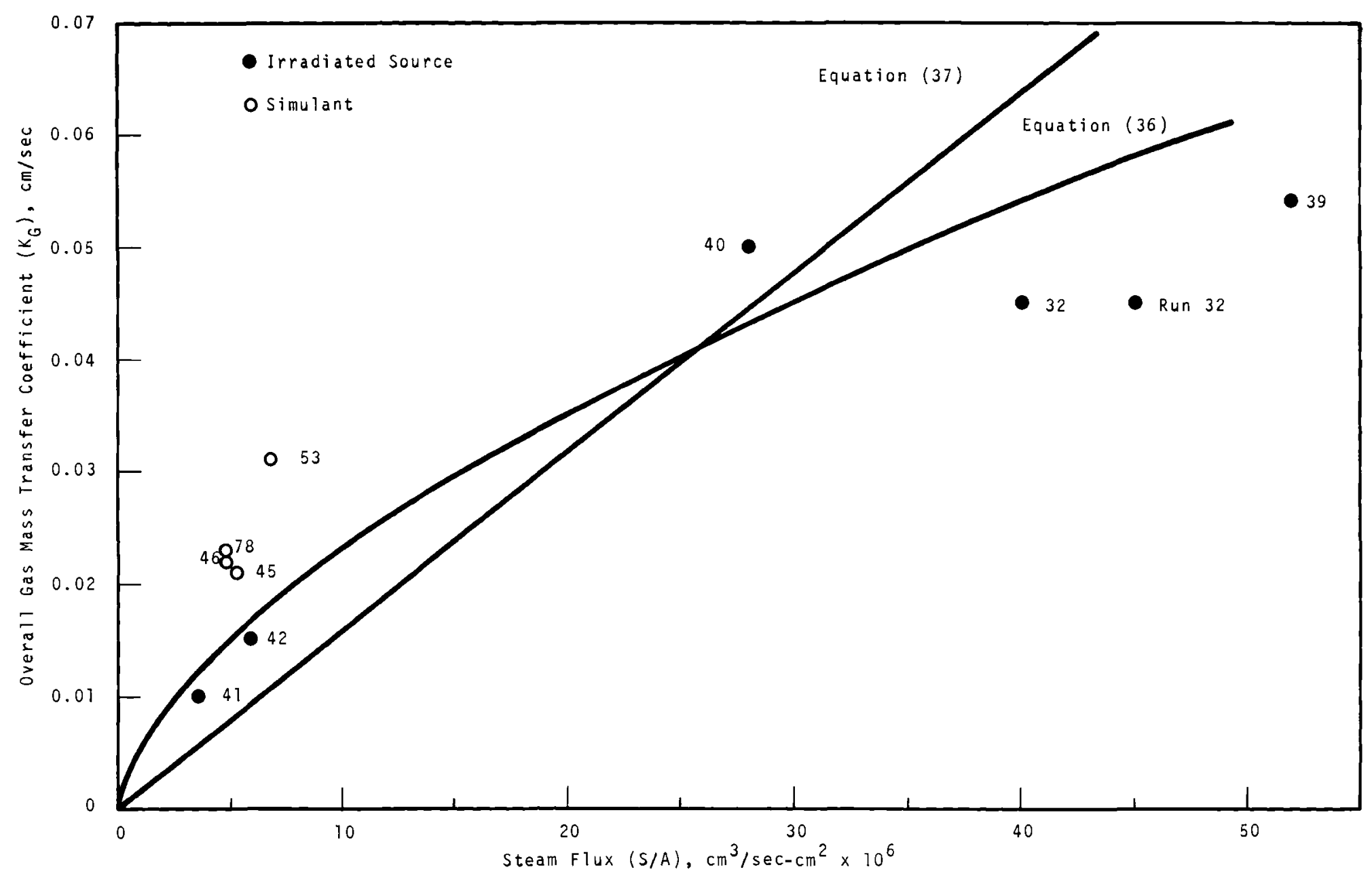

EIGURE B.37. Mass Transfer Coefficient Versus Steam Flux, Cesium 


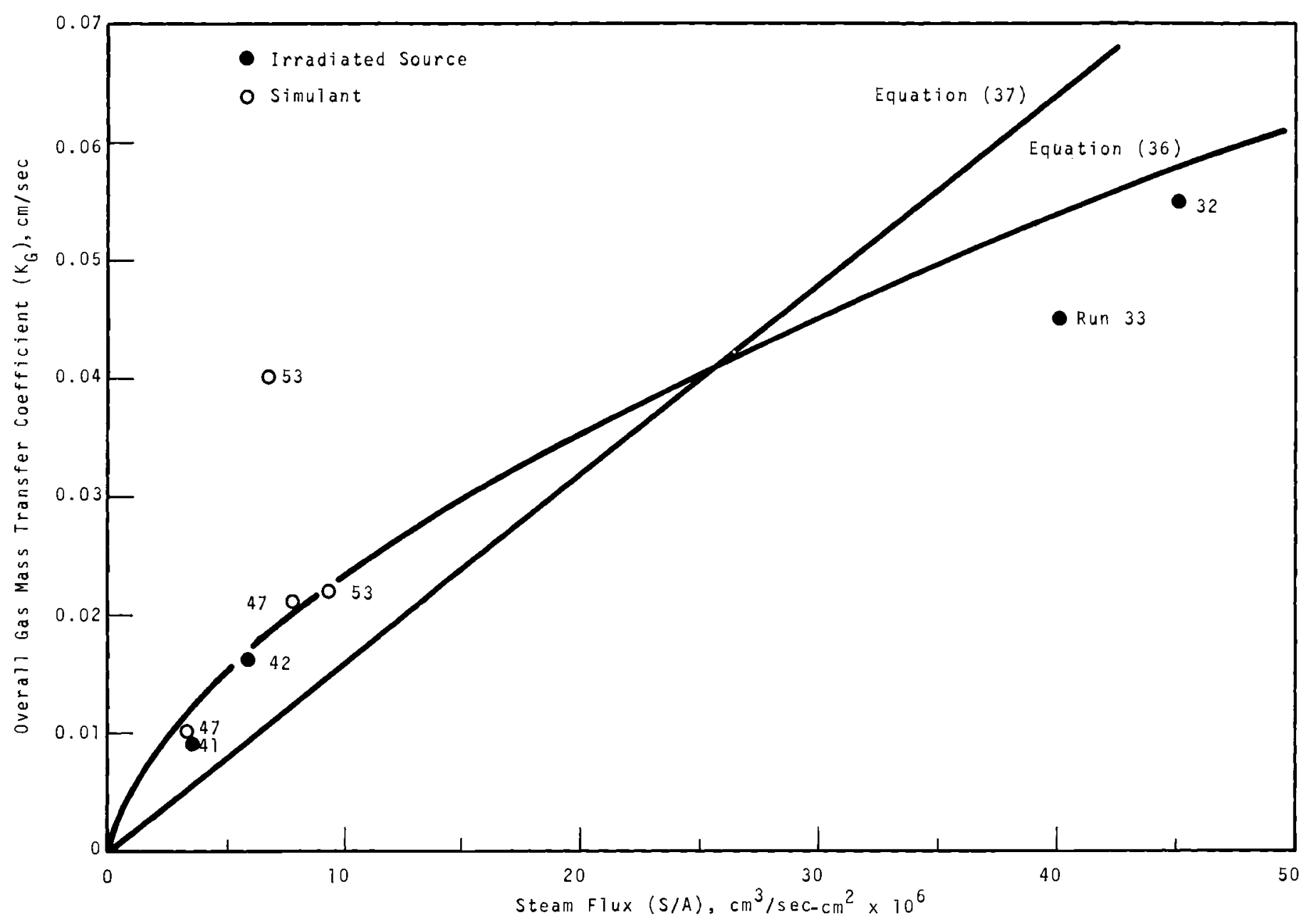

EIGURE B.38. Mass Transfer Coefficients Versus Steam Flux, TeZZurium 


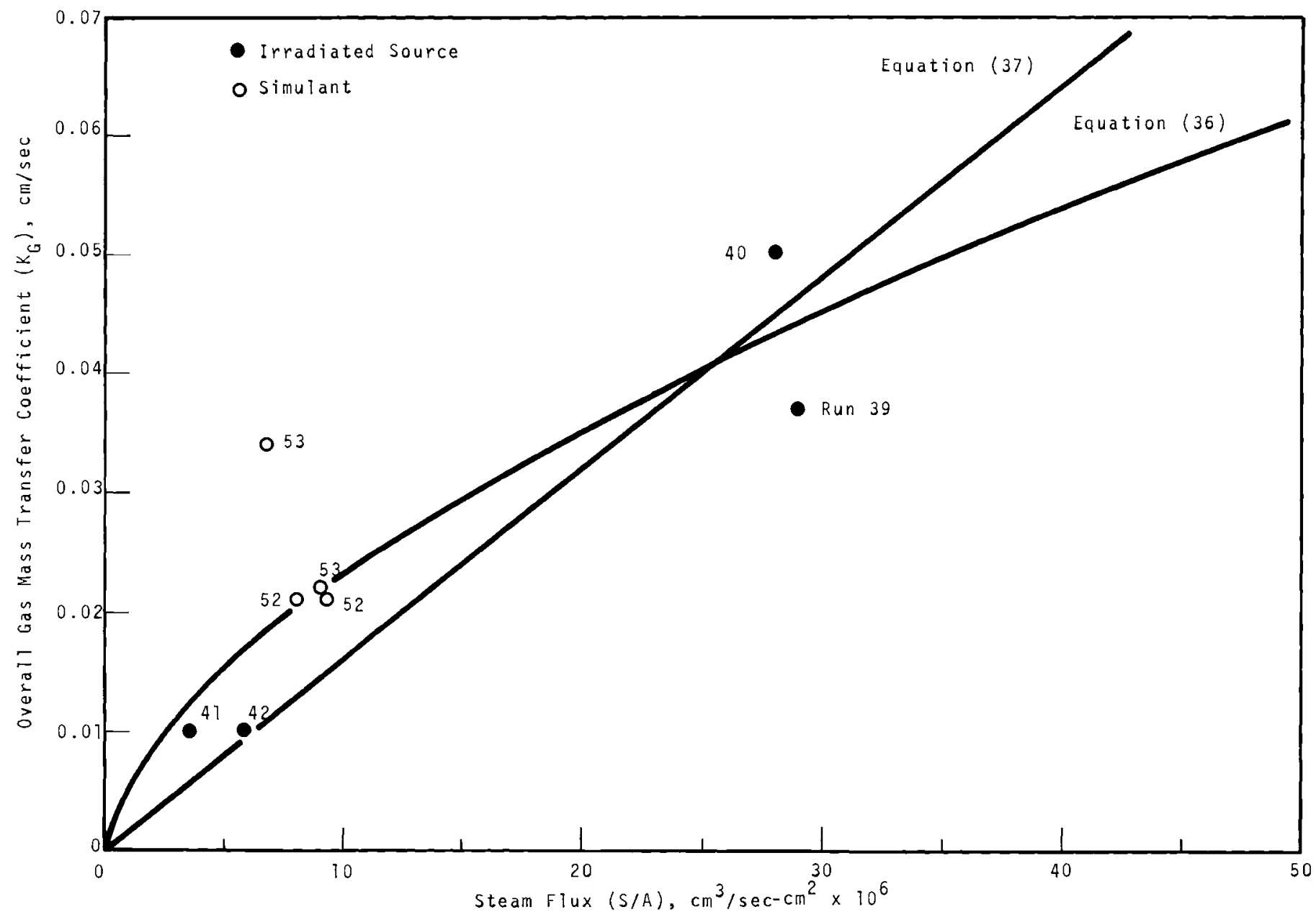

FIGURE B.39. Mass Transfer Coefficient Versus Steam Flux, Ruthenium 


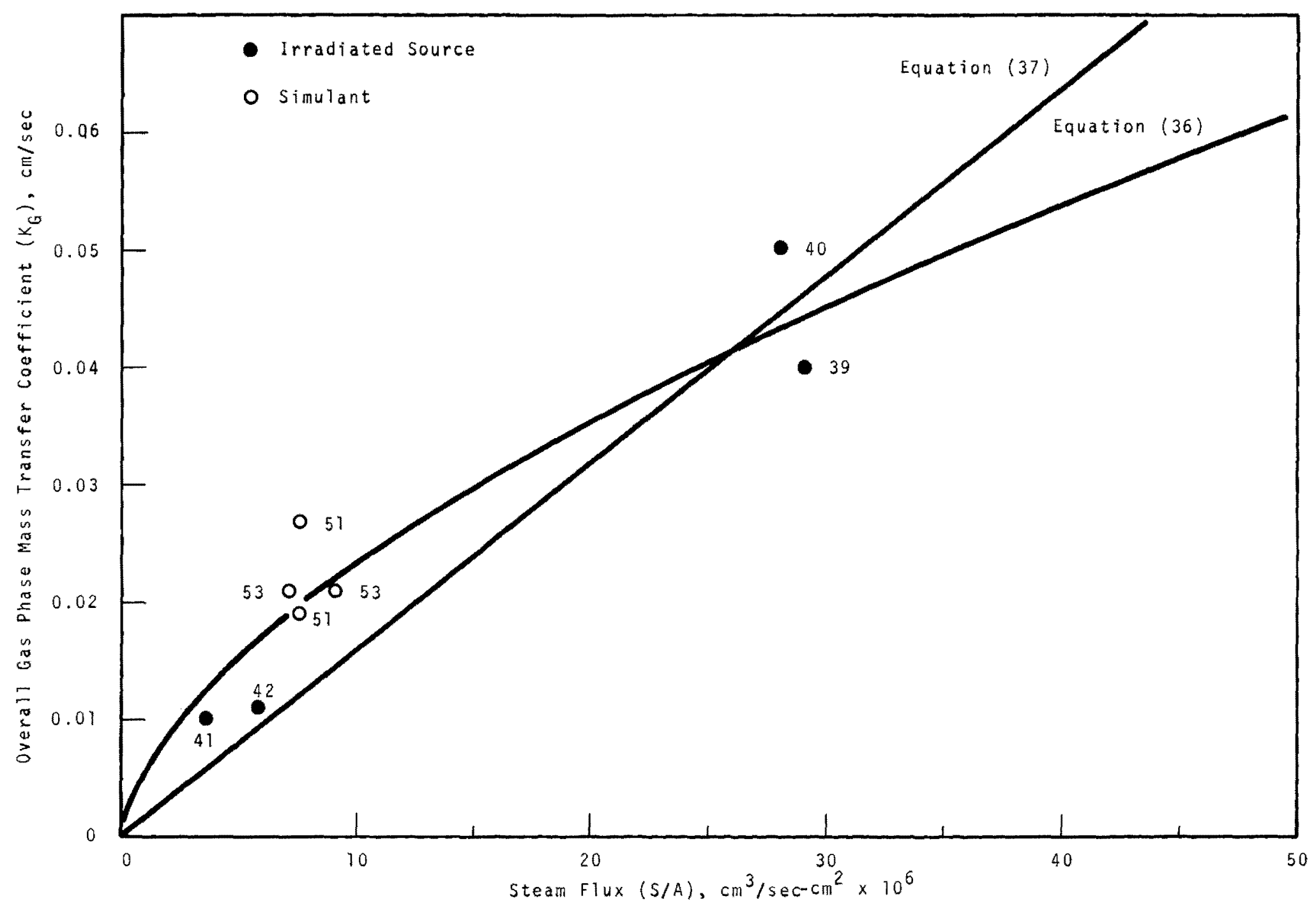

$\infty$
0
0

品

FIGURE B.40. Mass Transfer Coefficient Versus Steam Flux, Barium 


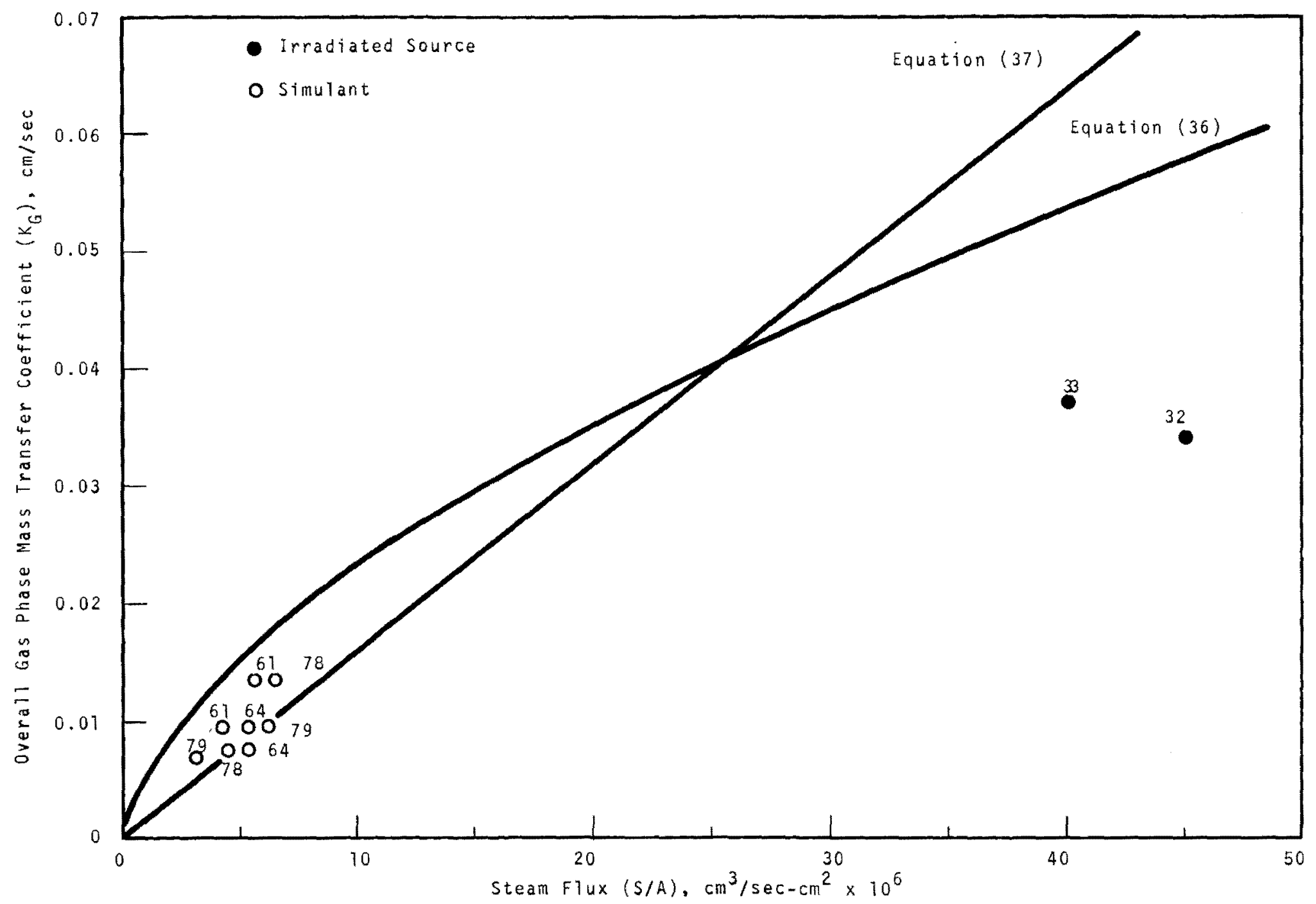

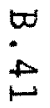

EIGURE B.41. Mass Transfer Coefficient Versus Steam Flux, Uranium 


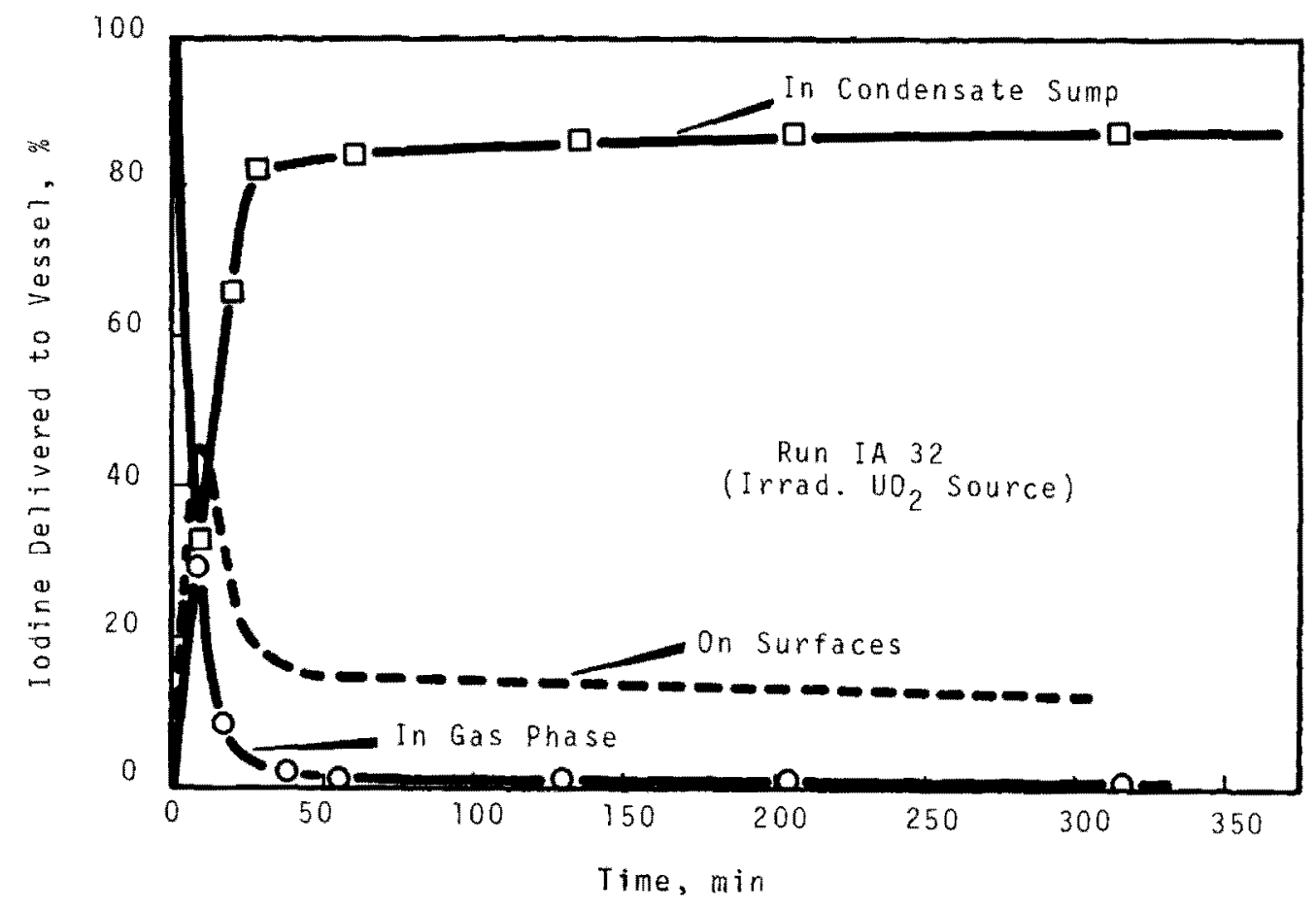

EIGURE B.42. Iodine Distribution, Series IA

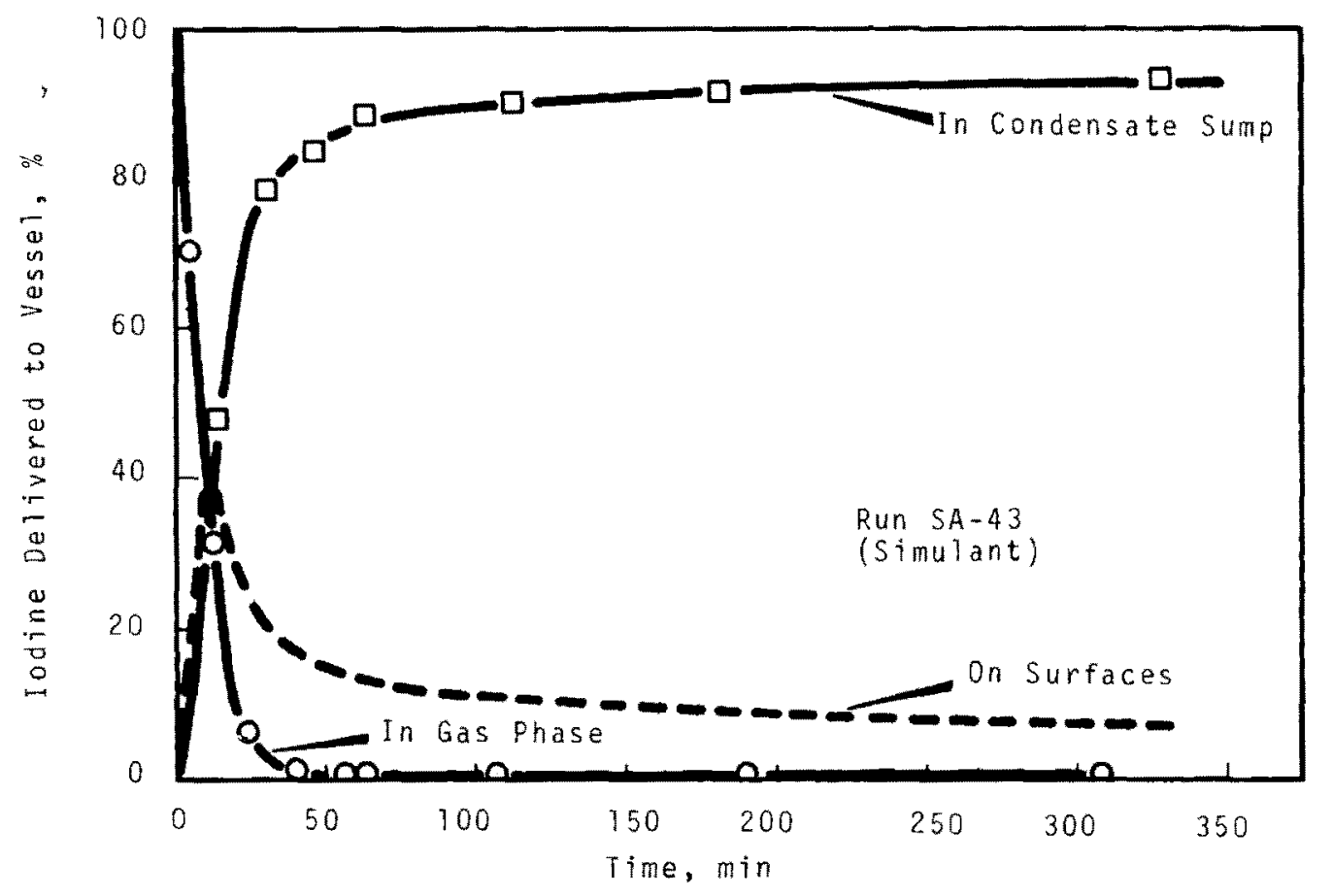

EIGURE B.43. Iodine Distribution, Series $S A$ 
B. 43

BNWL - 581

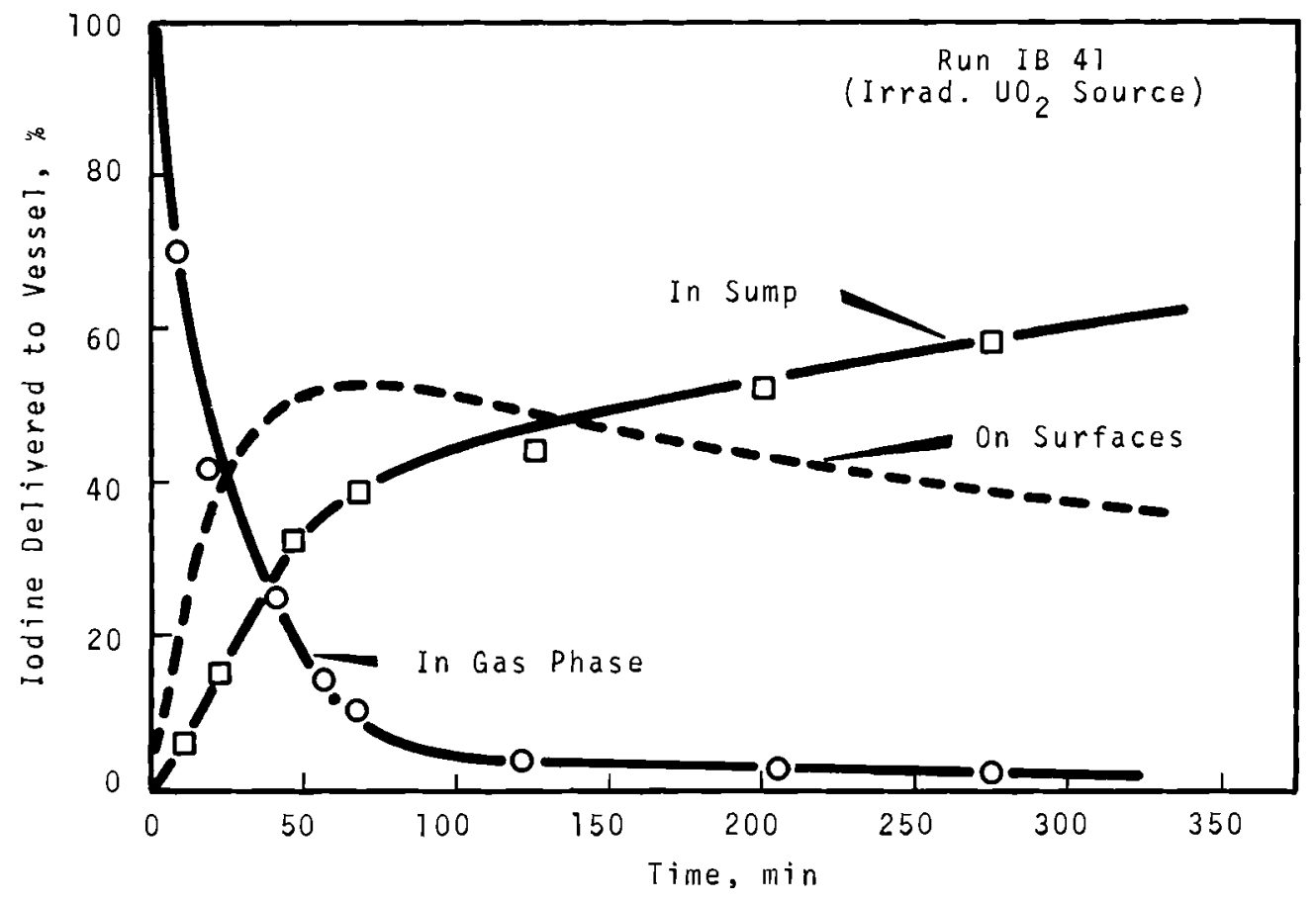

FIGURE B.44. Iodine Distribution, Series IB

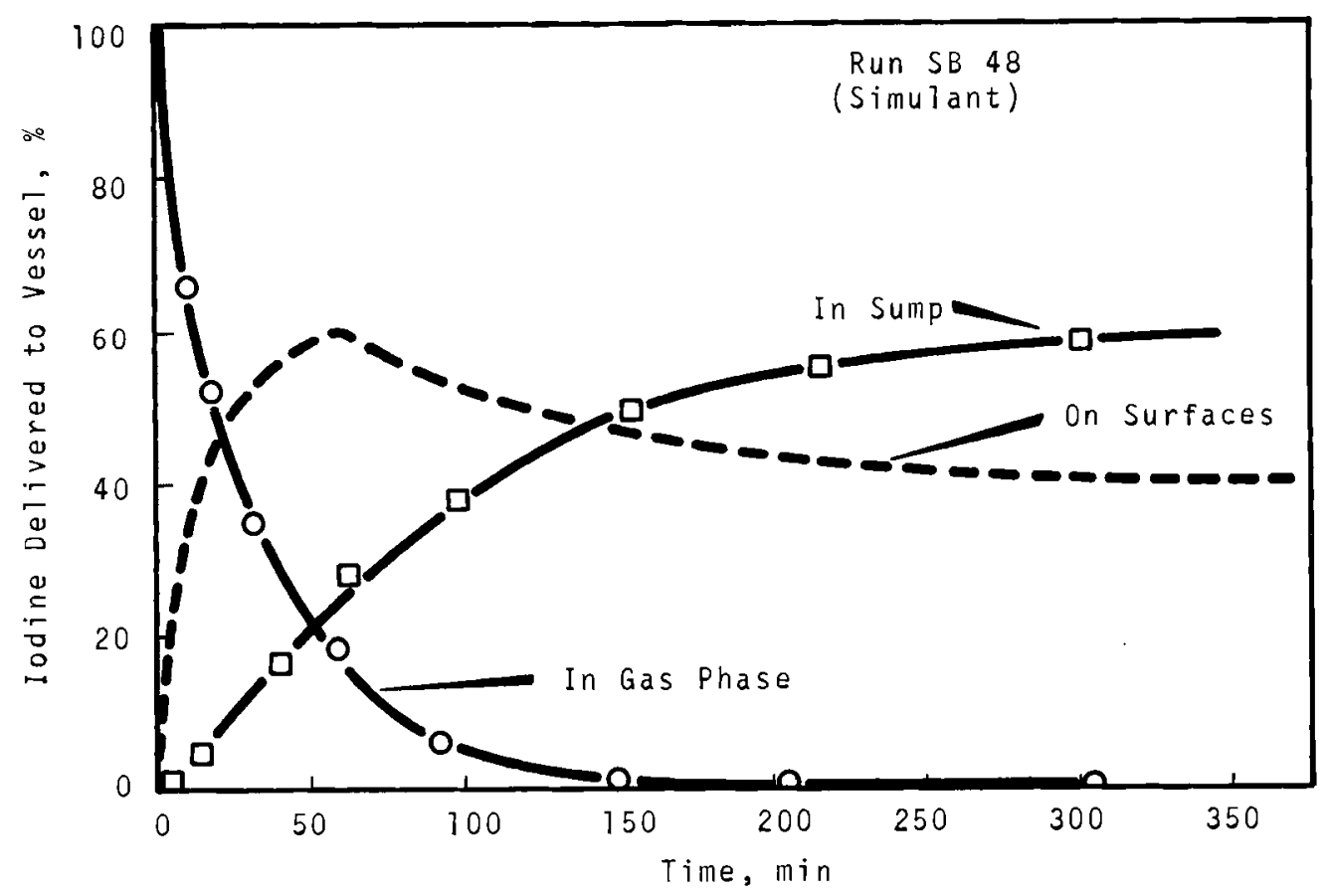

FIGURE B.45. Iodine Distribution, Series SB 


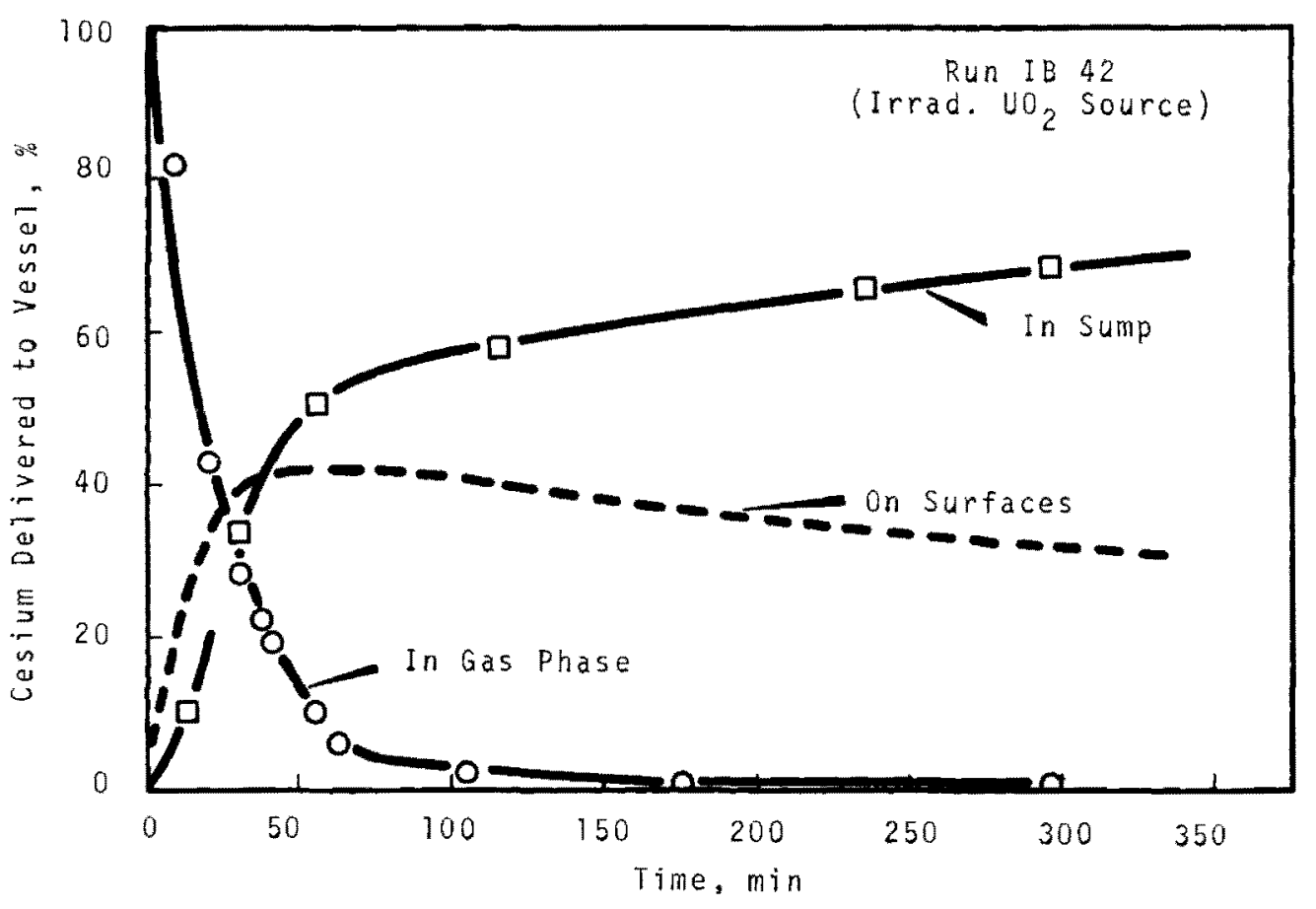

EIGURE B.46. Cesium Distribution, Series IB

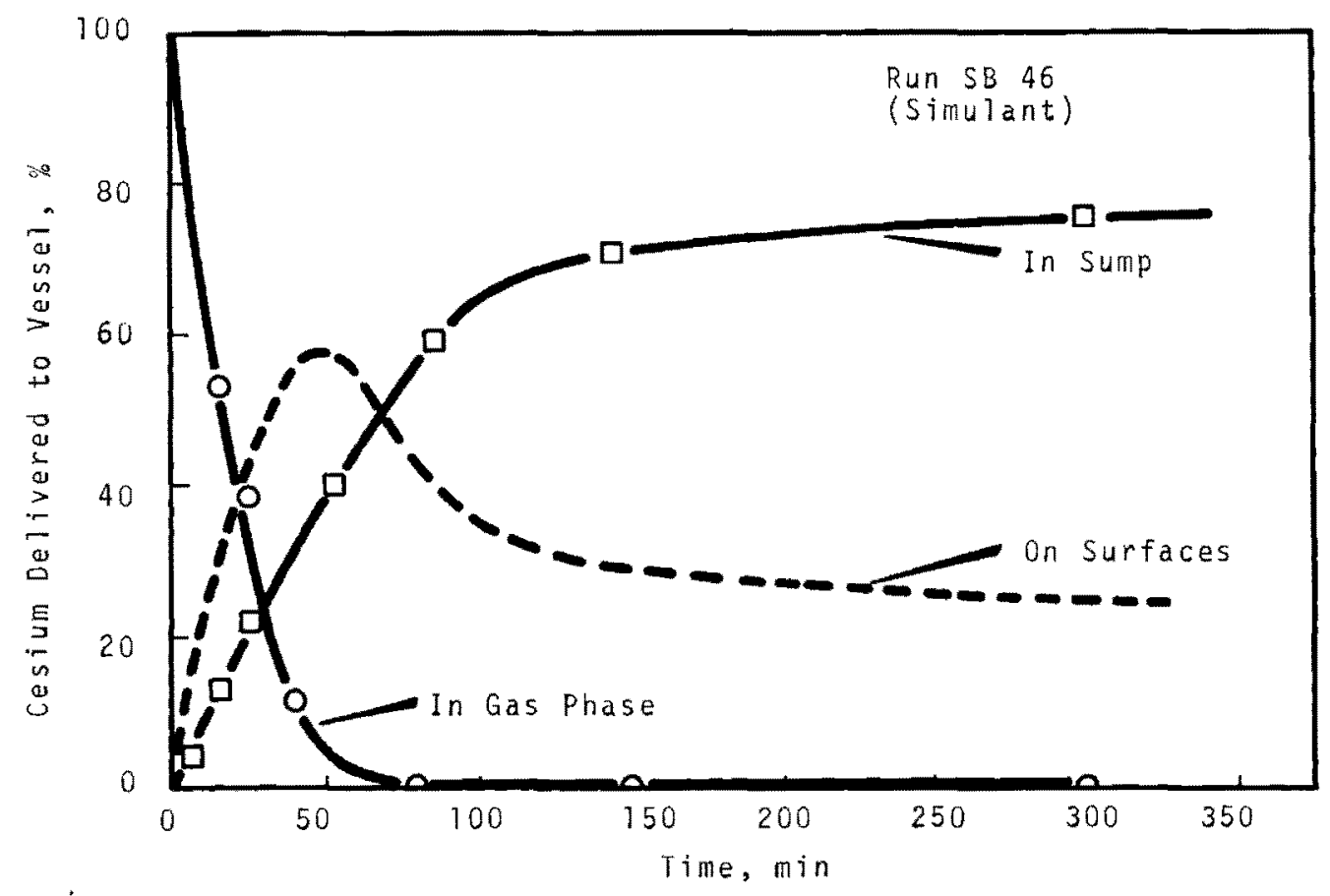

EIGURE B.47. Cesium Distribution, Series SB 


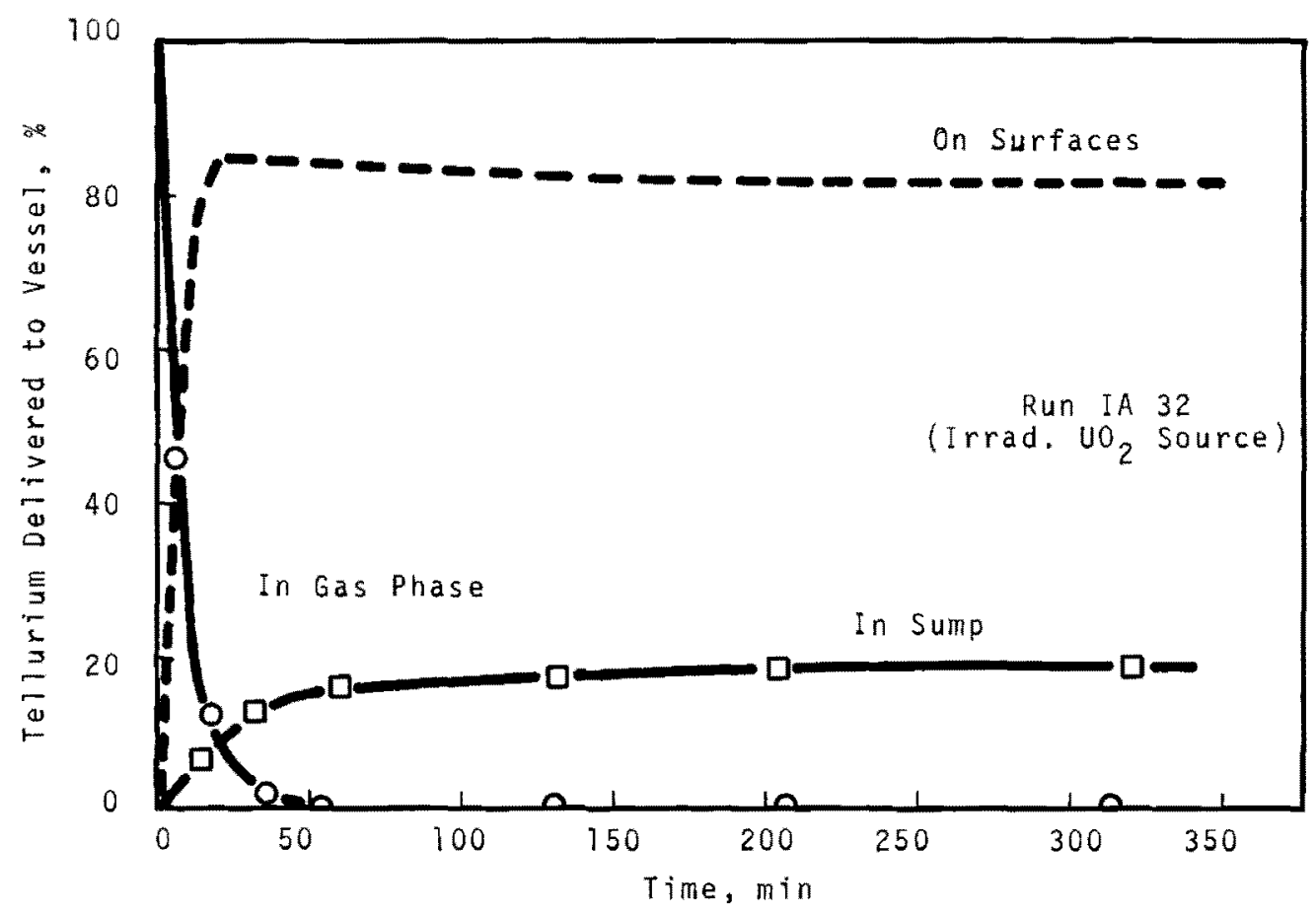

FIGURE B.48. TelZurium Distribution, Series IA

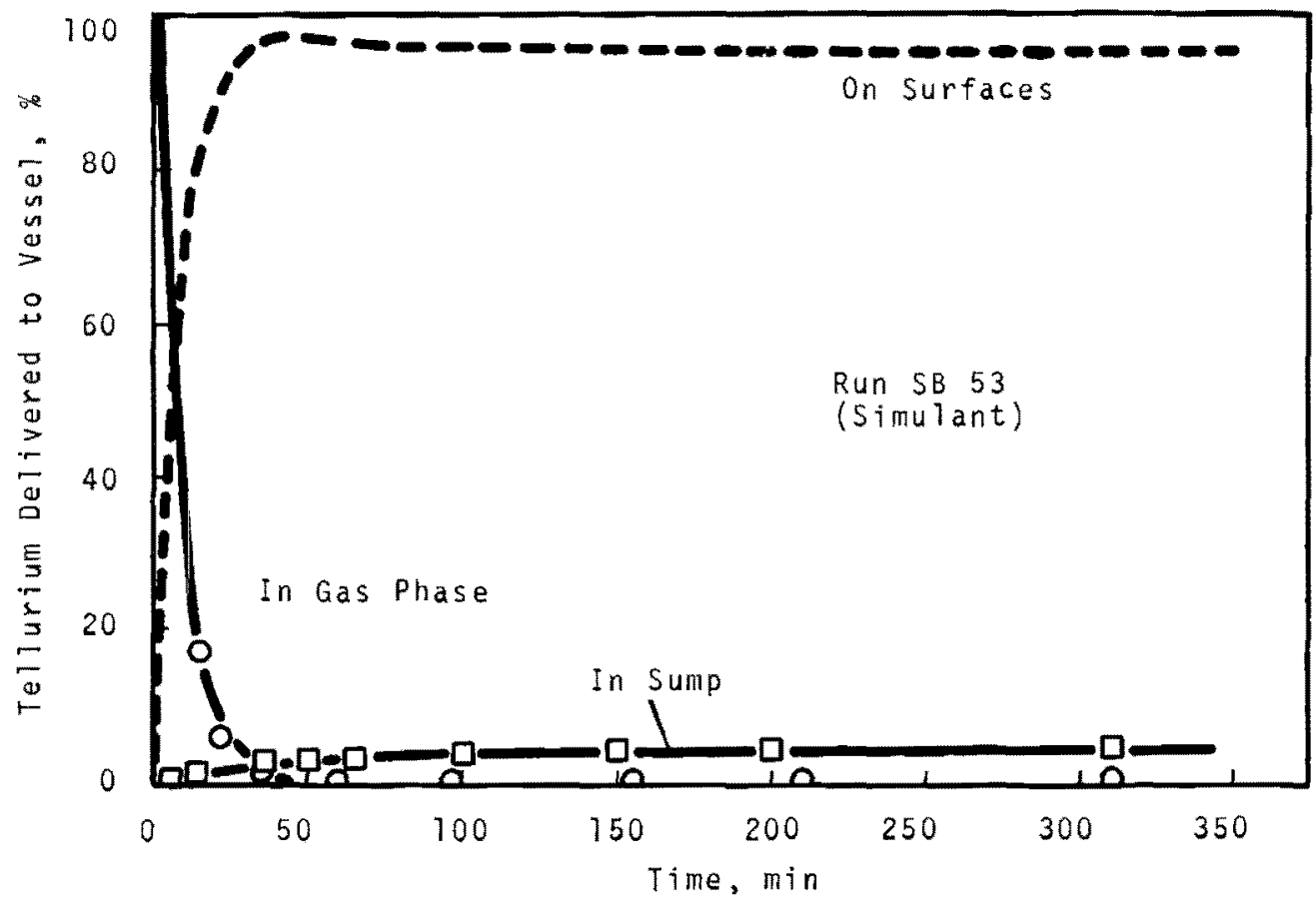

EIGURE B.49. TelZurium Distribution, series SB 


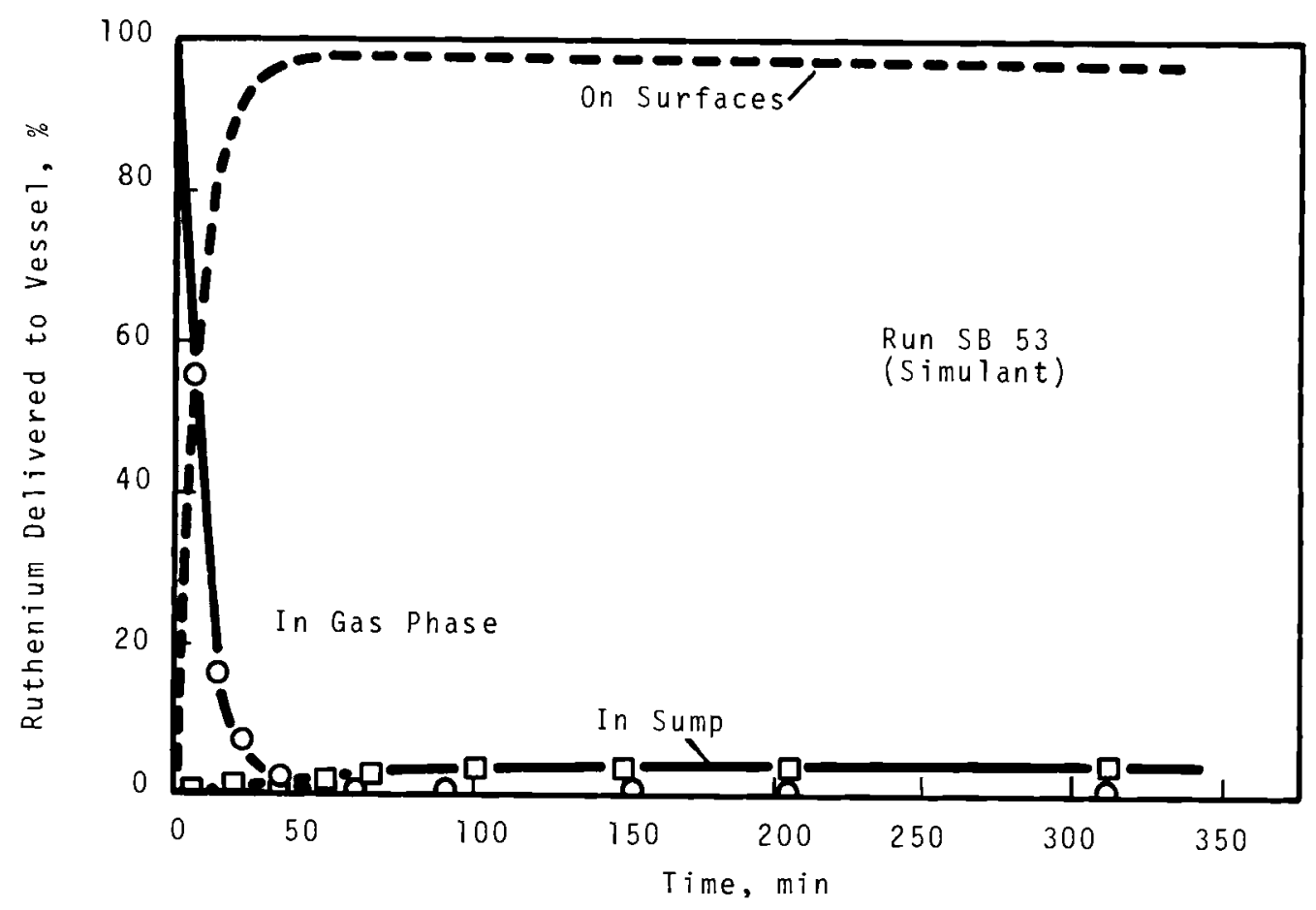

FIGURE B.50. Ruthenium Distribution, Series SB

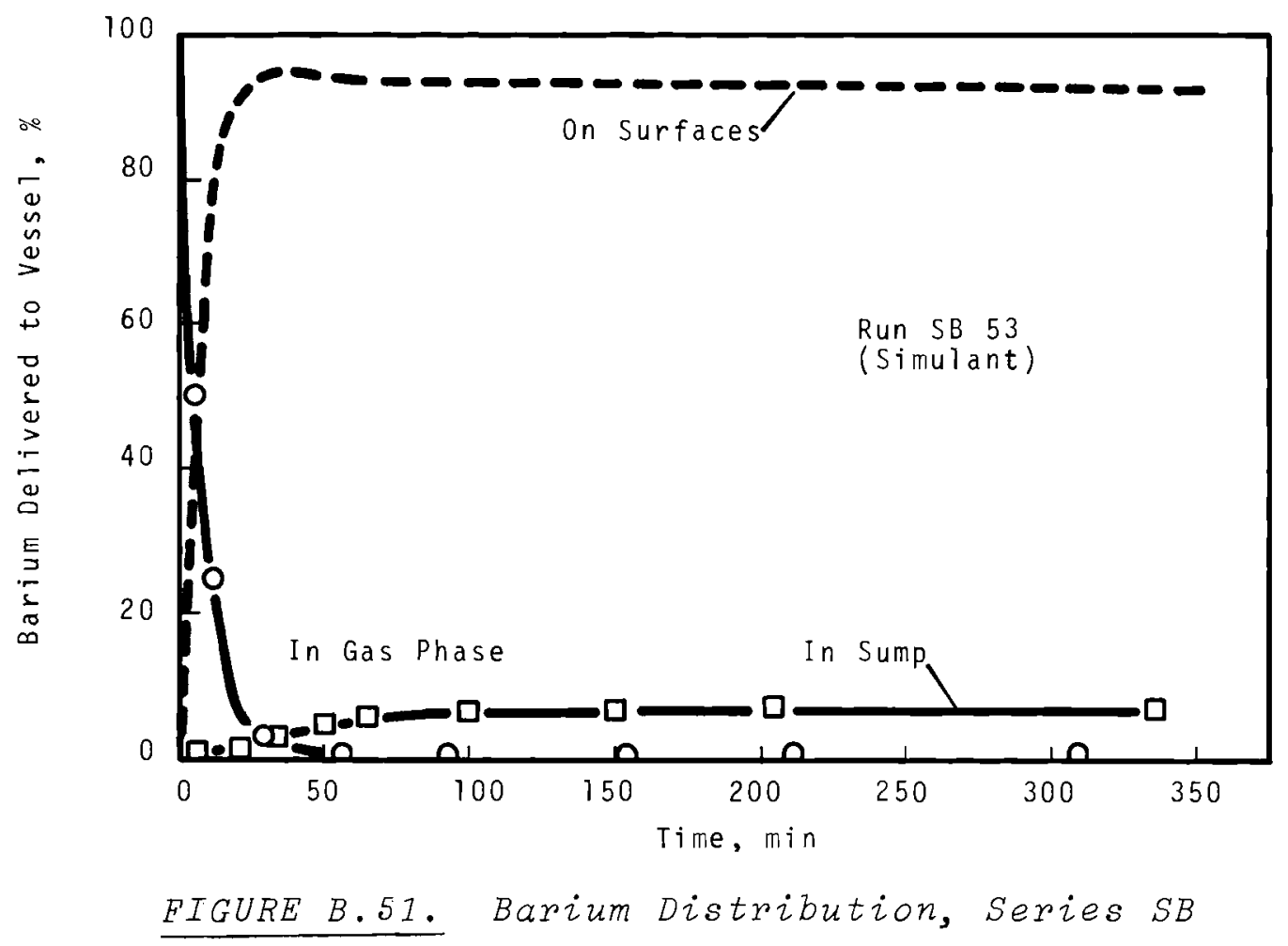




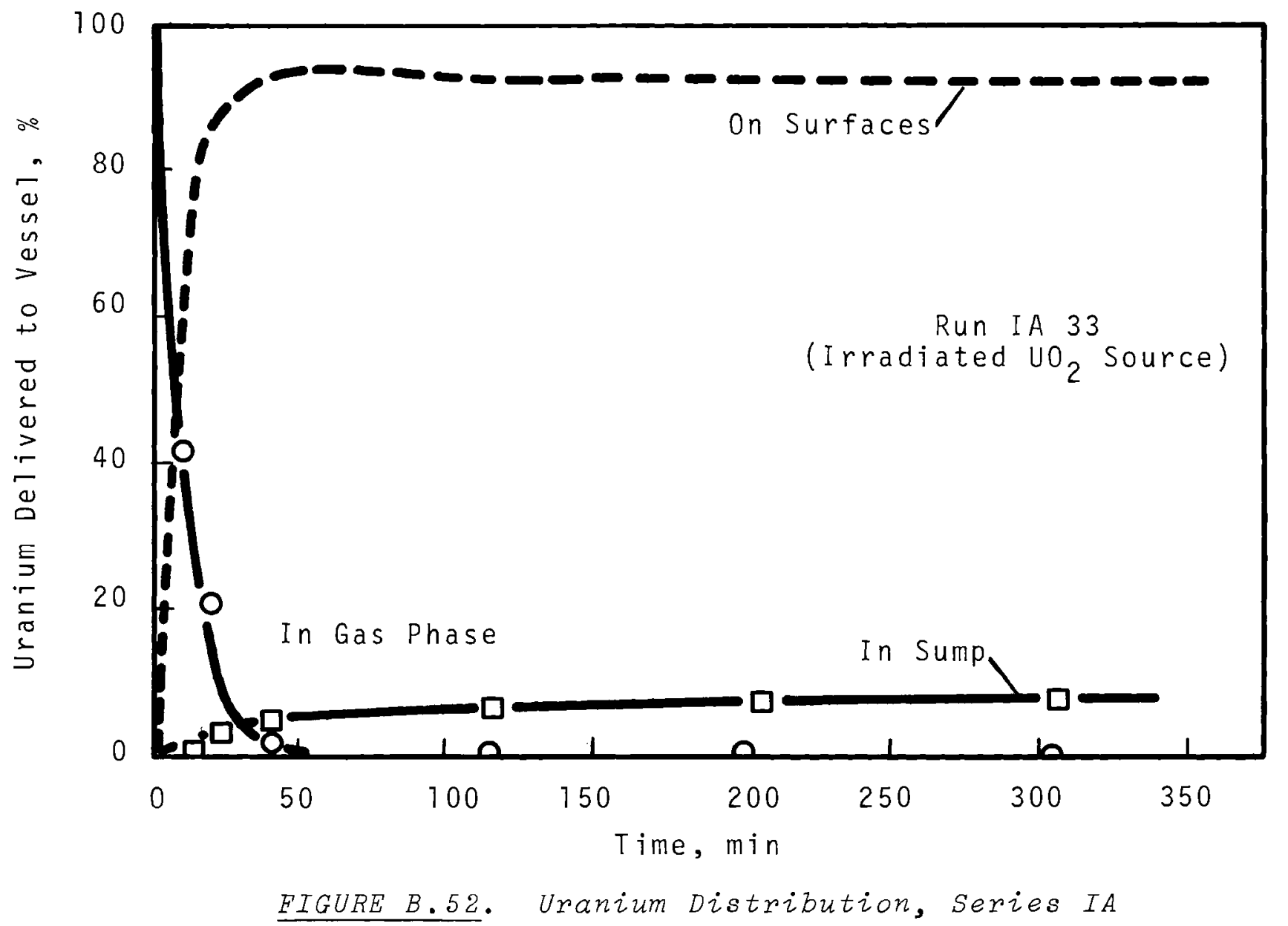

$\underset{y}{ \pm}$

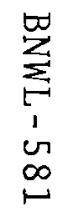


No. of

Copies

7

56

Atomic Energy Commission, Washington

Advisory Committee on Reactor Safeguards

F. R. Fraley

Division of Reactor Development and Technology

R. S. Brodsky (2)

J. W. Crawford

R. L. Ednie

H. L. Hamester

H. G. Hembree

J.A. Lieberman

R. R. Newt on (5)

R. E. Pahler (2)

A. J. Pressesky

I. C. Roberts

E. E. Sinclair

S. A. Szawlewicz

M. J. Whitman

Division of Compliance

L. Kornblith, Jr.

Division of Operational Safety

H. Gilbert

Division of Production

G. B. Pleat

Division of Reactor Standards

M. Bolotsky

E. G. Case (10)

A. B. Holt

Division of Compliance, Region IV

J. W. Flora

R. H. BaII 


$$
\text { Distr }-2
$$

BNWL -581

No. of Copies

1

Atomic Energy Commission

USAEC Technical Representative

H. J. Reynolds

1

Atomic Energy Research Establishment, Harwel1, England

W. J. Megan

2

Atomics International

H. Morewitz

R. Vollmer

1

Auburn University

School of Engineering and

Engineering Experiment Station

G. H. Nix

2

Babcock \& Wilcox Co.

Virginia

R. Wascher

Washington

L. R. Weissert

7

Batte11e Memorial Institute, Columbus
A. R. Duffy
D. L. Morrison (2)
R. L. Ritzman (1)
S. Paprocki (2)
D. N. Sunderman (2)

1 Battelle-Frankfort

Frankfort, Germany

N. Henze 1

1 Bechtel Corporation

R. F. Griffin

1

Brookhaven National Laboratory

A. W. Castleman 
No. of

Copies

1

Canadian General Electric Company

Peterborough, Ontario, Canada

S. Davies

1

Chalk River Nuclear Laboratories

Chalk River, Ontario, Canada

Station 3

F. C. Boyd

G. Hake

1

Chicago Operations office

Atomic Energy Commission

D. M. Gardiner

1

1

1

Dilworth, Secord, Meagher, and Associates Ltd., 4195 Dundas St.

Toronto, Ontario, Canada

I. J. Billington

265 Division of Technical

Information Extension

4

Douglas United Nuclear

T. W. Ambrose

N. R. Miller

J.W. Riches

J. R. Spink

3

General Electric Company,

San Jose

S. Vandenberg

G. E. Wade

E. Zebroski

4

General Electric Corp

APD San Jose

P. Bray

M. Siegler

W. A. Suther 1 and

B. Wolfe 
No. of

Copies

2

1

2

$\frac{\text { Idaho Operations Office }}{\text { Atomic Energy Commission }}$

D. Wi11iams

1 Idaho Nuclear Corporation,

Idaho Falls, Idaho

C. M. Slansky

2

2

1

1

1

1

1

ITT Research Institute

E. Gallagher

T. A. Zaker

O. F. Hil1

G. R. Kiel

1 Los Alamos Scientific Laboratory

J. H. Russe1, K. Division

MPR Associates, Inc.

T. Rockwe11 II I

National Bureau of Standards

C. Muehihause

Naval Ordinance Laboratory

J. proctor

North Carolina State University

M. N. Ozisik

Nuclear Fue1s Services

Atlantic Richfield Hanford Company

R. P. Wischow 
No. of

Copies

13 Oak Ridge National Laboratory

R. E. Adams

C. J. Barton

R. Blanco

W. E. Browning

J. Buchanan

W. B. Cottrel1 (4)

D. Ferguson

M. H. Fontana

S. Friede

C. E. Miller

G. W. Parker

L. F. Parsley

T. H. Rowe

D. B. Trauger (2)

G. M. Watson

4

Oak Ridge Operations Office

Atomic Energy Commission

D. Cope (2)

E. Delaney

W. L. Sma1ley

1 Oregon State University

James G. Knudsen

1

14

\section{cific Gas and Electric Company}

W. Nutting

Phillips Petroleum Company

G. O. Bright

G. F. Brockett

S. Forbes (2)

C. Haire

G. B. Matheny

W. E. Nyer (2)

F. Schroeder (3)

N. K. Sowards

T. R. Wilson (2) 
No. of

Copies

8

Richland Operations office

Atomic Energy Commission

P. G. Holsted

J. Kitchen

C. L. Robinson

R. K. Sharp

A. S. Waterhouse

Technical Information Library

1

San Francisco Operations Office

Lt. Col. J. B. Radcliffe

1

Savannah River Laboratories

A. H. Peters

2

TRW Incorporated

TRW Systems Group

D. B. Langmuir

S. M. Zivi

2

University of California

Institute of Engineering

Research

H. A. Johnson

V. E. Schrock

1

University of Washington

We11s Moulton

5

Westinghouse Electric Co.

E. Beckjord

D. Fletcher

H. Graves

F. M. Heck

R. A. Wiesemann

$75 \quad$ Battelle-Northwest

F. W. Albaugh

R. T. A1 lemann

J. M. Batch

G. E. Benedict

R. H. Bond

L. L. Burger

J. J. Cadwe11 
Battelle-Northwest (contd)

L. F. Coleman

D. L. Condotta

F. G. Daws on

D. R. de Halas

J. R. Fishbaugher

R. F. Foster

J. C. Fox

J. J. Fuquay

W. A. Haney

H. Harty

R. K. Hilliard (30)

J. F. Honstead

R. T. Jaske

R. L. Junkins

A. R. Keene

C. E. Linderoth

J. D. McCormack

A. J. McElfresh

J. M. Nielson

R. E. Nightingale

H. M. Parker

R. S. Paul

L. T. Pedersen

A. K. Postma

D. L. Reid

W. D. Richmond

G. J. Rogers

L. C. Schwendiman

G. A. Sehmel

D. E. Simpson

J. C. Spanner

W. C. Townsend

E. E. Voiland

R. G. Wheeler

N. P. Wilburn

N. G. Wittenbrock

M. E. Witherspoon

D. C. Worlton

Patent Section (2)

Technical Information Files

Technical Publications (1) 


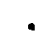

, 